



\section{Evaluatie Regeling brede weersverzekering}

Petra Berkhout, Marcel van Asseldonk, Ruud van der Meer, Harold van der Meulen en Huib Silvis

Dit onderzoek is uitgevoerd door Wageningen Economic Research in opdracht van en gefinancierd door het ministerie van Economische Zaken.

Wageningen Economic Research

Wageningen, september 2016

RAPPORT

2016-070

ISBN 978-94-6257-934-7 
Berkhout, P., M. Van Asseldonk, R.W. van der Meer, H.A.B. van der Meulen en H.J. Silvis, 2016. Evaluatie Regeling brede weersverzekering. Wageningen, Wageningen Economic Research, Rapport 2016-070. 60 blz.; 9 fig.; 13 tab.; 26 ref.

In de open teelten van de agrarische sector zijn er weinig mogelijkheden om risico's die weersinvloeden kunnen hebben op de productie te voorkomen. Schade als gevolg van een extreme weersomstandigheid (zoals hevige regenval of hagel) kan echter een grote invloed hebben op de financiële positie van de bedrijven en de sector als geheel.

Vóór 2002 sprong de overheid geregeld bij in het vergoeden van schade als gevolg van extreme weersomstandigheden. Om een commerciële markt te creëren stimuleert de overheid tegenwoordig via een premiesubsidie deelname aan een brede weersverzekering. Dit rapport evalueert ten eerste of deze premiesubsidie heeft geleid tot een commercieel aantrekkelijke verzekering en ten tweede of deze subsidie ertoe heeft geleid dat het aantal en de omvang van de verzoeken tot schadevergoeding is verminderd. Het antwoord op de eerste vraag is nee; het antwoord op de tweede vraag is moeilijk objectief vast te stellen op basis van empirische gegevens.

The agricultural sector has limited opportunities to avoid risks of weather events for open field crops. However, damage caused by extreme weather conditions (such as heavy rain or hail) can have a major impact on the financial position of the farms and the whole agricultural sector.

Before 2002 the Dutch government regularly compensated damage caused by extreme weather events. Nowadays the government encourages farmers to participate in a weather insurance scheme by granting a premium subsidy, thus trying to create a commercial market for weather insurances. This report evaluates the premium subsidy. The core questions are first if the subsidy has led to a commercially attractive weather insurance scheme and second if the premium subsidy has reduced the number of requests for compensation and the amount. The answer to the first question is no; due to a lack of empirical evidence, there is no clear objective answer to the second question.

Trefwoorden: brede weersverzekering, subsidie, risico, oogstsschadevergoeding, evaluatie

Dit rapport is gratis te downloaden op http://dx.doi.org/10.18174/390180 of op www.wur.nl/economic-research (onder Wageningen Economic Research publicaties).

(C) 2016 Wageningen Economic Research

Postbus 29703, 2502 LS Den Haag, T 07033583 30, E communications.ssg@wur.nl, www.wur.nl/economic-research. Wageningen Economic Research is onderdeel van Wageningen University \& Research.

\section{(cc) BY-NC}

Wageningen Economic Research hanteert voor haar rapporten een Creative Commons Naamsvermelding 3.0 Nederland licentie.

(C) Wageningen Economic Research, onderdeel van Stichting Wageningen Research, 2016

De gebruiker mag het werk kopiëren, verspreiden en doorgeven en afgeleide werken maken. Materiaal van derden waarvan in het werk gebruik is gemaakt en waarop intellectuele eigendomsrechten berusten, mogen niet zonder voorafgaande toestemming van derden gebruikt worden. De gebruiker dient bij het werk de door de maker of de licentiegever aangegeven naam te vermelden, maar niet zodanig dat de indruk gewekt wordt dat zij daarmee instemmen met het werk van de gebruiker of het gebruik van het werk. De gebruiker mag het werk niet voor commerciële doeleinden gebruiken.

Wageningen Economic Research aanvaardt geen aansprakelijkheid voor eventuele schade voortvloeiend uit het gebruik van de resultaten van dit onderzoek of de toepassing van de adviezen.

Wageningen Economic Research is ISO 9001:2008 gecertificeerd.

Wageningen Economic Research 2016-070 | Projectcode 2282500138

Foto omslag: Shutterstock 


\section{Inhoud}

Woord vooraf $\quad 5$

$\begin{array}{ll}\text { Samenvatting } & 6\end{array}$

S.1 Hoofdvragen $\quad 6$

S.2 Bereik, doeltreffendheid, doelmatigheid 6

$\begin{array}{lll}\mathrm{S} .3 & \text { Aanpak } & 7\end{array}$

$\begin{array}{ll}\text { Summary } & 8\end{array}$

$\begin{array}{lll}\text { S.1 Key questions } & 8\end{array}$

$\begin{array}{lll}\text { S.2 Scope, efficacy, efficiency } & 8\end{array}$

$\begin{array}{lll}\text { S.3 Approach } & 9\end{array}$

1

\section{Inleiding}

1.1 Aanleiding $\quad 10$

$\begin{array}{lll}1.2 & \text { Doelstelling } & 10\end{array}$

$\begin{array}{lll}1.3 & \text { Aanpak } & 11\end{array}$

1.4 Opbouw van het rapport $\quad 12$

2

$\begin{array}{lr}\text { Beleidstheorie } & 14\end{array}$

$\begin{array}{lll}2.1 & \text { Inleiding } & 14\end{array}$

$\begin{array}{lll}2.2 & \text { Risico's en risicobeheer } & 14\end{array}$

$\begin{array}{lll}2.3 & \text { Regeling brede weersverzekering } & 16\end{array}$

$3 \quad$ Bereik van de Regeling $\quad 18$

$\begin{array}{lll}3.1 & \text { Inleiding } & 18\end{array}$

3.2 Aantal bedrijven met een brede weersverzekering $\quad 18$

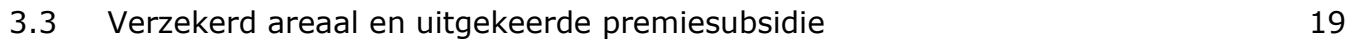

$\begin{array}{lll}3.4 & 3.4 \text { Structuurkenmerken deelnemers BWV } & 21\end{array}$

3.5 Conclusies op basis van de analyse van de RVO.nl-data 23

4

$\begin{array}{ll}\text { Doeltreffendheid } & 25\end{array}$

$4.1 \quad$ Inleiding $\quad 25$

4.2 Bevindingen op basis van de enquête $\quad 25$

4.3 Bevindingen op basis van de interviews 29

4.4 Conclusies op basis van de enquête en de interviews 30

5 Doelmatigheid $\quad 31$

5.1 Inleiding 31

5.2 Aanbieders van een brede weersverzekering 31

$\begin{array}{lll}5.3 & \text { Procedure } & 32\end{array}$

5.4 Uitvoeringskosten $\quad 33$

$\begin{array}{lll}5.5 & \text { Beoordeling } & 34\end{array}$

5.6 Vergelijking met andere EU-lidstaten $\quad 34$

$\begin{array}{lll}5.7 & \text { Conclusies } & 36\end{array}$ 
$\begin{array}{lll}6.1 & \text { Inleiding } & 37\end{array}$

$\begin{array}{lll}6.2 & \text { Oogstschadevergoedingen in het verleden } & 37\end{array}$

6.3 Oogstschade periode 2009-2016 39

$\begin{array}{lll}6.4 & \text { Conclusies } & 40\end{array}$

$\begin{array}{lll}7.1 & \text { Synthese } & 41\end{array}$

$\begin{array}{lll}7.2 & \text { Discussie } & 43\end{array}$

$\begin{array}{lll}7.3 & \text { Aanbevelingen } & 44\end{array}$

$\begin{array}{ll}\text { Literatuur en websites } & 45\end{array}$

$\begin{array}{lll}\text { Bijlage } 1 & \text { Agrarische verzekeringen } & 47\end{array}$

Bijlage 2 Bedrijven met en zonder BWV 49

Bijlage 3 Enquête agrarische ondernemers $\quad 52$

$\begin{array}{lll}\text { Bijlage } 4 & \text { Geïnterviewde personen } & 58\end{array}$ 


\section{Woord vooraf}

In de open teelten van de agrarische sector zijn er weinig mogelijkheden om risico's die weersinvloeden kunnen hebben op de productie te voorkomen. Schade als gevolg van een extreme weersomstandigheid (zoals hevige regenval of hagel) kan echter een grote invloed hebben op de financiële positie van de bedrijven en de sector als geheel. Dat bleek zelfs tijdens dit onderzoek in juni 2016, toen veel bedrijven in de land- en tuinbouw schade ondervonden van hevige regenval en hagelbuien.

Vóór 2002 sprong de overheid geregeld bij in het vergoeden van schade door extreme weersomstandigheden. Om een commerciële markt te creëren stimuleert de overheid tegenwoordig via een premiesubsidie deelname aan een brede weersverzekering. Deze evaluatie - in opdracht van het ministerie van Economische Zaken (EZ) - draait om twee vragen. Ten eerste of de premiesubsidie heeft geleid tot een commercieel aantrekkelijke verzekering en ten tweede of de premiesubsidie ertoe heeft geleid dat het aantal en de omvang van de schadeverzoeken is verminderd.

De evaluatie is voorzien in de Rijksbegroting 2016 en grotendeels uitgevoerd in de periode januari mei 2016. De weersoverlast in juni 2016 heeft geen invloed gehad op de resultaten van het onderzoek, die voor juni 2016 al beschikbaar waren. Wel is op enkele plaatsen in het rapport feitelijke informatie (onder andere over aantallen deelnemers in 2016) geactualiseerd naar aanleiding van de schade en overlast als gevolg van de regen en hagel in juni, zodat lezers over de meest recente informatie beschikken.

Dit onderzoek had niet kunnen plaatsvinden zonder de medewerking van geënquêteerde agrarische ondernemers en van de gesprekspartners bij verzekeraars, landbouworganisaties en de Rijksdienst voor Ondernemend Nederland (RVO.nl). We danken hen allen hartelijk voor hun tijd en inzet.

Het onderzoek is begeleid door een commissie van het ministerie van Economische Zaken, onder voorzitterschap van Puck Bonnier. De overige leden van de begeleidingscommissie waren René ten Hove, Pytrik Altena, Kees van Drunen en Jan Dam. Ook hen bedanken we voor hun betrokkenheid.

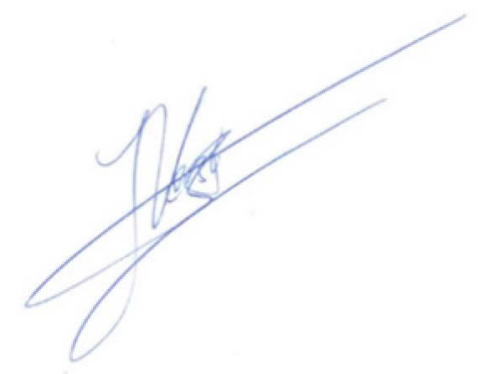

Prof.dr.ir. Jack (J.G.A.J.) van der Vorst

Algemeen directeur

Social Sciences Group

Wageningen University \& Research 


\section{Samenvatting}

\section{S.1 Hoofdvragen}

De evaluatie van de Regeling brede weersverzekering draait om twee hoofdvragen, namelijk:

1. Is er aan het einde van de looptijd van de Regeling brede weersverzekering voor de periode 20102014 een commercieel aantrekkelijke verzekering voor de verzekeraar en voor de verzekerden, zonder overheidssteun?

2. In welke mate heeft de Regeling brede weersverzekering ertoe geleid dat het aantal en de omvang van de verzoeken tot schadevergoedingen aan het ministerie van $\mathrm{EZ}$ is verminderd?

Het antwoord op de eerste vraag is nee. Deze conclusie is bevestigd door zowel telers en landbouworganisaties als door verzekeraars. Aan het einde van de looptijd van de eerste regeling waren er te weinig deelnemers om een commercieel aantrekkelijke verzekering in de markt te zetten. Ondernemers geven als belangrijkste redenen om niet deel te nemen aan dat de premie en het eigen risico van de verzekering te hoog zijn en de dekking te beperkt.

Het antwoord op de tweede vraag is moeilijk objectief vast te stellen. Immers, de verzekering dekt extreem weer af dat per definitie niet frequent voorkomt. Echter, in de korte looptijd sinds openstelling van de Regeling brede weersverzekering hebben zich een aantal extreme weersituaties voorgedaan, waarbij vanuit de sectorvertegenwoordigers geen verzoek is ingediend voor een ad-hoc publieke schadeloosstelling. Het ministerie van Economische Zaken had een heldere boodschap en kon wijzen op de mogelijkheid van de Regeling brede weersverzekering met ondersteuning van de landbouworganisaties. De meest recente teeltschade van juni 2016 heeft wel geleid tot een verzoek om tegemoetkoming, maar tot op heden (juli 2016) is het ministerie van EZ hier niet in meegegaan.

\section{S.2 Bereik, doeltreffendheid, doelmatigheid}

De aannames van de overheid bij het opstellen van de Regeling brede weersverzekering dat in een periode van vier jaar alle openteeltondernemers een brede weersverzekering (BWV) zouden hebben afgesloten en iedere deelnemer zijn gehele areaal met alle gewassen zou verzekeren, zijn niet bewaarheid. Daarmee blijft het bereik van de Regeling brede weersverzekering achter bij het gestelde doel.

De belangrijkste reden voor ondernemers om een BWV af te sluiten is dat dit de enige manier is om vanuit de overheid bij verzekerbare gewasschade nog een vergoeding te krijgen. De mogelijkheid om specifieke gewassen te verzekeren en het feit dat de subsidie sinds 2015 direct in mindering wordt gebracht op de te betalen premie, zijn eveneens belangrijke beweegredenen voor het afsluiten van de verzekering.

Het doel om commercieel aantrekkelijke verzekeringen voor de verzekeraar en voor de agrarische ondernemingen tot stand te brengen is niet bereikt. Het doel om het aantal verzoeken tot schadevergoeding aan het ministerie van EZ te verminderen is wel gehaald, uitgezonderd de meest recente teeltschade in juni 2016.

De indruk is dat de uitvoering door de Rijksdienst voor Ondernemend Nederland (RVO.nl) van de Regeling brede weersverzekering doelmatig gebeurt. Voor een belangrijk deel is dit toe te schrijven aan de goede samenwerking van RVO.nl met de aanbieders van een BWV én aan de mogelijkheid om de Regeling brede weersverzekering administratief samen te laten lopen met de Gecombineerde opgave (de jaarlijkse aanlevering van gegevens door agrarisch ondernemers aan RVO.nl). 
De kosten voor de overheid in geval er geen Regeling brede weersverzekering zou zijn geweest in de periode 2010-2014, worden geschat op $46 \mathrm{mln}$. euro, gebaseerd op de vorstschade in de fruitteelt in 2012. Dit was een voorval waarbij in het verleden in soortgelijke gevallen tegemoetkoming werd verleend. Ter vergelijking, de jaarlijkse premiesubsidie bedroeg 4,8 mln. euro in 2012 . De geschatte uit te betalen ad-hocschadevergoeding is ook aanzienlijk meer - ongeveer het dubbele - dan de verstrekte premiesubsidie in de periode 2010-2014 (23 mln. euro).

Een andere benadering is om de jaarlijkse premiesubsidie van 7,8 m/n. euro in 2015 te vergelijken met de gemiddelde ad-hoctegemoetkoming voorafgaande aan de openstelling. Deze bedroeg gemiddeld nominaal circa $12 \mathrm{mln}$. euro per jaar (totaal circa $429 \mathrm{mln}$. euro voor een tijdsbestek van 35 jaar). Ook in dat perspectief is de Regeling brede weersverzekering doelmatig geweest.

\section{S.3 Aanpak}

De aanpak van de evaluatie bestond onder meer uit het verzamelen van data via een enquête onder akkerbouwers, fruittelers en veehouders die snijmais telen, uit interviews met belanghebbenden aan zowel de aanbod- als vraagzijde, en uit een scenarioanalyse. In meer detail gaat het om de volgende zes stappen (Figuur S.1.):

A. Bestuderen van de informatie van RVO.nl, aangevuld met bevindingen van stakeholders, om een beeld te krijgen van de uitvoeringskosten van de regeling, de kwaliteit van de uitvoering en de klanttevredenheid van derden

B. Stakeholderanalyse op basis van zeven diepte-interviews om (gevoelige) informatie te verzamelen over vraag (LTO, NAV en NFO) en aanbod (Achmea, AgriVer, OFH en Vereinigte Hagel)

C. Analyse ontwikkelingen aanbodzijde op basis van websites en interviews met verzekeraars

D. Analyse preferentie en perceptie telers op basis van enquête

E. Analyse structuurkenmerken gebruikers versus niet-gebruikers

F. Scenarioanalyse extreme weersituaties.

De gecombineerde resultaten van deze deelactiviteiten geven inzicht in het bereik, de doeltreffendheid en de doelmatigheid van de Regeling.

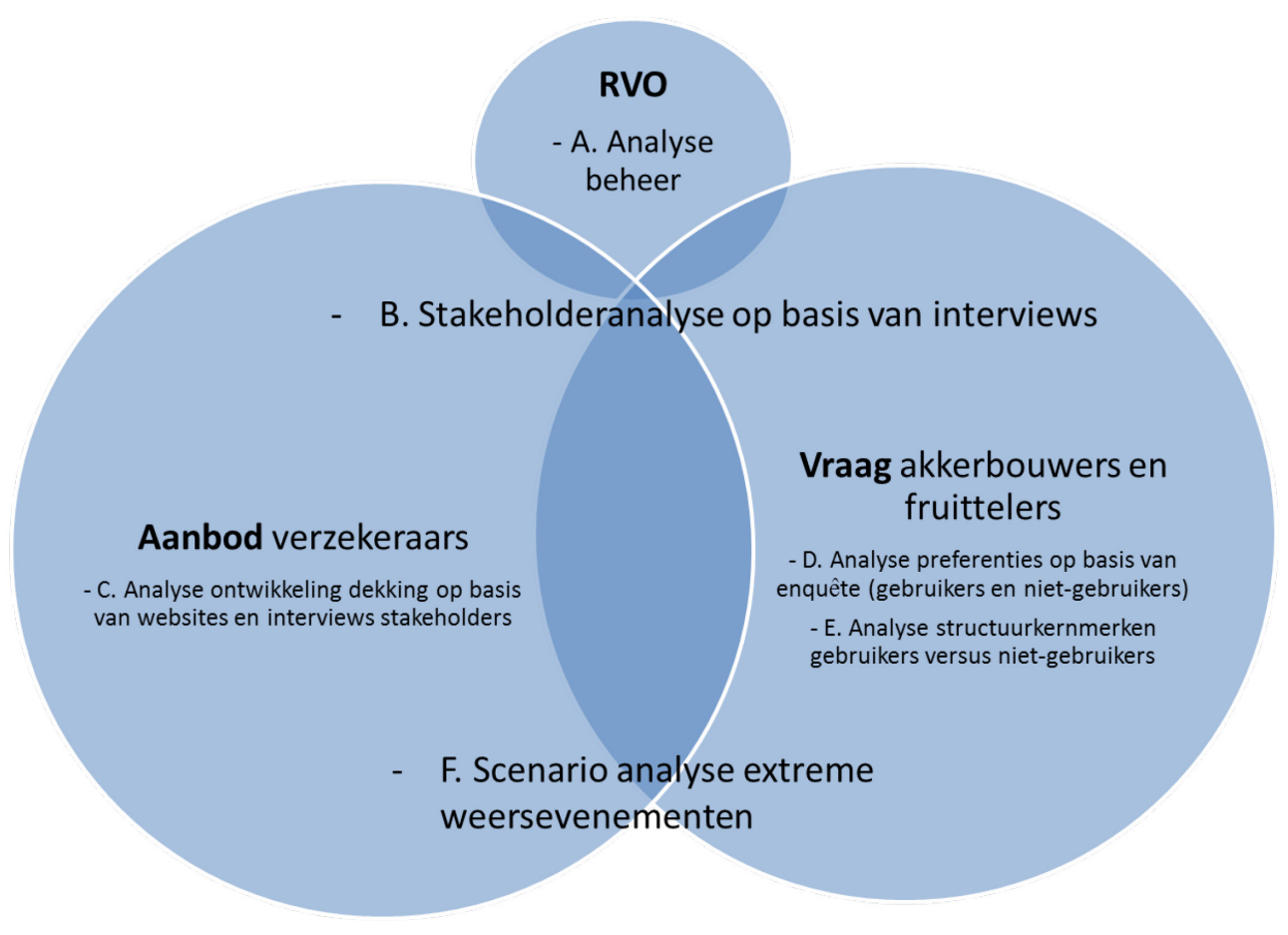

Figuur S.1 Activiteiten voor de evaluatie 


\section{Summary}

\section{S.1 Key questions}

The evaluation of the Regeling brede weersverzekering ('Scheme for broad insurance for bad weather') revolves around two key questions, namely:

1. At the end of the validity of the Scheme for broad insurance for bad weather during the period 2010 to 2014, is there a commercially attractive insurance policy for the insurer and insured parties that does not involve government funding?

2. To what extent has the Scheme resulted in a decrease of the number, and narrowing of the scope, of the claims for damages submitted to the Ministry of Economic Affairs?

The answer to the first question is 'no'. This conclusion has been corroborated by growers, agricultural organisations and insurers. At the end of the life of the first scheme, there were too few participants to market a commercially attractive insurance policy. Entrepreneurs stated the limited cover and too high costs of the insurance's premium and excess as the most significant reasons not to participate.

As the insurance covers extreme weather, a phenomenon that by definition is uncommon, it is difficult to provide an objective answer to the second question. There have, however, been a number of extreme weather situations in the short period since the Scheme was made available, but none of the sector representatives have submitted a claim for an ad hoc, public compensation. The Dutch Ministry of Economic Affairs had a clear message, highlighting the availability of the Scheme with support of agricultural organisations. While the most recent crop damage in June 2016 did result in an application for relief, this has to date (July 2016) not been accepted by the Ministry of Economic Affairs.

\section{S.2 Scope, efficacy, efficiency}

The assumptions made by the government when designing the Scheme have not materialised. These assumptions were that, in a four-year period, all open cultivation growers would have taken out a broad insurance for bad weather and that every participant would have insured all crops across his or her entire area. As a result, the scope of the Scheme remains inferior to the objective set.

The most important reason that entrepreneurs take out a broad insurance for bad weather is that this represents the sole means of receiving compensation from the government for insurable crop damage. In addition to this, the option to insure specific crops and the fact that, since 2015 , the funding has been deducted from the premiums to be paid are important motives to take out the insurance.

The goal of creating commercially attractive insurance policies for insurers and agricultural entrepreneurs has not been achieved. However, with the exception of the most recent crop damage in June 2016, the goal of decreasing the number of claims for damages to the Ministry of Economic Affairs has been met.

The Netherlands Enterprise Agency (RVO.nl) appears to be implementing the Scheme efficiently. This is predominantly thanks to the effective collaboration between the Agency and parties offering a broad insurance policy for bad weather, coupled with the fact that the Scheme can be administered in conjunction with the 'Gecombineerde opgave,' a scheme in which agricultural entrepreneurs submit data to the Agency on a yearly basis.

Based on the frost damage to fruit crops in 2012, the costs to the government if there had been no Scheme from 2010 to 2014 are estimated to amount to 46 million EUR. In the past, relief was provided in incidents of a similar nature. In comparison, in 2012 the annual premium funding 
amounted to 4.8 million EUR. The estimated ad hoc damages compensation due is also considerably higher - around twice the amount - than the premium funding paid out in the period 2010 to 2014, amounting to 23 million EUR.

A different approach is to compare the annual premium funding of 7.8 million EUR in 2015 with the average ad hoc relief prior to the opening of the Scheme. On average, this amounted nominally to around 12 million EUR per annum (with a total of approximately 429 million EUR for a time frame of 35 years). In this light, too, the Scheme has been effective.

\section{S.3 Approach}

The evaluation was conducted on the basis of data gathered via a survey among arable farmers, fruit growers and livestock holders who grow green maize; data from interviews with interested parties on the supply and demand side; and data from a scenario analysis. Figure S.1 provides more detail on the following six steps:

A. Studying information from the Netherlands Enterprise Agency, supplemented by findings from stakeholders, in order to gain a picture of the costs of implementing the Scheme, the quality of implementation and customer satisfaction as reported by third parties.

B. Stakeholder analysis on the basis of seven in-depth interviews in order to gather sensitive information on supply (Achmea, AgriVer, OFH and Vereinigte Hagel VVaG) and demand (LTO, NAV and NFO).

C. Analysis of developments on the supply side on the basis of websites and interviews with insurers

D. Analysis of the preference and perception of growers on the basis of a survey

E. Analysis of structural characteristics of participants versus non-participants

F. Scenario analysis of extreme weather situations

The combined results of these partial activities provide information on the scope, efficacy and efficiency of the Scheme.

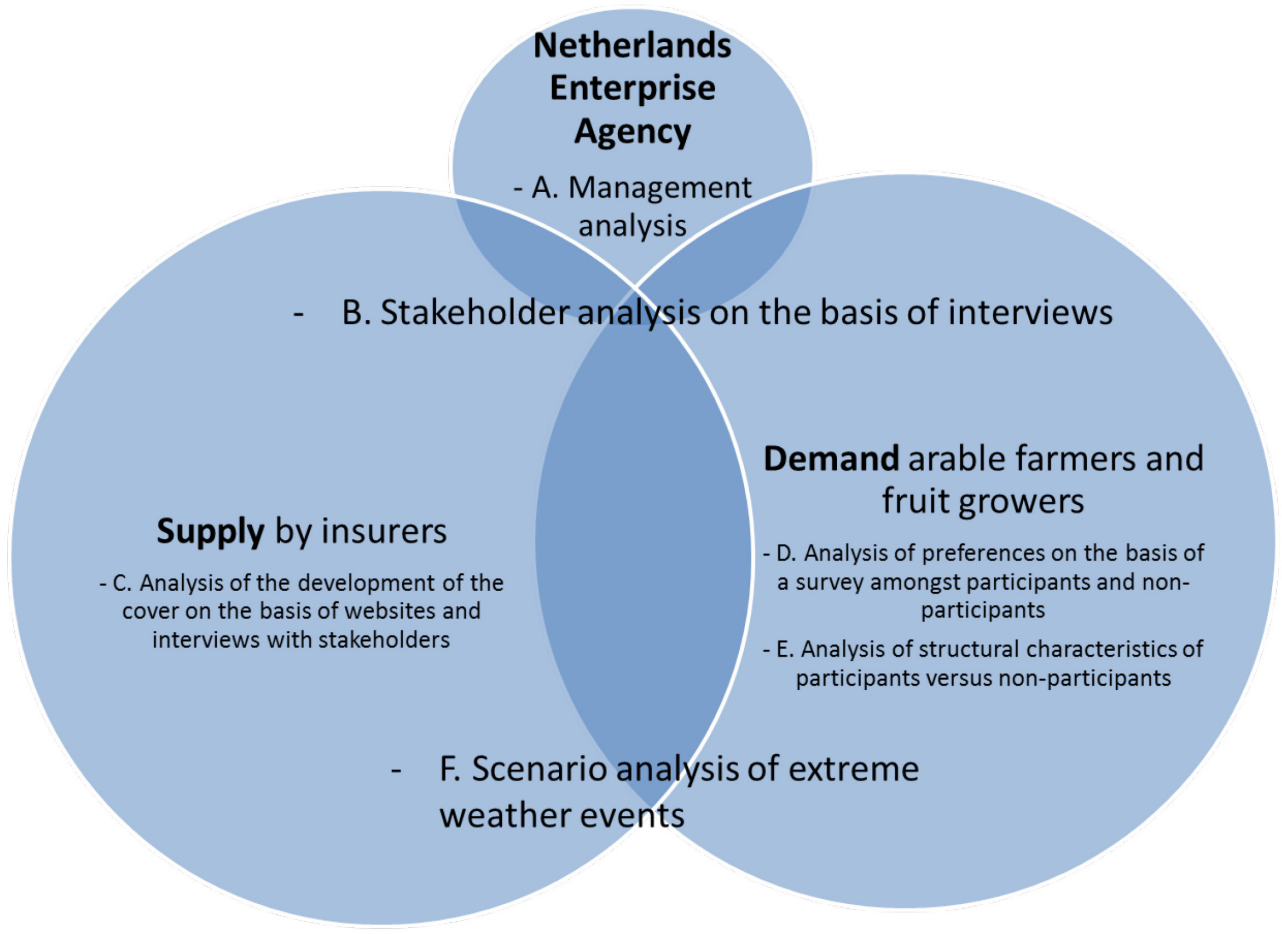

Figure S.1 Activities for evaluation purposes 


\section{$1 \quad$ Inleiding}

\section{$1.1 \quad$ Aanleiding}

De vaststelling in 2010 van de Regeling brede weersverzekering, ondersteund met premiesubsidie via Verordening 73/2009 van het Gemeenschappelijk landbouwbeleid, kan als sluitpost worden gezien van een lang traject. Vóór 2002 sprong de overheid op ad-hocbasis bij in het vergoeden van onverzekerbare schade door extreme weersomstandigheden. In 2002 heeft de overheid ingezet op een ex-ante regeling met een grotere eigen verantwoordelijkheid van de sector en de ondernemers voor het dragen van de schade, bijvoorbeeld in de vorm van een verzekering. In overleg met de sector is in 2009 een Regeling brede weersverzekering (hierna Regeling) opgezet. Door de premie te subsidiëren zou een brede weersverzekering (BWV) toegankelijk worden voor alle open teelten en alle weersrisico's afdekken.

Een BWV is een bijzondere agrarische verzekering, waarvan de voorlopers niet succesvol zijn geweest (zie Bijlage 1). Vanaf 2010 is een BWV aangeboden door vier aanbieders; een van de aanbieders is in 2012 - na twee jaar - gestopt vanwege de geringe deelname. De belangstelling voor de BWV was in de opstartjaren meteen groot onder fruittelers. Onder akkerbouwers, vollegrondsgroentetelers, bloembollentelers en boomkwekers was die aanvankelijk beperkt, maar in recente jaren is de deelname gegroeid.

\subsection{Doelstelling}

Met de premiesubsidie voor een BWV beoogt de overheid deelname van agrariërs aan de private verzekering te stimuleren en zo een markt te creëren. Bij de start in 2010 was de gedachte dat een periode van vier jaar voldoende zou zijn om genoeg deelnemers te bereiken, maar de deelname aan de BWV in de opstartfase 2010-2013 was beperkt. Deze periode is met een jaar verlengd (2014), omdat er geld beschikbaar was door uitstel van de start van het nieuwe GLB naar 2015. Omdat het aantal deelnemers nog steeds onvoldoende was, is de premiesubsidie voortgezet in een Regeling $B W V$-2 die de periode 2015-2020 beslaat.

Deze evaluatie in opdracht van het ministerie van EZ, voorzien in de Rijksbegroting 2016

(Rijksbegroting 2016:240), is de eerste evaluatie van de Regeling en beoogt inzicht te geven in het bereik, de doeltreffendheid en de doelmatigheid van de Regeling. ${ }^{1}$

Figuur 1.1 presenteert de beschikbare monitoring en effectmeting (M\&E) informatie van de Regeling, zoals opgesteld door het ministerie van EZ.

De cirkel bestaat uit vier segmenten:

- middelen de middelen die het beleid en RVO.nl inzetten voor het uitvoeren van de Regeling

- activiteiten activiteiten die RVO.nl en derden uitvoeren voor de Regeling

- resultaten resultaten bij de doelgroep van de Regeling

- effecten effecten bij de doelgroep.

${ }^{1}$ In 2007 is een evaluatie uitgevoerd van de zogenaamde Regenschadeverzekering (Bureau Bartels, 2007), een van de voorlopers van de BWV. 
$2^{\mathrm{e}}+3^{\mathrm{e}}$ orde:

- Versterken concurrentiekracht (artikel 16

EZ-begroting)

$1^{\mathrm{e}}$ orde effect: overheidsdoel

- Aanbod van commercieel aantrekkelijke verzekeringen voor de verzekeraar en voor de agrarische ondernemingen

- Geen/ minder verzoeken (in aantallen en budget) tot schadevergoeding aan het ministerie van EZ
- $26 \mathrm{mln}$. euro voor premiesubsidie in de periode 2010-2014

- Wet- en regelgeving
- Groei aantal deelnemers

- Groei waarde omvang van verzekeringen

- Groei verzekerd oppervlak

- Met name risicovolle teelten worden verzekerd

- Verzoeken om schadevergoeding worden niet meer gehonoreerd.
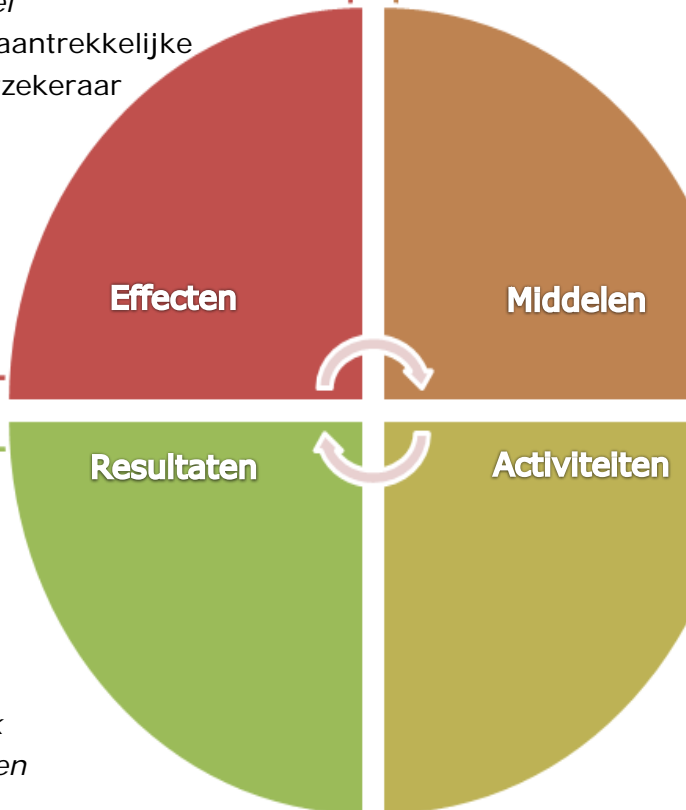

- Opstellen kaders brede weersverzekering t.b.v. regelgeving

- Erkenning verzekeraars door RVO

- Beoordeling aanvragen landbouwers door RVO

- Betaling subsidie door RVO

Figuur 1.1 M\&E resultaatcirkel voor de Regeling (Monitoring \& Effectmeting) Bron: $E Z$ (2016).

De hoofdvragen voor de evaluatie zijn:

1. Is er aan het einde van de looptijd van de Regeling brede weersverzekering voor de periode 20102014 een commercieel aantrekkelijke verzekering voor de verzekeraar en voor de verzekerden, zonder overheidssteun?

2. In welke mate heeft de Regeling brede weersverzekering ertoe geleid dat het aantal en de omvang van de verzoeken tot schadevergoedingen is verminderd?

Deze vragen worden beantwoord in de zin van doelbereik, doeltreffendheid en doelmatigheid en in de context van:

- In welke mate speelde de regeling in op een reëel bestaande marktimperfectie (legitimiteit)?

- In hoeverre was de regeling een geschikt instrument om bij te dragen aan het oplossen van deze imperfectie?

- Hadden effecten met minder middelen kunnen worden gerealiseerd?

- Zijn er vergelijkbare situaties in andere lidstaten? Zo ja, draaien die zonder subsidie of steun?

- Is het uitvoeringsproces van de regeling doelmatig vormgegeven?

- Wat zijn de (gekwantificeerde) uitvoeringskosten ten opzichte van de verstrekte subsidie voor RVO.nl ten opzichte van de verstrekte subsidie en hoe ontwikkelen deze zich in de tijd?

- Wat is de kwaliteit van de uitvoering door RVO.nl en derden (bijvoorbeeld klanttevredenheid,

- risicoanalyse, controlesystematiek en onregelmatigheden)?

- Wat zijn de administratieve lasten voor een deelnemer aan de regeling?

- Geef een inschatting van de 'total cost of ownership' van deze regeling (totaal van administratieve lasten voor bedrijven en uitvoeringskosten overheid) (EZ, 2016).

\subsection{Aanpak}

De aanpak van de evaluatie bestaat onder meer uit het verzamelen van data via een enquête onder akkerbouwers, fruittelers en veehouders die snijmais telen, uit interviews met belanghebbenden aan 
zowel de aanbod- als vraagzijde, en een scenarioanalyse. In meer detail gaat het om de volgende zes stappen (Figuur 1.2):

A. Bestuderen van de informatie van RVO.nl, aangevuld met bevindingen van stakeholders, om een beeld te krijgen van de uitvoeringskosten van de regeling, de kwaliteit van de uitvoering en de klanttevredenheid van derden

B. Stakeholderanalyse op basis van zeven diepte-interviews om (gevoelige) informatie te verzamelen over vraag (LTO, NAV en NFO) en aanbod (Achmea, AgriVer, OFH en Vereinigte Hagel)

C. Analyse ontwikkelingen aanbodzijde op basis van websites en interviews met verzekeraars

D. Analyse preferentie en perceptie telers op basis van enquête

E. Analyse structuurkenmerken gebruikers versus niet-gebruikers

F. Scenarioanalyse extreme weersevenementen.

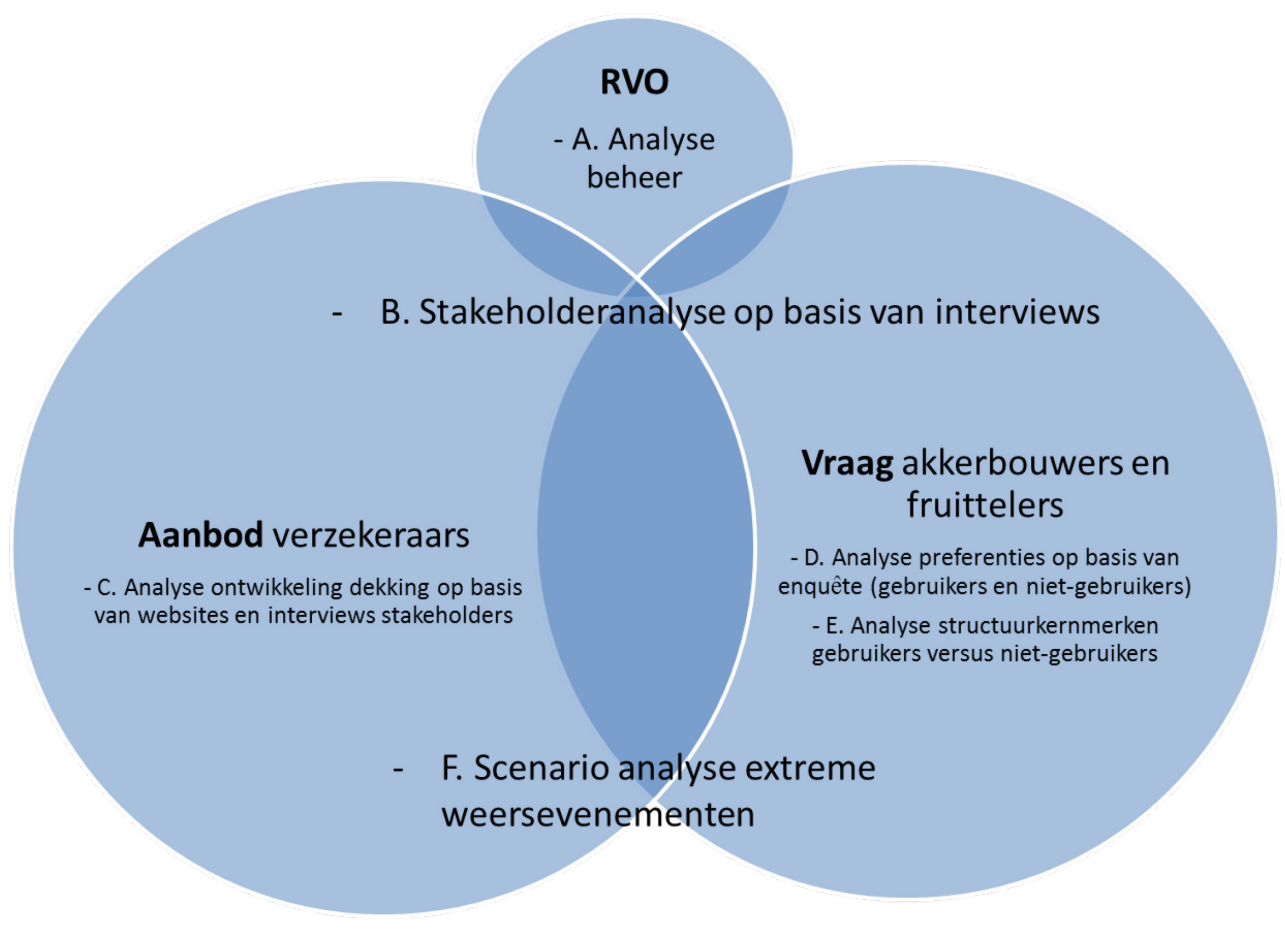

Figuur 1.2 Activiteiten voor de evaluatie

De gecombineerde resultaten van de hiervoor beschreven deelactiviteiten geven inzicht in het bereik, de doeltreffendheid en de doelmatigheid van de Regeling.

\subsection{Opbouw van het rapport}

In aansluiting op de inleiding in dit hoofdstuk, behandelt hoofdstuk 2 de beleidstheorie en opzet van de Regeling.

Hoofstuk 3 beschrijft het bereik van de van de Regeling, de structuurkenmerken van de deelnemers, de dynamiek hierin en de verschillen in structuurkenmerken met niet-deelnemers aan de BWV. Een en ander is gebaseerd op data van RVO.nl.

Hoofdstuk 4 analyseert de factoren achter de doeltreffendheid van de Regeling, zowel op basis van de enquête als op basis van de interviews met belanghebbenden.

Hoofdstuk 5 analyseert de doelmatigheid van de Regeling, waarbij een vergelijking wordt getroffen met brede weersverzekeringen van andere landen. 
Hoofdstuk 6 is gewijd aan de verzoeken tot schadevergoeding aan de overheid bij extreme weersituaties.

Hoofdstuk 7 ten slotte geeft de synthese van de evaluatie en een discussie over de resultaten inclusief aanbevelingen. 


\section{$2 \quad$ Beleidstheorie}

\section{$2.1 \quad$ Inleiding}

Dit hoofdstuk behandelt de beleidstheorie en opzet van de Regeling brede weersverzekering. Een en ander wordt geplaatst tegen de achtergrond van de algemene theorie rondom verzekeringen, waarbij aspecten als risicohouding en risicoperceptie, informatieasymmetrie en antiselectie aan de orde komen. Na een korte schets van de zogenaamde holistische risicobenadering van de OESO, wordt ingegaan op marktfalen, neveneffecten en de gevolgen ervan voor het overheidsoptreden.

\subsection{Risico's en risicobeheer}

\section{Holistische benadering}

Ondernemen gaat gepaard met het nemen van risico's. Risico's en risicobeheerinstrumenten dienen in hun samenhang beoordeeld te worden. De risico's moeten op een geaccepteerd niveau worden gebracht en gehouden, rekening houdend met de doelstellingen van de ondernemer. Dat betekent niet dat risicobeheer altijd tot de minst risicovolle activiteiten leidt. Het is een afweging tussen risico en het verwachte rendement. Een groot deel van de risico's kan door de ondernemers zelf met gerichte maatregelen worden ingeperkt of met behulp van een marktpartij, zoals verzekeraars, voldoende afgedekt worden. Of en in welke mate een ondernemer gebruik maakt van gerichte maatregelen of van de voorzieningen van de markt, is een beslissing van de ondernemer. Verzekeringen kunnen als strategie voor risicospreiding een alternatief zijn voor diversificatie, bijvoorbeeld het telen van meerdere gewassen op meerdere locaties. Verzekerde ondernemers kunnen zich dus in theorie meer specialiseren, wat efficiëntiewinst en schaalvoordelen oplevert.

De OESO onderscheidt bij de holistische benadering drie risicosegmenten, waarvoor theoretisch gezien verschillende risicobeheerinstrumenten het meest geëigend zijn (OESO, 2009):

1. Risico's die vaak voorkomen waarbij de verliezen beperkt zijn. Deze risico's worden effectief beheerd op het bedrijf zelf (aangeduid als 'risk retention layer', ofwel het eigen risico).

2. Risico's die zelden voorkomen en gepaard gaan met grote schade. Bij deze zogenaamde rampen is vaak sprake van marktfalen. De overheid wordt vaak een rol toegedicht bij het afwikkelen van de gevolgen van rampen (aangeduid als 'market failure layer').

3. Tussen deze twee segmenten bestaat een groep intermediaire risico's waarvoor verzekeringen of andere marktoplossingen goed kunnen functioneren. Soms ontbreken deze oplossingen of wordt er weinig gebruik van gemaakt door ondernemers (aangeduid als 'insurance layer').

Tijdens en na een ramp kunnen belanghebbenden van mening verschillen over het classificeren van een ramp. De discussie spitst zich dan toe op de grenzen tussen de 3 risicosegmenten. De classificatie heeft invloed op wie er voor de gevolgen van een ramp (financiële) verantwoordelijkheid moet nemen. De OESO concludeert dat er bij zogenaamde rampen voor de overheid een rol is. De overheid is namelijk verantwoordelijk voor het corrigeren van marktfalen als publieke belangen in het geding zijn. Ook voor de Nederlandse overheid geldt dat haar rol met betrekking tot risico's in de land- en tuinbouw zich beperkt tot interventies bij rampen. Publiek-private partnerships en ex-ante arrangementen worden nagestreefd bij rampen die de capaciteit van het individuele bedrijf overstijgen (Van Asseldonk et al., 2014).

\section{Marktfalen}

Marktfalen geldt als centraal argument voor het rechtvaardigen van directe overheidsbetrokkenheid (Bator, 1958). Er is marktfalen wanneer de voortbrenging van, en handel in, goederen niet tot een marktevenwicht leidt waarbij de maatschappelijke welvaart maximaal is. De markt kan geen oplossing 
tot stand brengen omdat het een publiek goed betreft, of omdat er onder andere hoge

transactiekosten zijn, toetredingsbarrières en asymmetrische informatie (Krugman et al., 2006).

Met betrekking tot weersgerelateerde risico's zijn er meerdere oorzaken waarom marktpartijen niet tot een geschikt risicoafdekkingsysteem komen, zowel aan de vraagzijde als aanbodzijde:

- $\mathrm{Er}$ is informatieasymmetrie tussen de partijen die een risico 'poolen' (verzekerde versus verzekeraar). Het strategische gedrag, dat door asymmetrische informatie mogelijk wordt gemaakt, verstoort de marktwerking. Onevenwichtigheid in informatie kan namelijk leiden tot een aantal ongewenste situaties:

- Het verschijnsel van moraliteit ('moral hazard') waarbij personen hun gedrag veranderen nadat ze een verzekering hebben afgesloten. Bijvoorbeeld verzekerde personen nemen dan meer risico's (zoals verbouwen van teelten op te natte gronden, of juist op te droge gronden), of spannen zich niet of minder in om schade te voorkomen omdat ze toch wel verzekerd zijn. Moraliteit heeft dus betrekking of verschil in informatie tussen twee partijen met een verschillend belang bij het nemen van een beslissing.

- Het verschijnsel van antiselectie waarbij slechts diegenen zich zullen verzekeren die ook daadwerkelijk (meer) risico lopen indien de mogelijkheid van premiedifferentiatie ontbreekt.

- Het risicobewustzijn is vaak te laag. Ondernemers (net als alle mensen) onderschatten vaak catastrofale risico's en zijn daardoor niet bereid de benodigde risicopremie te betalen. In samenhang hiermee heeft de overheid het imago dat deze de schades vergoedt als zich calamiteiten voordoen. Als gevolg van een geringe vraag is er een te smalle basis voor verzekeringsmaatschappijen om geschikte private verzekeringsproducten te ontwikkelen en te vermarkten.

De opvatting dat agrarische verzekeringsmarkten falen wordt vaak als argument aangevoerd voor het rechtvaardigen van een overheidsinterventie (in het geval van de BWV een premiesubsidie). De beslissing om tot interventie over te gaan is echter een politieke en geen wetenschappelijke uitkomst. Daarbij speelt ook de vraag hoe overheidsbeleid voor het marktfalen compensatie kan bieden, waarbij het middel niet erger mag zijn dan de kwaal.

\section{Neveneffecten}

Het is evident dat naarmate de premiesubsidie toeneemt ook de verzekeringsgraad toeneemt. Echter, negatieve neveneffecten worden vaker geobserveerd bij substantiële overheidsinterventies. In het geval van de BWV zijn potentiële negatieve neveneffecten met name:

- Verdringing ('crowding out') van bestaande private hagelverzekeringen. De stimuleringsmaatregel van de overheid, via een gerichte premiesubsidie BWV, kan ertoe leiden dat bestaande marktoplossingen benadeeld worden.

- Risicovoller gedrag telers ten koste van het algemene belang als gevolg van eerder genoemde moraliteit.

Beleidsmakers dienen rekening te houden met de potentiële negatieve neveneffecten. Een van de randvoorwaarden voor de implementatie van overheidsinterventies is dat risicobeheerinstrumenten moeten bijdragen aan het voorkomen of beperken van risico's en ook moeten bijdragen aan het verminderen van de schade indien een bepaalde crisissituatie zich voordoet.

\section{Overheidsinterventies}

Bij de opzet van een gesubsidieerde verzekering dient met de genoemde aspecten van marktfalen en negatieve neveneffecten rekening te worden gehouden. Op zich hoeven bovenstaande aspecten geen onoverkomelijk probleem te zijn, maar ze betekenen dat bij het ontwikkelen van een verzekering met name premiedifferentiatie, het eigen risico, risicopreventie en de acceptatievoorwaarden door de verzekeringsmaatschappij van belang zijn.

Een gedifferentieerde premie (op basis van risicofactoren als grondsoort, gevoeligheid gewas en genomen risicopreventiemaatregelen) is van belang ter voorkoming van antiselectie en ter vergroting van het draagvlak zodat het risico meer gespreid wordt. Moral hazard kan enerzijds worden beperkt door het invoeren van een substantieel eigen risico per verzekerde en anderzijds door het opstellen van acceptatievoorwaarden (via artikel over algemene uitsluitingen). Door het relatief hoog eigen 
risico wordt dus gekozen voor een verzekering met een continuïteitsgarantie van de verzekerde (in plaats van een volledige schadeloosstelling).

$\mathrm{Na}$ verloop van tijd nemen de transactiekosten per verzekerde af bij een toenemende verzekeringsgraad. Naarmate meer statistische claimgegevens over het optreden en de omvang van schade bekend worden, neemt de mogelijkheid van nauwkeuriger premiedifferentiatie toe. Een grotere spreiding van de risicoportefeuille gaat gepaard met minder heftige schommelingen van de jaarlijks verzekerde schadelast, echter door het openstellen van een verzekering neemt de absolute schadelast niet af (tenzij de verzekering een positief effect heeft op het nemen van risicopreventiemaatregelen). In het gunstigste geval zal na verloop van tijd het marktfalen ondervangen worden, zodat overheidsinterventie niet meer noodzakelijk is.

\subsection{Regeling brede weersverzekering}

De Regeling brede weersverzekering subsidieert de premie voor een BWV voor alle open teelten van de sectoren akkerbouw, vollegrondsgroententeelt, bollenteelt, sierteelt, fruitteelt en boomkwekerij. De subsidie wordt verstrekt aan een landbouwer, in de vorm van een financiële bijdrage voor de premie ten behoeve van een verzekering tegen de financiële gevolgen van ongunstige weersomstandigheden (Staatscourant, 2015). Onder ongunstige weersomstandigheden worden in elk geval begrepen:

a. weersomstandigheden die volgens een schade-expert of het Koninklijk Nederlands Meteorologisch Instituut met een natuurramp kunnen worden gelijkgesteld, en

b. elk van de volgende weersomstandigheden:
$1^{\circ}$. regenval $^{2}$
$2^{\circ}$. droogte ${ }^{3}$
$3^{\circ}$. (nacht)vorst
$4^{\circ}$. sneeuw
$5^{\circ}$. ijzel
$6^{\circ}$. storm
$7^{\circ}$. hagel, of
$8^{\circ}$. brand door blikseminslag.

De verzekering dekt - onder voorwaarden - het financieel verlies van de landbouwer voor zover dat:

1. meer is dan $30 \%$ van de gemiddelde jaarproductie in de laatste drie jaar of van de gemiddelde productie van drie van de laatste vijf jaar waarbij de hoogste en laagste productie van deze vijf jaar niet wordt meegerekend. ${ }^{4}$

2. het gevolg is van een lagere opbrengst in kwantiteit of kwaliteit;

3. optreedt op een aaneengesloten stuk grond waarop één enkel gewas wordt geteeld; en

4. redelijkerwijs is toe te rekenen aan ongunstige weersomstandigheden.

De subsidie bedraagt $65 \%$ van de verzekeringspremie, exclusief belastingen. Als het totaal van de aanvragen voor subsidies het beschikbare budget overschrijdt, wordt het subsidiepercentage evenredig verlaagd. Dit heeft zich in de periode 2010-2015 niet voorgedaan.

\section{Aannames bij opzetten Regeling}

Bij de start van de Regeling in 2010 werd er vanuit gegaan dat in een periode van 4 jaar alle openteeltondernemers een BWV zouden hebben (EZ, 2016). Na vier jaar zouden er dan genoeg

\footnotetext{
2 In de regeling zelf niet nader gedefinieerd. In de toelichting van de OFH (2016) op de BWV is extreme regenval gedefinieerd als $100 \mathrm{~mm}$ in 24 uur of $125 \mathrm{~mm}$ in 48 uur of $150 \mathrm{~mm}$ in 96 uur. Agriver geeft op de website als grenswaarden voor neerslagschade $50 \mathrm{~mm}$ in 24 uur, $84 \mathrm{~mm}$ in 48 uur en $100 \mathrm{~mm}$ in 96 uur. Vereinigte Hagel hanteert volgens de website als grenswaarden $50 \mathrm{~mm}$ in 24 uur, $85 \mathrm{~mm}$ in 48 uur, $110 \mathrm{~mm}$ in 96 uur en $240 \mathrm{~mm}$ in 28 dagen.

3 In de regeling zelf niet nader gedefinieerd. In de toelichting van de OFH (2016) gedefinieerd als $328 \mathrm{~mm}$ tussen 1 april en 30 september; Agriver geeft geen informatie hierover op de website, Vereinigte Hagel gaat uit van een negatieve waterbalans van $250 \mathrm{~mm}$ tussen 1 april en 30 september.

4 Het is onder voorwaarden mogelijk om bij financieel verlies van minder dan $30 \%$ tot uitkering te komen (artikel 15 ).
} 
deelnemers zijn om de premiesubsidie af te kunnen bouwen. Ook werd ervan uitgegaan dat iedere deelnemers zijn gehele areaal, met alle gewassen zou verzekeren; dit is uiteindelijk niet verplicht gesteld. Ten slotte was de aanname dat bij een calamiteit geen schadevergoeding meer werd betaald door de overheid.

Aan deze aannames lagen de volgende hypotheses ten grondslag:

- Het aantal deelnemers is afhankelijk van:

- bekendheid van de Regeling

- besef dat er geen schade wordt vergoed door de overheid

- mogelijkheid van alternatieve maatregelen om schade te voorkomen

- condities van de verzekering

- regels van de subsidie.

- Voldoende deelnemers leiden tot een economisch aantrekkelijke premie, waardoor een subsidie niet meer nodig is.

- Met name de risicovolle teelten worden verzekerd.

- Bij beschikbaarheid van een BWV, waar alle plantaardige sectoren terecht kunnen voor alle ongunstige weersomstandigheden, vraagt de sector niet meer om schadevergoeding als gevolg van ongunstige weersomstandigheden.

- De deelnemers stappen over van een smalle weersverzekering naar een brede weersverzekering.

- Verzekeringsmaatschappijen worden door de BWV in staat gesteld om meer kennis op te bouwen over plantaardige teelten en de gevolgen die extreme weersomstandigheden hierop hebben.

- Meerdere aanbieders van een BWV, leidt tot concurrentie en zodoende tot economisch aantrekkelijke premies.

- Meerdere aanbieders van een BWV leidt tot versnippering van deelnemersaantallen en zodoende tot een langzamere afname van het premieniveau (EZ, 2016).

Deze hypotheses van het ministerie van EZ - die de basis vormden van de onderzoeksvragen opgesteld door het ministerie van EZ - sluiten goed aan bij het theoretisch kader zoals uiteengezet in paragraaf 2.2. In hoeverre het marktfalen is verminderd sinds openstelling van de Regeling, terwijl negatieve neveneffecten worden vermeden, zijn hierbij de twee essentiële elementen. 


\section{$3 \quad$ Bereik van de Regeling}

\subsection{Inleiding}

Op basis van de data van RVO.nl schetst dit hoofdstuk het bereik van de Regeling in termen van aantal bedrijven met een BWV en verzekerd areaal. Ook worden op basis van data van RVO.nl enkele structuurkenmerken van de bedrijven gegeven en vergeleken met gegevens van bedrijven die geen BWV hebben afgesloten.

Hoewel Wageningen Economic Research beschikt over de integrale landbouwtelling, ontbreekt in de Landbouwtelling informatie over het al dan niet afsluiten van een brede weersverzekering door landen tuinbouwbedrijven. Over die informatie beschikt RVO.nI wel. RVO.nl wilde deze informatie wel beschikbaar stellen, maar uit het oogpunt van privacy zonder de BRS-nummers ${ }^{5}$ van de bedrijven. Hierdoor was het niet mogelijk een koppeling te maken tussen de Landbouwtelling en de gegevens van RVO.nl. De dataset die is aangevraagd bij RVO.nl is minder uitgebreid dan de dataset die beschikbaar is via de Landbouwtelling. ${ }^{6}$

\subsection{Aantal bedrijven met een brede weersverzekering}

Op basis van koppeling tussen bestanden van RVO.nl is bepaald hoeveel bedrijven een BWV hebben afgesloten per jaar en in welke sector deze bedrijven hoofdzakelijk werkzaam zijn. ${ }^{7}$

Sinds 2010 is het aantal verzekerden meer dan verdubbeld tot 1.189 in 2015 (definitieve aantal deelnemers). Voor 2016 is medio juli bekend dat 1.719 ondernemers een voorlopige aanvraag voor premiesubsidie hebben gedaan. Het daadwerkelijke aantal afgesloten verzekeringen ligt in de regel enkele honderden lager, maar uit deze cijfers blijkt wel een verdere stijging van het aantal deelnemers (mondelinge info RVO.nl).

Bedrijven met hoofdzakelijk akkerbouwgewassen of fruitteelt zijn de voornaamste gebruikers van de BWV. Van de bedrijven met fruitteelt is in 2015 22\% verzekerd. In de dataset waren op basis van gewasarealen van aardappelen, suikerbieten en uien bijna 6.500 bedrijven ingedeeld als akkerbouwbedrijf. Hiervan heeft $7 \%$ een BWV. ${ }^{8}$ In de laatste twee jaren zit de groei van het aantal deelnemers vooral bij de bedrijven met akkerbouwgewassen en is het aantal deelnemers met fruit tamelijk stabiel. Figuur 3.1 toont het aantal bedrijven met een BWV naar hoofdactiviteit.

\footnotetext{
5 Het BRS-nummer is het registratienummer van een bedrijf zoals dat door RVO.nl wordt gebruikt en ook in de Landbouwtelling staat.

6 Met financiële ondersteuning van het ministerie van EZ zijn recent de Landbouwtellingen voor een beperkt aantal jaren gekoppeld met data van de Belastingdienst. Daardoor is het mogelijk om structuurgegevens te koppelen met fiscaaleconomische gegevens van de winst- en verliesrekening zoals opbrengsten en kosten, maar ook balansgegevens zoals eigen vermogen, schulden en liquide middelen. Een tijdreeksanalyse van deze data van verzekerde telers versus nietverzekerde telers zou een aanvulling zijn geweest. Echter, de CBS Landbouwtelling inclusief verrijkte data met koppeling fiscale boekhouding loopt twee jaar achter en is voor het huidige onderzoek minder geschikt (met name verzekerden in de laatste jaren zonder verrijkte data). Voor eventueel toekomstige evaluaties is dit wel een optie.

7 Het gaat om een database met voorlopige cijfers over deelname 2015, omdat in april 2016 - toen de analyse plaatsvond de definitieve cijfers voor 2015 nog niet bekend waren. Alle analyses in dit hoofdstuk zijn op deze voorlopige database gebaseerd, tenzij anders aangegeven. Zie ook Bijlage 2 voor een uitleg over het gebruik van de data.

8 Gegeven de trendmatige jaarlijkse daling van het aantal land- en tuinbouwbedrijven in Nederland, groeit het relatieve aandeel verzekerde bedrijven.
} 


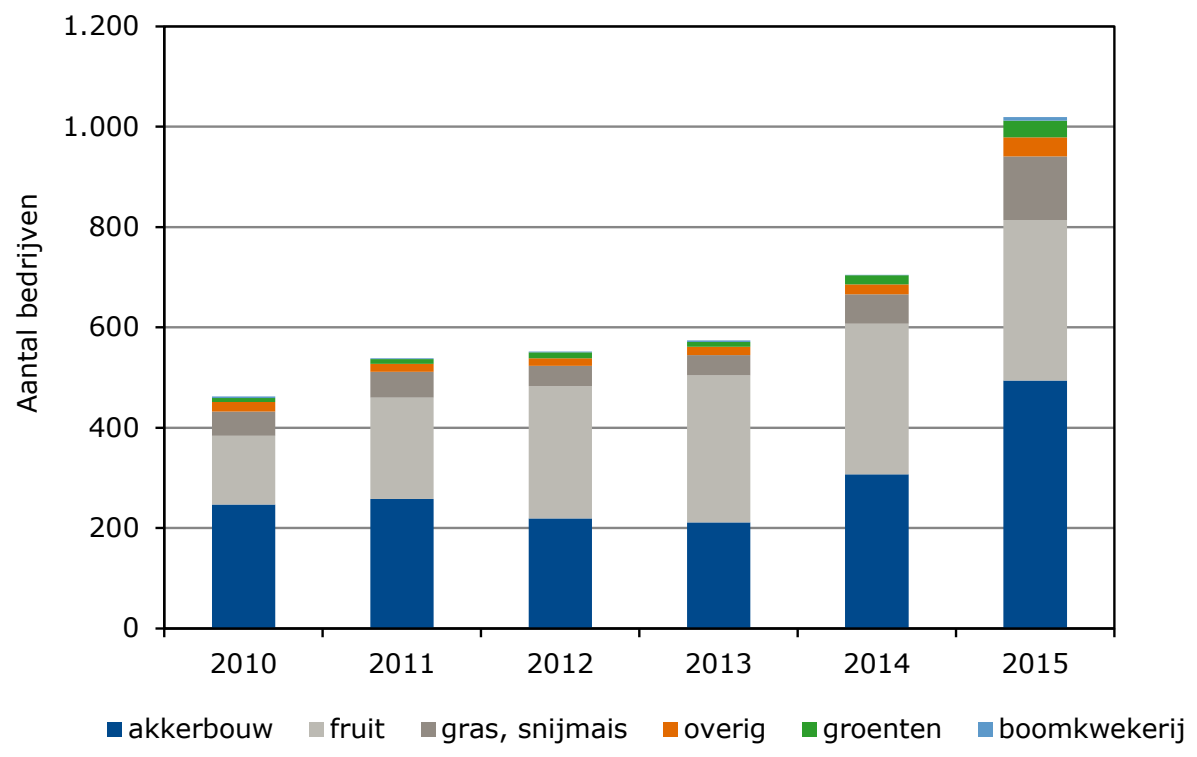

Figuur 3.1 Aantal bedrijven naar hoofdactiviteit met een BWV, 2010-2015 Bron: RVO.nl, bewerking Wageningen Economic Research.

\subsection{Verzekerd areaal en uitgekeerde premiesubsidie}

Het verzekerde areaal is niet bekend op basis van de data van RVO.nl. Wel is bekend of een bedrijf verzekerd is en wat het areaal van dat bedrijf is.

Tot 2012 nam het aandeel van het areaal appels en peren op bedrijven met een BWV jaarlijks flink toe, daarna vlakte de stijging af (Figuur 3.2). In 2015 werd ruim 35\% van het areaal appels en bijna $30 \%$ van het areaal peer geteeld op bedrijven met een verzekering. Bij klein fruit wordt meer gebruik gemaakt van regenkappen, tunnels en dergelijke dan bij appel en peer. Voor die bedrijven is een BWV minder interessant.

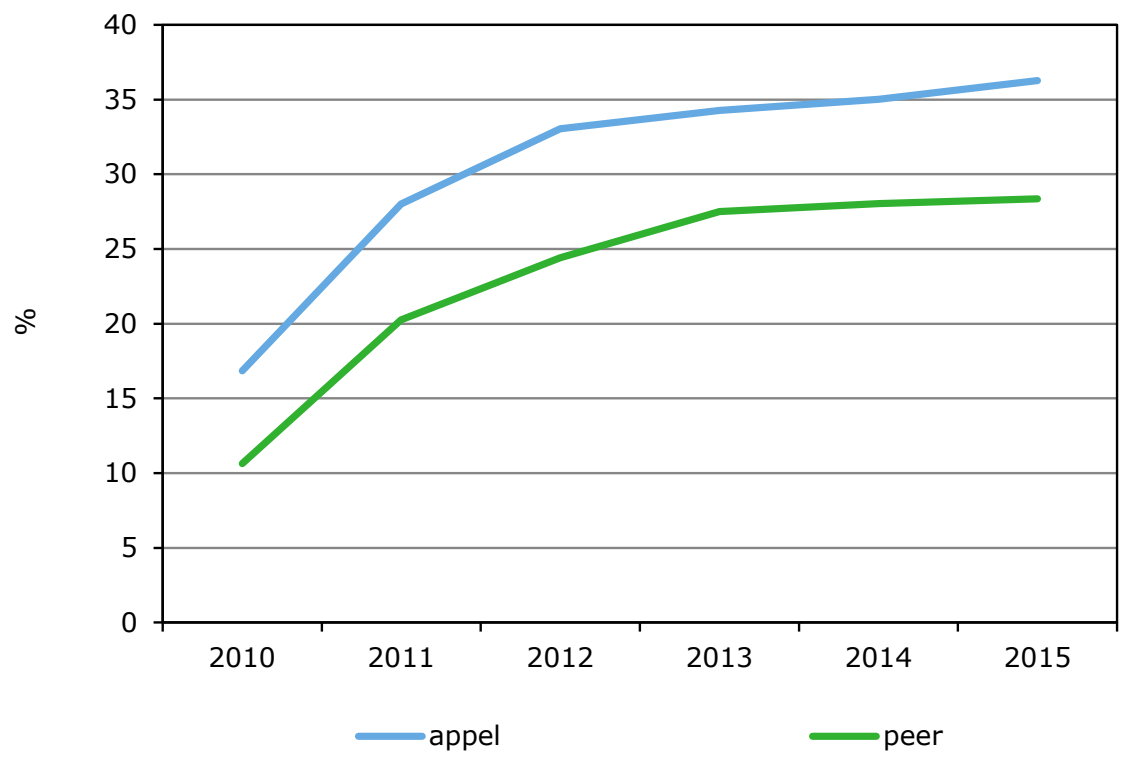

Figuur 3.2 Aandeel areaal appel en peer (\%) op bedrijven met een BWV ten opzichte van totaal areaal, 2010-2015

Bron: RVO.nl, bewerking Wageningen Economic Research. 
Bij de akkerbouwgewassen nam het areaal op bedrijven met een verzekering sinds 2013 toe (Figuur 3.3). In 2015 wordt bijna 14\% van de zaaiuien geteeld op bedrijven met een BWV. Voor de andere akkerbouwgewassen ligt dit rond de $8 \%$.

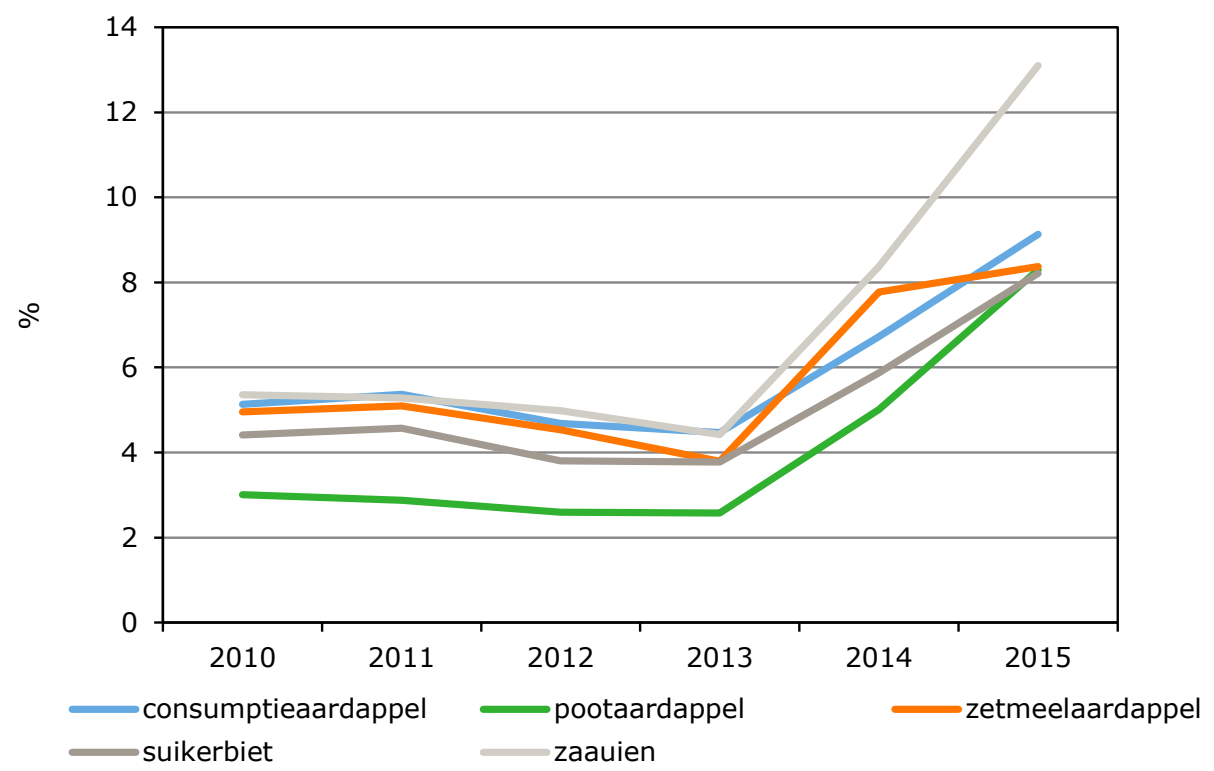

Figuur 3.3 Aandeel areaal akkerbouwgewassen (\%) op bedrijven met een BWV ten opzichte van totaal areaal, 2010-2015

Bron: RVO.nl, bewerking Wageningen Economic Research.

Ruim de helft van de verzekerden heeft een bedrijf in de provincies Flevoland, Groningen, NoordBrabant, Zeeland of Gelderland. ${ }^{9}{ }^{10}$ Deze spreiding vloeit voort uit het feit dat Flevoland, Groningen en Zeeland provincies zijn met een groot areaal akkerbouw. Fruitteelt vindt voornamelijk plaats in Gelderland en Zeeland.

In 2015 is er bijna $8 \mathrm{mln}$. euro uitgekeerd als tegemoetkoming in de premie voor de BWV. Aan bedrijven in de provincies Gelderland en Limburg is meer dan $1 \mathrm{mln}$. uitgekeerd. Limburg is de provincie waar het meest klein fruit wordt geteeld van Nederland. De premie voor klein fruit is hoger dan voor appels en peren, waardoor de tegemoetkoming ook hoger is.

\footnotetext{
9 Zie ook Bijlage 2, Figuur B2.1.

${ }^{10}$ De RVO.nl-data geven op provincieniveau inzicht in de vraag of een bedrijf een BWV heeft afgesloten, maar niet voor welke gewassen of in welke gebieden die gewassen worden verbouwd. Een nadere uitsplitsing of een bedrijf in een gebied ligt met een vergroot risico op extreme neerslag of droogte is daarom niet te maken.
} 
Tabel 3.1 Uitbetaalde bedragen tegemoetkoming premie BWV naar provincie, 2010-2015

\begin{tabular}{lrrrrrr} 
& 2010 & 2011 & 2012 & 2013 & 2014 \\
Drenthe & 63.200 & 81.700 & 97.200 & 97.200 & 139.000 & 242.500 \\
\hline Flevoland & 294.200 & 301.900 & 299.200 & 453.600 & 646.900 & 945.200 \\
\hline Friesland & 33.100 & 50.100 & 43.300 & 20.000 & 22.200 & 32.700 \\
\hline Gelderland & 817.900 & 905.500 & 1.264 .600 & 1.294 .200 & 1.271 .400 & 1.758 .800 \\
\hline Groningen & 95.000 & 99.800 & 74.900 & 78.300 & 137.600 & 282.000 \\
\hline Limburg & 456.700 & 624.800 & 896.200 & 894.000 & 865.500 & 1.307 .400 \\
\hline Noord-Brabant & 496.700 & 718.300 & 776.400 & 872.100 & 779.000 & 1.098 .400 \\
\hline Noord-Holland & 17.300 & 42.200 & 40.800 & 85.600 & 59.500 & 112.700 \\
\hline Overijssel & 11.700 & 11.300 & 5.200 & 11.300 & 13.100 \\
\hline Utrecht & 181.500 & 235.900 & 272.200 & 239.400 & 228.700 \\
\hline Zeeland & 359.800 & 523.900 & 609.500 & 677.500 & 705.600 & 87.300 \\
\hline Zuid-Holland & 161.800 & 257.500 & 318.300 & 396.600 & 461.800 \\
\hline Onbekend & 5.000 & 5.000 & 4.400 & 5.200 & 7.000 \\
\hline Totaal & 2.993 .800 & 3.858 .000 & 4.702 .300 & 5.125 .000 & 5.337 .300 & 7.764 .400 \\
\hline
\end{tabular}

a) op basis van definitieve cijfers.

Bron: RVO.nl, bewerking Wageningen Economic Research

Het jaarlijkse uitbetaalde bedrag aan premiesubsidie is gestegen van 3,1 mln. euro in 2010 tot $7,8 \mathrm{mln}$. euro in 2015, dat is minder dan het beschikbare premieplafond van $9 \mathrm{mln}$. euro in 2015 (Tabel 3.2).

Tabel 3.2 Jaarlijkse uitbetaalde bedrag aan premiesubsidie, 2010-2015

\begin{tabular}{lllllll} 
& 2010 & 2011 & 2012 & 2013 & 2014 & 2015 \\
Begrote subsidie a) & 9,36 & 10,62 & 12,48 & 12,48 & 13,33 & 9,00 \\
\hline Uitbetaalde premiesubsidie b) & 3,1 & 4,3 & 4,8 & 5,3 & 5,6 & 7,8 b)
\end{tabular}

(in mln. euro)

a) Voor de periode 2010-2013 gebaseerd op de melding van de Regeling aan Brussel; voor 2014 op basis van de Regeling GLB-inkomenssteun 2006 via wetten.nl. Voor 2015 via RVO.nl;

b) Via RVO.nl. Het verschil met de bedragen in Tabel 3.1 wordt voor de jaren 2010-2015 grotendeels verklaard door de selectie van de bedrijven (zie Bijlage 2).

\subsection{Structuurkenmerken deelnemers BWV}

\section{Fruitteeltbedrijven}

De fruitteeltbedrijven met een BWV zijn groter dan de bedrijven zonder. De gemiddelde omvang van de bedrijven met een verzekering ligt rond de 20 ha; de bedrijven zonder verzekering zijn ruim 5 ha kleiner. Ongeveer $40 \%$ van de fruitbedrijven zonder verzekering is kleiner dan 5 ha. De bedrijven tussen de 10 en 15 ha hebben relatief het vaakst een verzekering (bijna $30 \%$ van de bedrijven met een verzekering). ${ }^{11}$

Op de fruitbedrijven zonder verzekering bestaat 70\% van het areaal uit appel of peer (Tabel 3.3). Bij de bedrijven met een verzekering ligt dit aandeel iets hoger (78\%). In de periode 2010-2015 zijn de veranderingen in de verhouding tussen de gewassen niet sterk veranderd.

\footnotetext{
${ }^{11}$ Zie ook Bijlage 2, Figuur B2.2.
} 
Tabel 3.3 Verdeling gewassen (\%) op bedrijven met en zonder BWV, 2010-2015

\begin{tabular}{lllllllll} 
& & 2010 & 2011 & 2012 & 2013 & 2014 & 32 & 32 \\
Niet verzekerd & Appel & 37 & 32 & 31 & 34 & 36 & 38 & 40 \\
\hline & Peer & 44 & 34 & 35 & 32 & 30 & 30 \\
\hline \multirow{2}{*}{ Verzekerd } & Overig & 19 & 34 & 47 & 44 & 44 & 31 \\
\hline & Appel & 49 & 39 & 35 & 17 & 19 & 20 & 37 \\
\hline
\end{tabular}

Uit een analyse over de periode 2007-2015 van de bedrijfsomvang blijkt dat van de fruitbedrijven met een BWV iets meer dan de helft van de bedrijven in omvang groeide. Bij de bedrijven zonder verzekering is dit minder dan de helft. ${ }^{12}$

\section{Akkerbouwbedrijven}

Evenals fruitbedrijven zijn de akkerbouwbedrijven met een verzekering groter dan de bedrijven zonder verzekering (84 respectievelijk 60 ha in 2015). Van de bedrijven die verzekerd zijn, is bijna een derde groter dan 100 ha. Bij de bedrijven zonder verzekering is dit $15 \% .^{13}$

Tabel 3.4 toont dat de hoofdgewassen ongeveer de helft van het totale areaal beslaan. Tussen de akkerbouwbedrijven die wel en niet verzekerd zijn, is het verschil in de verdeling klein. Ook over de jaren heen is de verdeling tussen de gewassen stabiel.

Van de bedrijven die minimaal drie jaar een verzekering hadden, is bijna $60 \%$ gegroeid in omvang. Bij de bedrijven zonder verzekering was dat minder dan de helft. ${ }^{14}$

Tabel 3.4 Aandeel hoofdgewas op akkerbouwbedrijven in total areaal naar wel/niet verzekerd, 2010-2015

\begin{tabular}{|c|c|c|c|c|c|c|c|}
\hline & & 2010 & 2011 & 2012 & 2013 & 2014 & 2015 \\
\hline \multirow[t]{4}{*}{ Niet verzekerd } & Consumptieaardappelen & 13 & 13 & 12 & 13 & 13 & 12 \\
\hline & Pootaardappelen & 8 & 8 & 9 & 8 & 8 & 10 \\
\hline & Suikerbieten & 13 & 13 & 14 & 14 & 14 & 11 \\
\hline & Zaaiuien & 4 & 5 & 4 & 4 & 4 & 5 \\
\hline \multirow[t]{4}{*}{ Wel verzekerd } & Consumptieaardappelen & 16 & 16 & 15 & 16 & 15 & 14 \\
\hline & Pootaardappelen & 5 & 5 & 5 & 5 & 7 & 8 \\
\hline & Zetmeelaardappelen & 9 & 10 & 10 & 9 & 11 & 8 \\
\hline & Suikerbieten & 13 & 14 & 13 & 14 & 14 & 10 \\
\hline
\end{tabular}

\section{Grondsoort}

Van de gewassen consumptieaardappelen en pootaardappelen is bekend of deze op klei/löss dan wel zand/veen worden geteeld. In 2014 werd $7 \%$ van het areaal poot- en consumptieaardappelen geteeld op klei/löss op bedrijven met een BWV. ${ }^{15}$ Voor aardappelen op zand/veen was dat 4\% (Tabel 3.5).

\footnotetext{
12 Zie ook Bijlage 2, Figuur B2.3.

${ }^{13}$ Zie ook Bijlage 2, Figuur B2.4.

${ }_{15}^{14}$ Zie ook Bijlage 2, Figuur B2.5.

${ }^{15}$ Het is hierbij niet gegeven is dat de percelen met aardappels ook waren verzekerd, maar dit is wel aannemelijk.
} 
Tabel 3.5 Aandeel poot- en consumptieaardappelen geteeld op bedrijven met een BWV, 20102014

\begin{tabular}{lrrrrr} 
& 2010 & 2011 & 2012 & 2013 & 2014 \\
Klei/löss & 5 & 5 & 5 & 5 & 7 \\
\hline Zand/veen & 1 & 1 & 1 & 1 & 4 \\
\hline
\end{tabular}

\section{Leeftijd en opleiding}

Uit de RVO.nl-data blijkt dat het gemiddelde geboortejaar van de oudste ondernemer niet veel verschilt tussen bedrijven met en zonder BWV (respectievelijk 1963 en 1960).

Van de ondernemers zonder een BWV heeft 54\% een mbo-opleiding, 12\% heeft een hbo- of universitaire opleiding. Bij de ondernemers met een verzekering heeft $68 \%$ een mbo-opleiding, $20 \%$ heeft een hbo-opleiding of hoger (Figuur 3.4).

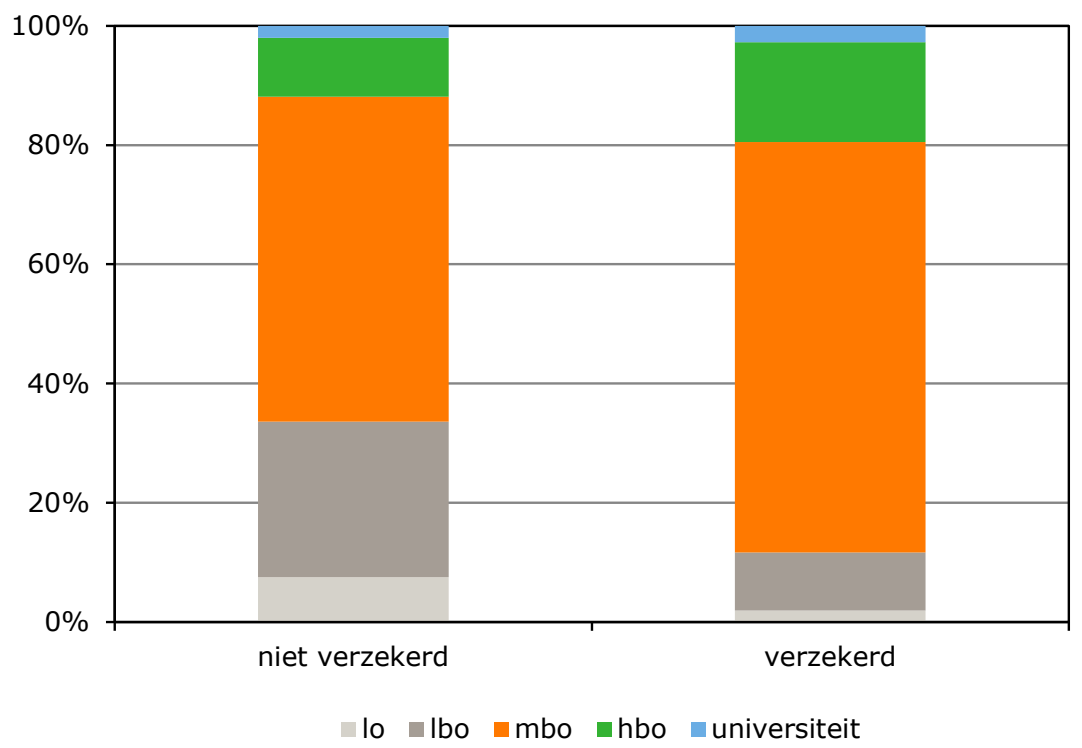

Figuur 3.4 Opleidingsniveau van ondernemers (\%) met en zonder BWV, 2013 Bron: RVO.nl, bewerking Wageningen Economic Research.

\subsection{Conclusies op basis van de analyse van de RVO.nl- data}

Het aantal bedrijven met een BWV is meer dan verdubbeld in de periode 2010-2015. Doordat meer bedrijven verzekerd zijn, is het totale areaal op bedrijven met een verzekering ook toegenomen. Het verzekerde areaal werd tot 2015 niet geregistreerd in de RVO.nl-gegevens.

Ruim de helft van de verzekerden heeft een bedrijf in de provincie Flevoland, Groningen, NoordBrabant, Zeeland of Gelderland. De bedrijven met een BWV zijn gemiddeld gesproken groter dan de bedrijven zonder een BWV; het aandeel bedrijven dat is gegroeid in omvang in de periode 2007-2015 is groter voor bedrijven met een BWV.

Het aandeel appel en peer in het areaal is groter op fruitbedrijven met een BWV; tussen de akkerbouwbedrijven die wel of niet verzekerd zijn is er nauwelijks verschil in de aandelen van de verschillende gewassen. 
De aannames dat in een periode van 4 jaar alle openteeltondernemers een BWV zouden hebben en iedere deelnemer zijn gehele areaal met alle gewassen zou verzekeren, worden door de data van RVO.nl niet gestaafd.

De theoretische veronderstelling dat verzekerde ondernemers zich meer kunnen specialiseren wordt ondersteund door de gegevens over fruitbedrijven, waar het aandeel appel en peer wat groter is op verzekerde bedrijven dan op niet-verzekerde bedrijven. De gegevens over de bedrijven met akkerbouwgewassen ondersteunen de hypothese niet. 


\section{$4 \quad$ Doeltreffendheid}

\section{$4.1 \quad$ Inleiding}

Dit hoofdstuk schetst op basis van de enquête onder agrarische ondernemers de factoren die van invloed zijn op het al dan niet afsluiten van een BWV door ondernemers. Ook gaat het hoofdstuk in op de bevindingen uit de interviews die zijn gehouden met vertegenwoordigers van verzekeraars en landbouworganisaties. Op basis van deze informatie ontstaat een beeld van de doeltreffendheid van de regeling. Onder doeltreffendheid wordt verstaan de mate waarin de Regeling het doel bereikt. De doelen zijn volgens het ministerie van EZ (2016) ten eerste aanbod van commercieel aantrekkelijke verzekeringen voor de verzekeraar en voor de agrarische ondernemingen, ten tweede geen/minder verzoeken (in aantallen en budget) tot schadevergoeding aan het ministerie van EZ.

\subsection{Bevindingen op basis van de enquête}

Het doel van de premiesubsidie was en is om een aantrekkelijke en marktconforme verzekeringsmogelijkheid te realiseren, waarmee bedrijven weerbaarder worden tegen ongunstige weersomstandigheden en financieel robuuster (EZ, 2016). Ondanks de substantiële premiesubsidie is het aantal ondernemers met een BWV beperkt. Van de weersverzekeringen is enkel de hagelverzekering al meer dan 100 jaar zonder overheidssteun succesvol (Asseldonk et al., 2009).

Uit de enquête ${ }^{16}$ onder agrarische ondernemers blijkt dat bijna $80 \%$ van de ondernemers met een BWV, een hagelverzekering had voordat ze een BWV afsloten. Deze cijfers ondersteunen het in paragraaf 2.2 beschreven 'crowding out'-effect, waarbij dankzij de overheidsinterventie een private verzekering wordt verdrongen. Het gaat zowel om fruittelers als bedrijven met akkerbouwgewassen (Figuur 4.1).

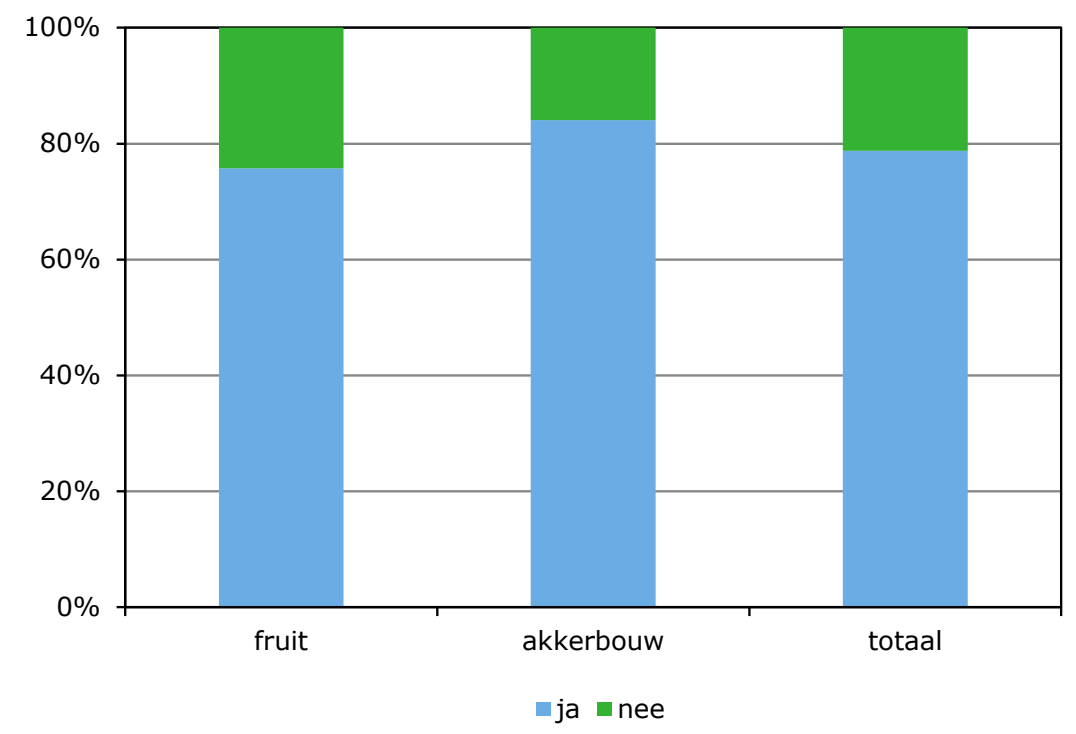

Figuur 4.1 Verdeling naar sector van deelnemers aan de BWV (\%) naar wel/niet afs/uiten hagelverzekering in het verleden Bron: enquête Wageningen Economic Research.

\footnotetext{
${ }^{16}$ Zie Bijlage 3 voor de opzet van de enquête.
} 
'worden gesteld dat bij een subsidiepercentage van 65\% een Brede Weerpolis ongeveer de helft kost van een traditionele Hagelschadepolis, terwijl sprake is van een bredere dekking. Bij een subsidiepercentage van slechts $40 \%$ is een Brede Weerpolis nog steeds goedkoper, namelijk zo'n 25\%. Pas bij een subsidiepercentage lager dan $22 \%$ is een Hagelschadepolis voordeliger' (OFH, 2016).

\section{Beweegredenen afs/uiten BWV}

De belangrijkste reden om een BWV af te sluiten is het feit dat dit de enige manier is om vanuit de overheid bij gewasschade nog een vergoeding te krijgen, zo blijkt uit de enquête, want de overheid springt niet meer op een andere wijze bij. Ook de mogelijkheid om specifieke gewassen te verzekeren en het feit dat de subsidie sinds 2015 direct in mindering wordt gebracht op de te betalen premie, zijn belangrijke overwegingen voor het afsluiten van de verzekering (Tabel 4.1).

Tabel 4.1 Redenen voor afs/uiten van BWV (\%)

\begin{tabular}{|c|c|c|c|c|c|c|}
\hline & $\begin{array}{l}\text { Heel } \\
\text { onbelangrijk }\end{array}$ & $\begin{array}{l}\text { Redelijk } \\
\text { onbelangrijk }\end{array}$ & Neutraal & $\begin{array}{l}\text { Redelijk } \\
\text { belangrijk }\end{array}$ & $\begin{array}{l}\text { Heel } \\
\text { belangrijk }\end{array}$ & Totaal \\
\hline Aantrekkelijke premie & 6 & 10 & 30 & 29 & 27 & 100 \\
\hline $\begin{array}{l}\text { Enige manier om vanuit } \\
\text { overheid tegemoetkoming } \\
\text { bij gewasschade te krijgen }\end{array}$ & 7 & 4 & 9 & 30 & 50 & 100 \\
\hline Kans op schade is groot & 4 & 6 & 19 & 40 & 31 & 100 \\
\hline $\begin{array}{l}\text { Mogelijkheid om specifieke } \\
\text { gewassen te verzekeren }\end{array}$ & 5 & 6 & 14 & 29 & 46 & 100 \\
\hline $\begin{array}{l}\text { Subsidie wordt direct in } \\
\text { mindering gebracht op } \\
\text { premie }\end{array}$ & 5 & 7 & 19 & 26 & 42 & 100 \\
\hline Zelf grote gewasschade gehad & 11 & 7 & 19 & 26 & 37 & 100 \\
\hline
\end{tabular}

Bron: enquête Wageningen Economic Research.

Respondenten zonder BWV geven als voornaamste redenen aan dat ze de dekking van de verzekering te beperkt vinden en het eigen risico en de premie te hoog. Ook het feit dat ze veronderstellen dat de continuïteit van het bedrijf niet in gevaar komt, de kans op gewasschade op het bedrijf klein achten en geen gewasschade hebben gehad de afgelopen jaren zijn belangrijke redenen om geen BWV af te sluiten (Tabel 4.2). 
Tabel 4.2

Redenen om geen BWV af te sluiten (\%)

\begin{tabular}{|c|c|c|c|c|c|c|}
\hline & $\begin{array}{l}\text { Heel } \\
\text { onbelangrijk }\end{array}$ & $\begin{array}{l}\text { Redelijk } \\
\text { onbelangrijk }\end{array}$ & Neutraal & $\begin{array}{l}\text { Redelijk } \\
\text { belangrijk }\end{array}$ & $\begin{array}{l}\text { Heel } \\
\text { belangrijk }\end{array}$ & Totaal \\
\hline $\begin{array}{l}\text { Continuïteit van bedrijf in geen } \\
\text { geval in gevaar }\end{array}$ & 9 & 10 & 36 & 34 & 11 & 100 \\
\hline $\begin{array}{l}\text { Hoogte van subsidie is vooraf niet } \\
\text { duidelijk }\end{array}$ & 16 & 10 & 41 & 17 & 17 & 100 \\
\hline Eigen risico te hoog & 8 & 6 & 16 & 30 & 40 & 100 \\
\hline $\begin{array}{l}\text { Geen grote gewasschade gehad } \\
\text { afgelopen jaren }\end{array}$ & 16 & 10 & 27 & 28 & 19 & 100 \\
\hline $\begin{array}{l}\text { Alternatieve maatregelen } \\
\quad \text { genomen }\end{array}$ & 28 & 17 & 20 & 17 & 18 & 100 \\
\hline Kans op schade door weer is klein & 11 & 11 & 39 & 28 & 12 & 100 \\
\hline $\begin{array}{l}\text { Bedrijf voldoet niet aan de } \\
\text { voorwaarden }\end{array}$ & 45 & 14 & 33 & 7 & 2 & 100 \\
\hline $\begin{array}{c}\text { Bij grote calamiteiten verleent } \\
\text { overheid wel noodsteun }\end{array}$ & 42 & 14 & 25 & 4 & 15 & 100 \\
\hline Premie is te hoog & 7 & 5 & 20 & 26 & 43 & 100 \\
\hline
\end{tabular}

Bron: enquête Wageningen Economic Research.

\section{Weerrisico}

Van de respondenten met een verzekering gaf $66 \%$ aan dat ze schade door hagel als zeer risicovol of erg risicovol beschouwen (Tabel 4.3). Vrijwel alle fruittelers met een verzekering vonden dat ook. In de akkerbouw wordt regen als het belangrijkste weerrisico gezien. In de meeste gevallen schatten de ondernemers zonder verzekering het risico lager in dan de ondernemers met een verzekering.

Tabel 4.3 Percentage respondenten dat weerrisico zeer risicovol of erg risicovol vindt

\begin{tabular}{|c|c|c|c|c|c|c|}
\hline & & Droogte & Hagel & Regen & Sneeuw & Vorst \\
\hline \multirow[t]{2}{*}{ Verzekerd } & Totaal & 10 & 66 & 46 & 4 & 32 \\
\hline & Akkerbouw & 14 & 46 & 70 & 2 & 11 \\
\hline \multirow[t]{2}{*}{ Niet verzekerd } & Totaal & 11 & 39 & 28 & 6 & 18 \\
\hline & Akkerbouw & 10 & 25 & 37 & 6 & 7 \\
\hline
\end{tabular}

Bron: enquête Wageningen Economic Research.

Op de vraag naar de risicohouding van de ondernemers zijn de verschillen in de waardering van de opties niet zo groot tussen ondernemers met en zonder een BWV. De enige uitzondering is bij de antwoorden op de vraag of men erop gokt geen grote schade te zullen lijden. Beduidend meer ondernemers zonder een BWV beantwoorden deze vraag positief dan ondernemers met een BWV (Tabel 4.4 en Tabel 4.5). 


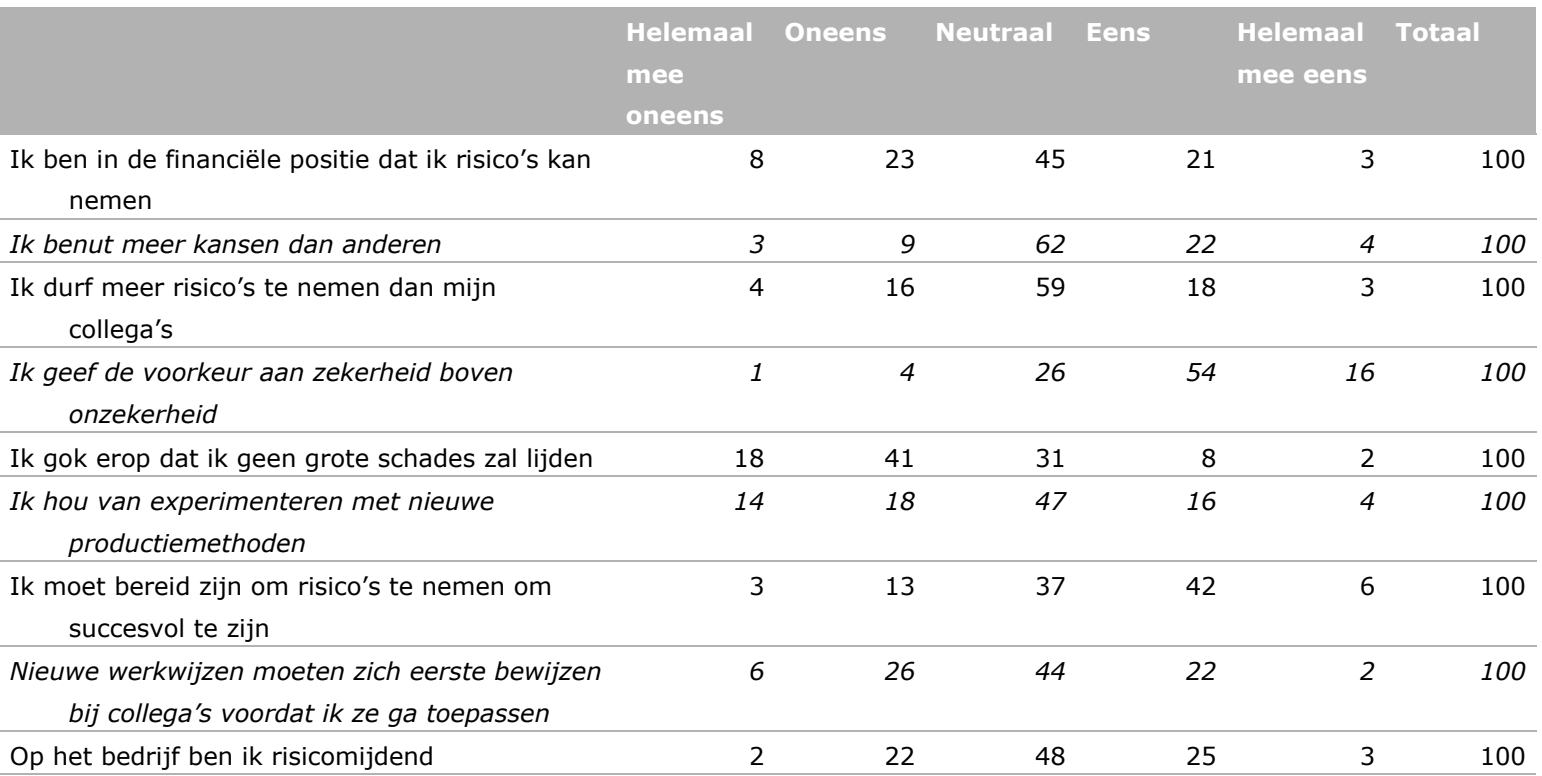

Bron: enquête Wageningen Economic Research.

Tabel 4.5 Risicohouding van ondernemers zonder BWV (\%)

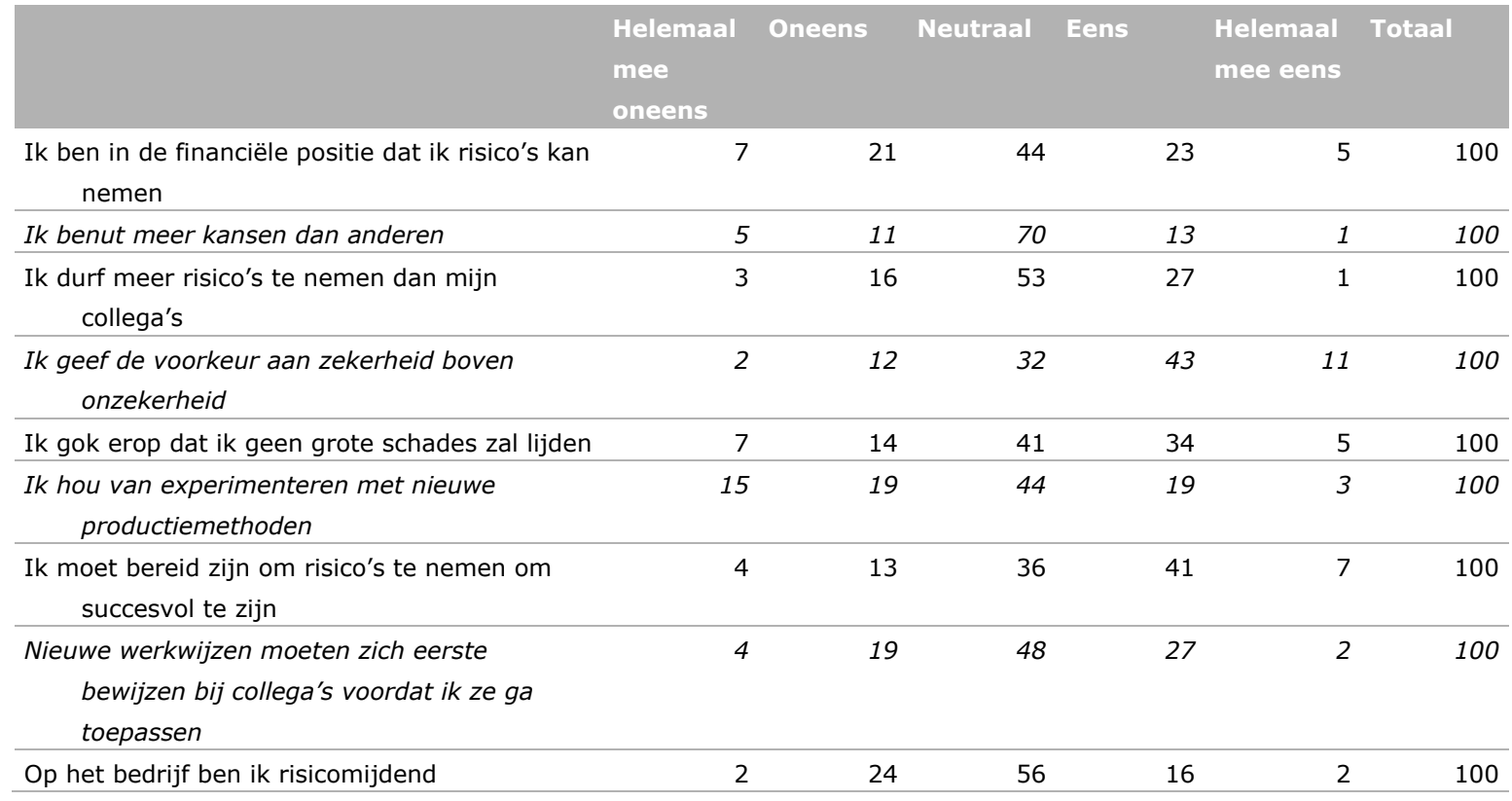

Bron: enquête Wageningen Economic Research.

\section{Rol overheid}

Op de vraag of de BWV na 2020 moeten blijven bestaan, inclusief de tegemoetkoming in de premie door de overheid zeggen vrijwel alle deelnemers aan de verzekering 'ja' in de enquête. De belangrijkste reden om de weersverzekering niet te continueren is het feit dat men vindt dat weerrisico's tot de normale bedrijfsvoering horen.

De meerderheid van de respondenten ziet in de toekomst een rol voor de overheid weggelegd door het subsidiëren van de premie. Vrijstellen van assurantiebelasting wordt in $26 \%$ van de gevallen gekozen. De hoge assurantiebelasting komt ook vaak terug bij de opmerkingen die worden geplaatst naar aanleiding in het vrije invoerveld aan het eind van de enquête. Er zijn 92 respondenten die een opmerkingen hebben geplaatst; hiervan refereren er 28 (30\%) aan de hoogte van de assurantiebelasting. 


\subsection{Bevindingen op basis van de interviews ${ }^{17}$}

\section{Fruittelers}

De belangstelling onder fruittelers is afhankelijk van de gevoeligheid van de regio voor weerschade. Hagelschade is daarbij voor fruittelers het belangrijkste risico, gevolgd door vorstschade. Hoe het bedrijfsblok is samengesteld is eveneens van belang: is er geografische spreiding van de percelen in een gebied of bestaat het bedrijfsareaal uit één aaneengesloten blok. Ook de financiële positie van het bedrijf wordt als factor van belang genoemd, zo wordt soms op verzoek van de bank een BWV afgesloten.

Fruittelers kunnen zelf preventieve maatregelen nemen om de schade te beperken door het plaatsen van hagelnetten. Hagelnetten vergen een forse investering ${ }^{18}$ en zijn daarom vooral interessant voor clubrassen als Kanzi. Bij eventuele hagelschade brengen deze duurdere soorten nog maar weinig op.

Een van de knelpunten die in de gesprekken naar voren kwam is de hoogte van de assurantiebelasting die over de brutopremie moet worden betaald. Deze bedraagt nu $21 \%$, tegen $9,7 \%$ tot 1 januari 2013.

Een mogelijk knelpunt is de hoogte van het beschikbare premieplafond van $9 \mathrm{mln}$. euro per jaar en de dreigende premiekorting bij een grote deelname aan BWV. Tot nu toe is het premieplafond niet overschreden, maar als de premiesubsidie sterk vermindert of wegvalt, zal het draagvlak voor de verzekering een stuk kleiner zijn. In de fruitteelt zijn de verzekerden vooral ondernemers die overstappen van de hagelverzekering. De verwachting is daarom dat het wegvallen van de premiesubsidie leidt tot een terugval naar de oude situatie, waarin fruittelers kiezen voor een hagelverzekering.

\section{Akkerbouwers}

Voor akkerbouwers bepalen de ligging van het bedrijf (al dan niet geografische spreiding van de percelen), het bouwplan en de vraag in hoeverre waterschappen al inspelen op grote neerslaghoeveelheden in korte tijd, of een BWV wordt afgesloten. Voor akkerbouw speelt voornamelijk het risico op overvloedige regenval. De belangrijkste gewassen om te verzekeren zijn aardappelen, wortels en bonen. De animo is het grootst in regio's waar schade ook daadwerkelijk is opgetreden (regio West-Brabant, midden Zeeland en zuiden van Zuid-Holland). Ervaring uit het verleden bij telers met weerschade speelt hierbij ook een rol. Sommigen maken jaarlijks de afweging om wel/niet te verzekeren.

In 2015 was er een redelijke groei onder akkerbouwers, mede omdat de premiesubsidie door RVO.NL werd overgemaakt naar verzekeraars. Hierdoor hoeven ondernemers minder voor te financieren, wat het gebruik heeft gestimuleerd. In de akkerbouw wordt onder de huidige voorwaarden van de verzekering nog een lichte groei verwacht. De snelle toename de laatste jaren is in belangrijke mate ook gekomen doordat verzekeraars sinds 2013 ook de mogelijkheid bieden om op gewasniveau een verzekering af te sluiten. In veel gevallen wordt dan enkel voor aardappelen een verzekering afgesloten. Voor 2013 gold de verzekering voor alle gewassen op het bedrijf.

Akkerbouwers nemen in toenemende mate zelf preventieve cultuurtechnische maatregelen om hun percelen weerbaarder te maken tegen de gevolgen van overmatige neerslag. Het gaat dan bijvoorbeeld om meer intensieve drainage en het frezen van sleuven om overtollig water weg te laten lopen. Bij overvloedige regenval zijn ook deze preventieve maatregelen niet meer toereikend.

Ook voor akkerbouwers zijn knelpunten de hoogte van de assurantiebelasting over de brutopremie en een mogelijk korting op de premiesubsidie bij het overschrijden van het maximale plafond van

\footnotetext{
${ }^{17}$ Zie Bijlage 4 voor een overzicht van de geïnterviewde personen.

${ }^{18}$ Volgens de NFO bedragen de kosten van een hagelnet circa 18.000 euro per ha en wordt anno 2016 zo'n $10 \%$ van het hardfruitareaal beschermd door middel van een hagelnet.
} 
$9 \mathrm{mln}$. euro. De hoogte van het eigen risico is eveneens een drempel, zeker in combinatie met de hoogte van de verzekeringspremie.

Zonder subsidie wordt volgens de geïnterviewde personen de premie te hoog voor akkerbouwers om zich te verzekeren en zullen de ondernemers de gevolgen van weerrisico's moeten accepteren. Akkerbouwers zijn vanuit het verleden wel bekend met sterke schommelingen in de resultaten (goede en slechte jaren). Een aantal ondernemers is in staat deze schommelingen te overbruggen. Dit zijn veelal ook de ondernemers die nu ook niet verzekerd zijn. Een aantal ondernemers kan vanwege de financiële positie dit risico niet dragen. Voor deze groep akkerbouwers is de BWV een belangrijk instrument, die soms ook op advies/verzoek vanuit de bank wordt afgesloten om het risico op weerschade te beperken. De BWV in de huidige vorm geeft ondernemers de keuze of ze zich wel/niet tegen weerrisico's willen verzekeren.

\section{Verzekeraars}

De BWV is zonder premiesubsidie enkel in de markt te zetten als alle telers van open teelten verplicht worden deel te nemen, zo komt naar voren uit de interviews. Zonder verplichte deelname of premiesubsidie zal het aantal verzekerden te klein zijn vanwege de hoge premie. Als de verzekering verplicht wordt voor alle open teelten in Nederland, speelt ook het probleem van de antiselectie niet: bij het ontbreken van een adequate premiedifferentiatie zullen alleen díe ondernemers een verzekering afsluiten die daadwerkelijk meer risico lopen.

De verwachting van de verzekeraars is dat bij afbouw van de premiesubsidie de transactiekosten, het risico en het premietarief gelijk blijven, maar de premie voor de ondernemer zal toenemen. Voor veel verzekerde telers is de subsidie een belangrijke drijfveer: indien deze verdwijnt is de verwachting dat maar weinig telers een verzekering zullen afsluiten.

De BWV is geen verzekering maar in feite een fonds dat alleen in extreme situaties tot een uitkering overgaat, vandaar dat er ook een hoog eigen risico is. Uiteindelijk is de kern van de verzekering het garanderen van de continuïteit van het bedrijf, aldus de verzekeraars.

\subsection{Conclusies op basis van de enquête en de interviews}

De cijfers over het hoge percentage ondernemers dat is overgestapt van een hagelverzekering naar een BWV ondersteunen het in paragraaf 2.2 beschreven 'crowding out'-effect, waarbij dankzij de overheidsinterventie een private verzekering wordt verdrongen. Het gaat zowel om fruittelers als bedrijven met akkerbouwgewassen.

De belangrijkste reden om een BWV af te sluiten is het feit dat dit de enige manier is om vanuit de overheid bij gewasschade nog een vergoeding te krijgen, zo blijkt uit de enquête. Dit ondersteunt de aanname bij de start van de Regeling dat het aantal deelnemers afhankelijk is van het besef dat er geen schade wordt vergoed door de overheid.

Wat betreft de voorwaarden van de verzekering, de mogelijkheid om specifieke gewassen te verzekeren en het feit dat de subsidie sinds 2015 direct in mindering wordt gebracht op de te betalen premie, blijken eveneens belangrijke overwegingen voor het afsluiten van de verzekering. De hoogte van de assurantiebelasting en de mogelijke korting op de premiesubsidie bij het overschrijden van het beschikbare premiebudget blijken belangrijke knelpunten.

Respondenten zonder BWV geven als voornaamste redenen aan dat ze de dekking van de verzekering te beperkt vinden en het eigen risico en de premie te hoog. De regelgeving rondom de premiesubsidie kan dus belemmerend uitwerken op deelname. 


\section{$5 \quad$ Doelmatigheid}

\section{$5.1 \quad$ Inleiding}

Dit hoofdstuk beschrijft de aanbieders van een BWV en gaat in op de werking van de Regeling en de uitvoering van de Regeling door RVO.nl en daarmee samenhangende kosten. Ook gaat het hoofdstuk in op de aanpak die andere EU-landen hanteren wat betreft risicomanagement. Zo wordt een beeld verkregen van de doelmatigheid van het beleid, waaronder de bereikte effecten in relatie tot de ingezette middelen wordt verstaan en van de doelmatigheid van de uitvoering, waaronder wordt verstaan of de Regeling op efficiënte wijze output realiseert (EZ, 2016).

\subsection{Aanbieders van een brede weersverzekering}

Bij de start van de Regeling in 2010 waren er vier aanbieders van een BWV: Onderlinge Weerschade Verzekering U.A. (OWV), Agriver, Onderlinge Fruittelers Hagelverzekeringsmaatschappij (OFH) en Vereinigte Hagel. Anno 2016 zijn er drie aanbieders van een BWV. In 2012 - na twee jaar - is OWV gestopt vanwege de geringe deelname.

\section{Agriver}

Agriver biedt een traditionele verzekering aan voor de gevolgen van hagelschade met een eigen risico van tenminste $3 \%$; de ondernemer kan echter voor een hoger eigen risico kiezen, en betaalt dan een lagere premie. Deze zogenaamde AgriVer Gewassen te velde-verzekering is uit te breiden met extra dekking voor storm, transport, nachtvorst en brand.

De Brede Weersverzekering dekt het financiële verlies dat kan ontstaan door schade aan gewassen als gevolg van natuurrampen en/of ongunstige weersomstandigheden. Omdat het een calamiteitenverzekering betreft, geldt bij deze verzekering een eigen risico of drempel van $30 \%$ van de schade.

Om in geval van regenval/droogte voor een schadevergoeding in aanmerking te komen dient te worden voldaan aan aanvullende voorwaarden. Ten eerste moet een bepaalde grenswaarde (in $\mathrm{mm}$ neerslag) zijn overschreden. Ten tweede moet de - door de EU bepaalde - schadedrempel van 30\% financieel verlies ${ }^{19}$ overschreden zijn.

Bij schade door (nacht)vorst, sneeuw, ijzel, storm, hagel, erosie en brand door blikseminslag geldt een vast eigen risico van $30 \%$ van de schade. Een schade-uitkering is beperkt tot maximaal de verzekerde som minus het eigen risico. Bij deze risico's is wel sprake van schadevergoeding op basis van werkelijk geleden schade.

\section{Onderlinge Fruittelers Hagelverzekeringsmaatschappij}

De Onderlinge Fruittelers Hagelverzekeringsmaatschappij (OFH) is gespecialiseerd in het verzekeren van appels, peren en ander fruit tegen hagelschade. De OFH biedt voor fruittelers een hagelschadepolis aan, die verzekert tegen schade aan de verwachte oogst als gevolg van hagel. Telers kunnen kiezen uit een eigen risico van $25 \%$ of $50 \%$; naarmate de schade groter is, neemt het eigen risico af.

\footnotetext{
${ }^{19}$ Volgens de Regeling, artikel 12 gaat het om 30\% van de gemiddelde jaarproductie in de laatste drie jaar of van de gemiddelde productie van drie van de laatste vijf jaar waarbij de hoogste en laagste productie van deze vijf jaar niet wordt meegerekend (Staatscourant, 2015).
} 
Daarnaast biedt OFH voor fruittelers in Nederland de Brede Weerpolis aan, die verzekert tegen schade als gevolg van hagel, storm, sneeuwdruk, vorst, ijzel, brand door blikseminslag, extreme droogte en extreme regenval. De OFH meldt op de website dat de dekking van de Brede Weerpolis vooral is gericht op het risico van hagelschade. De dekking voor de andere weerrisico's is beperkt.

De verzekeringsdekking van de Brede Weerpolis tegen hagelschade is gelijk aan de Hagelschadepolis. Er geldt een drempel van 30\% voor schade onder de BWV.

Telers kunnen kiezen uit een eigen risico van $30 \%$ of $50 \%$; naarmate de schade groter is, neemt het eigen risico af.

\section{Vereinigte Hagel}

Vereinigte Hagel biedt een dekking tegen hagelschade voor alle gewassen te velde, inclusief boomkwekerij, fruit, bloembollen en sierteeltgewassen. Daarnaast is het mogelijk een verzekering af te sluiten voor akkerbouwgewassen voor hagel aangevuld met stormschade, en schade door vorst en brand.

Vereinigte Hagel biedt ook de BWV aan, die verzekert tegen negen weerrisico's/weerscalamiteiten: hagel, storm, zware regen, erosie, vorst, sneeuw ijzel, droogte en brand door bliksem. Er geldt een drempel van $30 \%$ voor schade onder de BWV. De teler kan kiezen voor de normale, niet volledig subsidiabele dekking (met een premiesubsidie van minder dan 65\%) en voor een hoger eigen risico en goedkopere premie die volledig (de maximale 65\%) subsidiabel is.

\section{Premie en schade}

Het Verbond van Verzekeraars heeft tot circa 2002 cijfers van agrarische verzekeraars vastgelegd (zoals premievolume en schade-uitkeringen). Het Verbond van Verzekeraars is daarmee gestopt omdat er in deze branche zo weinig aanbieders zijn dat openbare cijfers herleid zouden kunnen worden tot individuele verzekeraars. Informatie over schade-uitkeringen, uitvoeringskosten en eventuele winsten worden niet bekend gemaakt aan RVO.nl.

De OFH is de enige verzekeraar die op de website inzicht geeft in de hoogte van de premies. Bij de andere twee verzekeraars kan deze informatie niet via de website achterhaald worden, maar dient een offerte aangevraagd te worden.

\subsection{Procedure}

De Regeling is met 1.189 deelnemers in 2015 een betrekkelijk kleine regeling. Ter vergelijking, de basisbedrijfstoeslagregeling (BBR) heeft circa 50.000 deelnemers.

In de praktijk werkt de Regeling als volgt:

- 1 april-15 mei jaar $\mathrm{x}$ : bij de Gecombineerde opgave geeft de ondernemer aan of hij premiesubsidie wil gaan aanvragen voor BWV, welke percelen hij wil verzekeren en bij welke verzekeraar. ${ }^{20}$

- RVO.nl stuurt de gegevens van de aanvragers door aan de verzekeraars, zodat deze kunnen nagaan of de ondernemers ook daadwerkelijk een aanvraag voor een verzekering hebben gedaan.

- 1 augustus jaar $\mathrm{x}$ : de verzekeraars sturen de voorlopige polissen naar RVO.nl.

- augustus jaar x: RVO.nl maakt een inschatting van de financiële verplichting die RVO.nl moet uitbetalen op basis van de polissen van de verzekeraars, om na te gaan of beschikbare budget voor de premiesubsidie toereikend is.

- september/oktober jaar x: verzekeraars stellen de nota's op voor de premiebetaling;

- oktober/november jaar x: de NVWA controleert in opdracht van RVO.nl de aanvragen bij één verzekeraar op de kwaliteit van de gegevens. De controle van de perceelsoppervlaktes loopt mee met de BBR.

\footnotetext{
${ }^{20}$ Aanmelden na 15 mei kan gedurende een periode van maximaal 25 dagen, maar leidt tot korting op de premiesubsidie van $1 \%$ per werkdag.
} 
- voor 1 november jaar $\mathrm{x}$ : betaling verzekeringspremies door boeren.

- voor 1 november jaar x: verzekeraars sturen definitieve verzekeringsbedragen naar RVO.nl.

- december jaar x: RVO.nl betaalt merendeel van de aanvragen voor premiesubsidie uit aan de verzekeraars, deels aan de ondernemers. ${ }^{21}$

- voor 15 mei van jaar $x+1$ zijn alle premiesubsidies uitbetaald.

- voor 1 juli jaar $x+1$ : herstelbetalingen.

- voor 1 juli jaar $x+2$ : publicatie van de verstrekte subsidies op internet.

- diverse momenten: rapportage aan Brussel.

\subsection{Uitvoeringskosten}

De Regeling is voor RVO.nl relatief eenvoudig uit te voeren, door de koppeling van de deelname aan de Gecombineerde opgave (de jaarlijkse aanlevering van gegevens door agrarisch ondernemers aan RVO.nl) en door de nauwe samenwerking - in de zin van uitwisseling van gegevens - met de verzekeraars. Veel van het werk is geautomatiseerd en kon tot 2015 tegen geringe meerkosten - naar schatting van RVO.nl 'een ton tot ruim een ton' - worden uitgevoerd.

De uitvoering is sinds 2015 voor alle partijen wel gecompliceerder geworden, doordat sinds 2015 de percelen worden geregistreerd waarvoor een verzekering wordt afgesloten. Deze perceelsregistratie is een uitvloeisel van de Europese audit in 2013. Volgens deze audit bestaat het risico dat er meer percelen worden verzekerd dan verzekerd kunnen worden, met het risico dat er te veel subsidie wordt betaald aan de boer. Daarom wordt sinds 2015 gevraagd naar de percelen die worden verzekerd. ${ }^{22}$ Dit betekent meer werk voor de ondernemers, de verzekeraars en RVO.nl. De kosten voor de uitvoering van de Regeling mét perceelsregistratie zijn niet bekend, maar zijn ruw ingeschat op drie ton (mondelinge informatie RVO.nl).

Uit de toelichting op de Regeling in de Staatscourant (2015) blijkt dat de tijd die een ondernemer nodig heeft om de aanvraag te doen wordt geschat op 5 minuten; per polis is de ingeschatte tijd 40 uur voor de verzekeraar. In totaal worden de administratieve lasten bij een gemiddeld aantal deelnemers van 1.200 per jaar ${ }^{23}$ geschat op 10.200 euro per jaar voor ondernemers en verzekeraars.

Uitgaande van de ruwe schatting van 3 ton euro voor de uitvoering door RVO.nl van de BWV in 2015 (inclusief perceelsregistratie), komen de totale lasten van de uitvoering op zo'n 3,1 ton euro. Afgezet tegen de uitgekeerde subsidie van $7,8 \mathrm{mln}$. euro in 2015 , is dat minder dan $5 \%$.

Ter vergelijking, de Uitvoeringsregeling rechtstreekse betalingen GLB (Staatscourant, 2014) geeft aan dat de 'verhoging van de regeldruk die gepaard gaat met deze regelingen wordt geraamd op circa 2.431.000 euro'; dit is exclusief de kosten van RVO.nl voor de uitvoering. De aanvragen voor de rechtstreekse betalingen maken onderdeel uit van de zogenaamde verzamelaanvraag voor Europese steunregelingen. De verzamelaanvraag is een onderdeel van de Regeling landbouwtelling en gecombineerde opgave en volgens deze regeling zijn de samenhangende kosten 4.605.260 euro (exclusief de kosten voor RVO.nl) ((Staatscourant 2016). Afgezet tegen een uitgekeerd subsidiebedrag van $781 \mathrm{mln}$. euro, komen de kosten - exclusief kosten RVO.nl - op zo'n 10\% van het subsidiebedrag.

Er zijn voor zover bekend geen normen voor de hoogte van de uitvoeringskosten van een subsidieregeling, in de zin dat de uitvoeringskosten een bepaald percentage van de uit te keren

\footnotetext{
${ }^{21}$ Sinds 2015 kan de ondernemer ervoor kiezen de premiesubsidie via de verzekeraar te laten lopen, waarbij de verzekeraar een voorschot geeft op de premie en daarmee ook het risico draagt in geval de aanvraag van de ondernemer niet correct is.

${ }^{22}$ Nederland deelt de zienswijze van de EU op dit punt niet, omdat een ondernemer nog altijd $35 \%$ van de verzekeringspremie zelf moet betalen, maar heeft de perceelsregistratie wel geïmplementeerd om eventuele risico's voor het EU-fonds te voorkomen.

${ }^{23}$ Toelichting Staatscourant (2015) Administratieve lasten: 'In 2014 waren er een kleine 800 deelnemers. Verwacht wordt dat deze groeit met de tijd. Indien deze verdubbeld (sic!) in de periode $\mathrm{t} / \mathrm{m}$ 2020, dan is het gemiddeld aantal deelnemers 1.200.
} 
subsidie niet mogen overschrijden. De kosten van de uitvoering van de BWV kunnen daarom niet worden afgezet tegen een vastgestelde norm. Uit de beperkte analyse in de voorgaande alinea's blijkt wel dat de BWV tegen relatief geringe kosten wordt uitgevoerd.

\section{$5.5 \quad$ Beoordeling}

Uit de gesprekken met de verzekeraars en de landbouworganisaties komt in het algemeen een positief beeld naar voren van de wijze waarop RVO. nl de Regeling in nauwe samenwerking met de verzekeraars uitvoert. De relatieve eenvoud van de uitvoering van de Regeling laat onverlet dat er volgens 'het veld' - de verzekeraars en de landbouworganisaties - wel punten zijn in de uitvoering die beter zouden kunnen.

Een voorbeeld is dat het RVO.nI niet lukt alle subsidies uit te betalen voor half december, hoewel dit wel het streven is. Zeker in een jaar met grote schade betekent dit dat de verzekeraar veel voor moet financieren, een voorschot op de subsidies zou dit proces vereenvoudigen. Ook het gegeven dat eventuele kortingen op de premiesubsidie voor de ondernemer door de verzekeraar moeten worden teruggehaald, wordt genoemd als een nadeel van de huidige wijze van uitvoering. Daar staat tegenover dat ondernemers sinds 2015 de nettopremie betalen, wat als een belangrijke stimulans wordt gezien voor de deelname.

Er is niet gekeken naar de optie of een andere uitvoerder de Regeling efficiënter zou kunnen uitvoeren. Dit is minder zinvol omdat Nederland als lidstaat van de EU de Regeling moet uitvoeren conform de eisen van de EU-wetgeving. Dit beperkt de mogelijkheid voor het laten uitvoeren van de BWV door een andere instantie of op een andere wijze.

\subsection{Vergelijking met andere EU-lidstaten}

Binnen de EU is er geen geharmoniseerde aanpak van risicomanagement in de land- en tuinbouw. De wijze waarop risicomanagementinstrumenten zijn ontwikkeld, worden toegepast en gefinancierd verschilt sterk tussen de lidstaten. Onderstaand overzicht van de toepassing van de BWV in andere EU-landen is gebaseerd op een studie over toepassing van risicomanagement- instrumenten in de Europese land- en tuinbouw voor het Europees Parlement. ${ }^{24}$

In de periode 2007-2013 werd via de 1e pijler van het Gemeenschappelijk landbouwbeleid (GLB) op basis van artikel 68 van EU-verordening No 73/2009, lidstaten de mogelijkheid geboden om risicomanagementinstrumenten financieel te ondersteunen. Deze mogelijkheid was eerst beperkt tot de groente- en fruitsector en de wijnsector, maar werd bij de zogenaamde Health Check van het GLB in 2008 opengesteld voor alle sectoren van de land- en tuinbouw. Tot maximaal $10 \%$ van het nationale budget voor de bedrijfstoeslag mocht worden besteed aan het ondersteunen van risicomanagementinstrumenten.

In de periode 2010-2013 heeft de EU via artikel 68 in totaal voor $761 \mathrm{mln}$. euro bijgedragen aan oogstverzekeringen respectievelijk onderlinge fondsen voor dier- en plantenziekten. Het overgrote deel van de financiële bijdrage $(89 \%)$ is besteed aan het subsidiëren van verzekeringspremies.

Slechts een viertal lidstaten, Frankrijk, Italië, Nederland en Hongarije, hebben van deze voorziening gebruik gemaakt. De grootste bedragen uitgekeerd aan Frankrijk (434 mln. euro) en Italië (280 mln. euro). In Frankrijk verving 'artikel 68' een vergelijkbare nationale verzekering. De financiële bijdrage van overheidswege bedroeg een vast percentage van $65 \%$ van het in aanmerking komende

\footnotetext{
${ }^{24}$ IP/B/AGRI/IC/2015-075. PE 573.415 (March 2016) Research for Agri Committe - State of play of risk management tools implemented by member states during the period 2014-2020: national and comparative frameworks. De studie biedt geen informatie over assurantiebelastingen.
} 
deel van de premie (het maximum toegestane percentage binnen de EU-wetgeving) voor gewasverzekeringen. In Italië is in de periode 2010-2013 jaarlijks $70 \mathrm{mln}$. euro uitgegeven om verzekeringen onder artikel 68 te ondersteunen. Dit werd door Dell'Aquila and Cimino (2012) aangemerkt als een significante bijdrage aangezien het overeenkomt met $30 \%$ van de jaarlijkse publieke bijdrage aan de agrarische verzekeringsmarkt in Italië. De bijdrage aan Nederland bedroeg $32 \mathrm{mln}$. euro. Frankrijk is de enige lidstaat geweest die op basis van artikel 68 gebruik heeft gemaakt van onderlinge fondsen.

Bij de hervorming van het GLB in 2013 zijn voor de periode 2014-2020 de risicomanagement instrumenten van het GLB verhuisd naar pijler 2 (plattelandsontwikkeling, EU-verordening No 1305/2013). Binnen pijler 2 zijn drie instrumenten beschikbaar: (1) verzekering van gewas, dier en plant (art. 37); (2) onderlinge fondsen (art. 38) en (3) inkomensstabilisatiefonds (art. 39). De financiële bijdrage van overheidswege met betrekking tot art. 37, 38 en 39 is maximaal $65 \%$ van de totale kosten van de verzekering, waarbij het opbrengstverlies groter moet zijn dan $30 \%$ van de gemiddelde landbouwproductie in de vorige drie jaar of hoger dan het op de vorige vijf jaar gebaseerde driejaargemiddelde waarin de hoogste en de laagste waarde niet in aanmerking worden genomen.

Uit Tabel 5.1 blijkt dat ook binnen pijler 2 het grootste deel van het budget wordt besteed aan het subsidiëren van verzekeringspremies (82\%). Daarnaast blijkt dat binnen het huidige GLB meer lidstaten (10 in plaats van 4) ervoor hebben gekozen om verzekeringspremies vanuit pijler 2 financieel te ondersteunen en dat ook de uitgaven hiervoor toenemen (van $677 \mathrm{mln}$. euro naar $2.213 \mathrm{mln}$. euro). Duidelijk is dat ook de verwachte uitgaven het grootst zijn in Italië en Frankrijk, met respectievelijk 1.397 en $280 \mathrm{mln}$. euro voor de periode 2014-2020.

Tabel 5.1 GLB bijdragen ten behoeven van risico management maatregelen in de land-en tuinbouw in verschillende lidstaten; vergelijking periode $2010-2013$ en $2014-2020^{25}$ in m/n. euro.

\begin{tabular}{|c|c|c|c|}
\hline Periode 2010-2013 & & \multicolumn{2}{|l|}{ Periode 2014-2020 } \\
\hline Pijler 1 & & \multicolumn{2}{|l|}{ Pijler 2} \\
\hline Artikel 68 & & \multicolumn{2}{|c|}{ Plattelandsontwikkelingsprogramma } \\
\hline Frankrijk & 350 & Italië & 1397 \\
\hline Italië & 280 & Frankrijk & 280 \\
\hline \multirow{4}{*}{ Hongarije } & & Nederland & 54 \\
\hline & & Portugal & 53 \\
\hline & & Litouwen & 17 \\
\hline & & Letland & 10 \\
\hline \multirow[t]{7}{*}{ Frankrijk } & 84 & Roemenië & 200 \\
\hline & & Italië & 97 \\
\hline & & Frankrijk & 60 \\
\hline & & Inkomen stabilisatie fonds & 130 \\
\hline & & Italië & 97 \\
\hline & & Hongarije & 19 \\
\hline & & Spanje (Castilla y Leon) & 14 \\
\hline Totaal & 761 & Totaal & 2.700 \\
\hline
\end{tabular}

Bron: IP/B/AGRI/IC/2015-075. PE 573.415 (March 2016); bewerking Wageningen Economic Research.

Binnen de landen die gewasverzekeringen aanbieden behoort Nederland met een verwacht bedrag van $54 \mathrm{mln}$. euro ( $9 \mathrm{mln}$. per jaar gedurende 6 jaar) tot de middenmoot. Van de 12 EU-lidstaten die vanuit pijler 2 risicomanagementinstrumenten financieel ondersteunen maken alleen Spanje en Roemenië

${ }^{25}$ Verwachte uitgaven. 
geen gebruik van een verzekering. Spanje beschikt al jaren over een sterk ontwikkeld verzekeringssysteem gebaseerd op nationale premiesubsidies en heeft geen behoefte om hierin qua financiering veranderingen aan te brengen. In Roemenië is gekozen voor een onderling fonds.

De totale publieke uitgaven van de drie instrumenten bedraagt $2.700 \mathrm{mln}$. euro voor de periode 20142020. Hiervan bedraagt de EU bijdrage vanuit pijler 2 budget $1.701 \mathrm{mln}$. euro (63\%). Tussen de 12 lidstaten verschilt de EU bijdrage vanuit pijler 2 van $98 \%$ voor Frankrijk tot $27 \%$ voor Nederland. Deze $1.701 \mathrm{mln}$. euro is minder dan $2 \%$ van het totale EU-budget van pijler 2 en $0,4 \%$ van het totale GLB 2014-2020 budget. Dit geeft aan dat de ondersteuning vanuit GLB budget voor risico management instrumenten zeer beperkt is.

\subsection{Conclusies}

Op basis van de beschikbare gegevens is de indruk dat de uitvoering door RVO.nl van de Regeling doelmatig gebeurt. Voor een belangrijk deel is dit toe te schrijven aan het feit dat er een goede samenwerking is met de aanbieders van een BWV én aan de mogelijkheid om de Regeling te laten meeliften met de Gecombineerde opgave.

Op basis van de gesprekken met de verzekeraars en de landbouworganisaties rijst in het algemeen een positief beeld op van de wijze waarop RVO.nl de Regeling uitvoert, onverlet een aantal veranderingen die 'het veld' zou willen doorvoeren.

Uit de informatie over de toepassing van risicomanagementinstrumenten in andere EU-lidstaten komt naar voren dat naast Nederland nog 9 lidstaten premiesubsidies geven voor brede weersverzekeringen. Van de 12 EU-lidstaten die vanuit pijler 2 risicomanagementinstrumenten financieel ondersteunen maken alleen Spanje en Roemenië geen gebruik van een verzekering. Spanje beschikt al jaren over een sterk ontwikkeld verzekeringssysteem gebaseerd op nationale premiesubsidies en heeft geen behoefte om hierin qua financiering veranderingen aan te brengen. In Roemenië is gekozen voor een onderling fonds. 


\section{Oogstschadevergoedingen door de overheid}

\section{$6.1 \quad$ Inleiding}

De tweede hoofdvraag van de evaluatie is in welke mate de Regeling ertoe geleid heeft dat het aantal en de omvang van de verzoeken tot oogstschadevergoeding is verminderd. Op basis van empirische gegevens is deze vraag moeilijk te beantwoorden. Sinds de start van de Regeling hebben zich geen weersituaties voorgedaan die hebben geleid tot een breed verzoek tot ex-post publieke oogstschadeloosstelling.

$\mathrm{Er}$ is daarom gekozen voor een aanpak waarbij op basis van een normatieve scenarioanalyse een indicatie wordt gegeven van het effect van de Regeling op lange termijn. Daartoe schetst dit hoofdstuk allereerst een beeld van de historische oogstschadevergoedingen door de overheid. Vervolgens wordt ingegaan op de effecten van de Regeling.

\subsection{Oogstschadevergoedingen in het verleden}

Om een indicatie te kunnen geven van het effect van de Regeling brede weersverzekering op lange termijn, zijn allereerst de belangrijkste niet-verzekerbare schades geïnventariseerd in de periode 1975 tot aan openstelling van de BWV. Het gaat enkel om schades waarbij publieke tegemoetkoming is verleend (voor zover deze gedocumenteerd zijn). De volgende evenementen dienen als uitgangspunt: Rijksgroepenregeling zelfstandigen 1976, twee vorstregelingen (1979 en 1985), Regeling oogstschade Noord-Nederland 1993, Regeling oogstschade Noord-Holland 1994, Wet Tegemoetkoming Schade 1998, Wet Tegemoetkoming Schade 1998, Oogstschaderegeling 1998, Tegemoetkomingsregeling oogstschade 2002, Tegemoetkomingsregeling vorstschade fruitteeltsector 2005 en Tegemoetkomingsregeling sneeuwdrukschade boomkwekerij 2005. In Tabel 6.1 zijn de belangrijkste kenmerken van de regelingen samengevat en vervolgens worden de regelingen beknopt beschreven. De nominale tegemoetkoming door de overheid bedroeg in total circa $429 \mathrm{mln}$. euro voor een tijdsbestek van 35 jaar.

Tabel 6.1 Overzicht regelingen overheid met betrekking tot tegemoetkoming oogstschade in periode $1975-2008$

\begin{tabular}{|c|c|c|c|c|}
\hline Regeling & Jaar & Gevaar & $\begin{array}{l}\text { Schade } \\
(\mathrm{m} / n . \\
\text { euro) a) }\end{array}$ & $\begin{array}{l}\text { Tegemoetkoming } \\
\text { overheid ( } \mathrm{mln} \text {. } \\
\text { euro) }{ }^{1}\end{array}$ \\
\hline \multicolumn{5}{|l|}{ Periode $1973-2008$} \\
\hline Rijksgroepenregeling zelfstandigen & 1976 & droogte & 227 & 131 \\
\hline b) & 1979 & vorst & - & 9 \\
\hline- & 1985 & vorst & 45 & $24 \mathrm{c})$ \\
\hline Regeling oogstschade Noord-Nederland & 1993 & neerslag & - & 3,6 \\
\hline Regeling oogstschade Noord-Holland & 1994 & neerslag & 5 & 2,5 \\
\hline Wet Tegemoetkoming Schade WTS1 & 1998 & neerslag & 210 & 126 \\
\hline Wet Tegemoetkoming Schade WTS2 & 1998 & neerslag & 115 & 82 \\
\hline Oogstschaderegeling OSR & 1998 & neerslag & 118 & 42 \\
\hline Tegemoetkomingsregeling oogstschade & 2002 & neerslag & - & 3,8 \\
\hline Tegemoetkomingsregeling vorstschade fruitteeltsector & 2005 & vorst & - & 5,5 \\
\hline Tegemoetkomingsregeling sneeuwdrukschade boomkwekerij & 2005 & sneeuwdruk & 7 & 3,5 \\
\hline Totaal & & & & 429 \\
\hline
\end{tabular}

a) Niet geïndexeerd; b) - = onbekend; c) Aanname dat 54\% van schade is vergoed, afgeleid van overige tegemoetkomingen. 


\section{Droogteschade 1976}

De schade van de zeer droge zomer in 1976 werd door de aanvragers samen op $227 \mathrm{mln}$. euro geschat. Via de Rijksgroepenregeling zelfstandigen is voor $131 \mathrm{mln}$. euro bijstand verleend. Vooral de rundveehouderij heeft van de droogte te lijden gehad (Van Asseldonk et al., 2000). Ook de jaren 1982 en 1993 staan te boek als extreem droge jaren, maar is er geen compensatie via publieke middelen verleend. De droge zomer in 1982 zorgde vooral in de Noordelijke provincies, IJsselmeerpolders en Limburg voor schade. De omvang van het schadebedrag is niet bekend. Ook over de droogteschade voor de agrarische sector in 1993 zijn geen schadegegevens bekend (Staalduinen et al., 1999).

\section{Vorstschade 1979}

De Nederlandse fruitteelt had in 1979 te kampen met ernstige schade ten gevolge van een langdurige strenge winter. Boomgaarden in Groningen, Friesland en in mindere mate in de Noordoostpolder en in West-Friesland werden getroffen. Het gevolg was zware wildschade in de ondergesneeuwde fruitaanplantingen en takbreukschade door het wegdooien van de sneeuw, waardoor een aantal aanplantingen geheel of gedeeltelijk moest worden gerooid. De wildschade, echter niet de takbreukschade, werd door de overheid vergoed. De uitgekeerde schade werd geraamd op $9 \mathrm{mln}$. euro (Asseldonk et al., 2000).

\section{Vorstschade 1985}

Als gevolg van wintervorstschade in 1985 zijn vele honderden hectaren fruitbomen gerooid of werden in de daaropvolgende jaren gerooid. De totale schade werd begroot op $45 \mathrm{mln}$. euro die deels door de overheid door middel van een speciale regeling werd vergoed (Van Asseldonk et al., 2000).

\section{Neerslagschade 1993}

Als gevolg van overvloedige regen in het Noorden in 1993 werd in het kader van Regeling Oogstschade Noord-Nederland 3,6 mln. euro aan agrarische bedrijven uitbetaald. Van de totale omvang van de schade zijn geen gegevens meer beschikbaar (Van Asseldonk et al., 2000).

\section{Neerslagschade 1994}

In 1994 ontstond in Noord-Holland wateroverlast als gevolg van extreme regenval. De schade bedroeg volgens officiële taxaties $5 \mathrm{mln}$. euro. Door het ministerie van LNV is in het kader van de 'Regeling Oogstschade Noord-Holland' 2,5 mln. euro beschikbaar gesteld als tegemoetkoming in de schade (Staalduinen et al., 1999).

\section{Neerslagschade 1998}

In september 1998 viel de extreme regen, die in Zuidwest-Nederland (Delfland en Zeeland) aanleiding gaf tot wateroverlast, verspreid over twee dagen: 13 en 14 september. Circa $201 \mathrm{mln}$. euro schade is opgetreden in de agrarische sector (LASER, 1998). De hoogte van de tegemoetkoming bedroeg $126 \mathrm{mln}$. euro ('WTS1'). Het noorden en oosten van Nederland (Drenthe, Overijssel, Oost Groningen) kregen op 27 en 28 oktober 1998 ook veel regen, waarbij een enorme hoeveelheid binnen 24 uur viel. Hierdoor kon in de akker- en tuinbouw een deel van de gewassen niet worden geoogst. De getaxeerde teeltschade en vervolgschade is $115 \mathrm{mln}$. euro, waarvan $82 \mathrm{mln}$. euro uitgekeerd is ('WTS2'). In de andere gebieden konden de ondernemers een beroep doen op de Regeling oogstschaderegeling ('OSR'). De oogstschade is getaxeerd op $118 \mathrm{mln}$. euro met een uitgekeerde tegemoetkoming van $42 \mathrm{mln}$. euro (Laser, 1998).

\section{Neerslagschade 2002}

Aanleiding voor het opstellen van de Tegemoetkomingsregeling oogstschade 2002 was de zware regenval in de maand augustus van het jaar 2002. De overheid heeft subsidie verstrekt (in de vorm van garantstelling en schadetegemoetkoming) na het oprichten van een verzekering in 2004 (deelnemers met een schadetaxatie kregen met terugwerkende kracht de schade vergoed rekening houdend met het eigen risico die van toepassing was voor de verzekering). Het gewicht van deze structurele oplossing werd tot uitdrukking gebracht in het feit dat gedupeerde ondernemers ten minste gedurende vijf jaren moesten zijn verzekerd om in aanmerking te komen voor tegemoetkoming van de geleden schade in 2002. Het subsidieplafond van de Regeling bedroeg 3,8 mln. euro (wetten.overheid.nl/BWBR0019496/geldigheidsdatum_01-07-2012 (Wetten.overheid.nl, 2012). 


\section{Vorstschade 2005}

In het voorjaar van 2005 is grote schade opgetreden in met name appel- en perenboomgaarden als gevolg van extreme vorst in de Noordoostpolder, maar ook elders in Flevoland en in de provincies Groningen, Friesland, Drenthe en Noord-Holland zijn fruittelers getroffen. Er waren bedrijven die nog geen $10 \%$ van de normale hoeveelheid aan kilo's aan een boom oogsten. Via de Regeling Vorstschade fruitteeltsector 2005 is circa 5,5 mln. euro subsidie verleend aan 82 aanvragers (LNV, 2009) na het oprichten van een verzekering (conform neerslagschaderegeling) (Rijksoverheid, 2009).

\section{Sneeuwdrukschade 2005}

Op 25 november 2005 werden delen van Oost- en Zuid-Nederland getroffen door zware sneeuwval. In totaal is de schade vastgesteld op 30 bedrijven in Oost-Nederland (Twente, Achterhoek en OostVeluwe) en in Brabant en Limburg. De totaal getaxeerde schade bedroeg circa 7 mln. euro. De overheid heeft een compensatie verstrekt via de Regeling Tegemoetkomingsregeling sneeuwdrukschade boomkwekerij met een omvang van 3,5 mln. euro, na het oprichten van een verzekering (conform neerslagschaderegeling) (Rijskoverheid, 2008).

\subsection{Oogstschade periode 2009-2016}

Sinds de start van de BWV hebben zich een aantal extreme weersituaties voorgedaan (Tabel 6.2). Schade-uitkeringen via de gesubsidieerde BWV worden niet centraal geregistreerd door het Verbond van Verzekeraars omdat er in deze branche zo weinig aanbieders zijn dat openbare cijfers herleid zouden kunnen worden tot individuele verzekeraars.

Tabel 6.2 Overzicht oogstschade in periode 2009-2015

\begin{tabular}{|c|c|c|c|c|}
\hline Oogstschade & Jaar & Gevaar & $\begin{array}{l}\text { Schade } \\
\text { ( } m / n . \\
\text { euro) a) }\end{array}$ & $\begin{array}{l}\text { Tegemoetkoming } \\
\text { overheid }\end{array}$ \\
\hline Geen ad-hoctegemoetkoming overheid & 2009 & Vorst & 6,5 & Premiesubsidie \\
\hline Geen ad-hoctegemoetkoming overheid & 2010 & Neerslag & 25 & Premiesubsidie \\
\hline Geen ad-hoctegemoetkoming overheid & 2015 & Neerslag & b) & Premiesubsidie \\
\hline $\begin{array}{l}\text { Geen ad-hoctegemoetkoming overheid (peildatum 8-7-2016), } \\
\text { boeren kunnen beroep doen op werktijdverkorting }\end{array}$ & 2016 & $\begin{array}{l}\text { Neerslag en } \\
\text { hagel }\end{array}$ & b) & Premiesubsidie \\
\hline
\end{tabular}

a) Niet geïndexeerd; b) Onbekend.

\section{Vorstschade 2009}

De strenge winter begin januari 2009 in Zuid-Nederland met vorst van tot -20,8 graden Celsius heeft vorstschade veroorzaakt in prei en spruiten. Circa 70 telers rapporteerden schade, en in totaal betrof het ruim 500 ha, met een getaxeerd schadebedrag van 6,5 mln. euro (Oonk-Nooren, 2009). LLTB heeft tevergeefs geprobeerd de schade te verhalen bij de overheid. Hoewel de BWV van start is gegaan in 2009 konden gedupeerde telers zich nog niet verzekeren voor dit voorval (dekking ging van start in het voorjaar van 2009).

\section{Waterschade 2010}

In 2010 is met name in de Achterhoek schade als gevolg van de extreme neerslag opgetreden. In een kort tijdsbestek viel $120 \mathrm{~mm}$ tot $180 \mathrm{~mm}$ neerslag. Ook akkerbouwers in het midden van het stroomgebied kregen te maken met de grote hoeveelheid water. Volgens inschattingen van LTO Nederland bedroeg de schade voor het gehele gebied rond de $25 \mathrm{mln}$. euro (Boerenbusiness, 2010).

Vorstschade 2012

Strenge vorst in februari 2012 veroorzaakte voornamelijk schade in de fruitteelt. Telers in Flevoland en de Noordoostpolder hadden het zwaarst te lijden. Maar ook in de Betuwe, Noord-Holland en 
Limburg heeft de vorst schade veroorzaakt. In bijvoorbeeld de perenteelt waren er bevroren onderstammen en bomen met veel vruchtuitval. Niet alleen in 2012 was er schade, maar ook de jaren daarna was er vervolgschade aan de bomen. NFO schat de schade op zeker $85 \mathrm{mln}$. euro. Het betrof een verzekerbaar risico (echter, er is gekozen voor beperkte dekking van vorstschade om de verzekeringstarieven acceptabel te houden) (Gfactueel, 2012).

\section{Waterschade 2015}

Tot wel honderd millimeter water kreeg het Land van Heusden \& Altena op 30 en 31 augustus. Ingeschat is dat waterschade opgetreden is op circa 1.000 ha aardappelen (Boerenbusiness, 2015). In dit getroffen gebied was een redelijk grote groep telers verzekerd.

Waterschade en hagelschade 2016

Extreme regenval in korte tijd in het voorjaar van 2016 en een extreme hagelbui op 23 juni heeft aanzienlijke teeltschade veroorzaakt in Zuidoost-Nederland. De schadeomvang is op moment van het afsluiten van dit onderzoek vooralsnog niet objectief vastgesteld door onafhankelijke taxateurs. Boeren kunnen een beroep doen op werktijdverkorting. De sectorvertegenwoordigers van LLTB en ZLTO hebben het ministerie van EZ verzocht om noodsteun.

\subsection{Conclusies}

Extreme schadegebeurtenissen zijn per definitie zeldzaam en daarmee ook tegemoetkomingsverzoeken. Echter in de korte looptijd sinds openstelling van de Regeling hebben zich een aantal extreme weersituaties voorgedaan, waarbij vanuit de sectorvertegenwoordigers geen verzoek is ingediend voor een ad-hoc publieke tegemoetkoming van de schadelast. Het ministerie van Economische Zaken had een heldere boodschap en kon wijzen op de mogelijkheid van de BWV. De meest recente teeltschade van juni 2016 heeft wel geleid tot een verzoek om tegemoetkoming, tot op heden (juli 2016) is het ministerie van EZ hier niet in meegegaan.

De vorstschade in de fruitteelt in 2012 was een voorval waarbij in het verleden in soortgelijke gevallen tegemoetkoming werd verleend. Als de claim op ad-hocbasis door de overheid zou zijn vergoed dan zou de tegemoetkoming circa $46 \mathrm{mln}$. euro bedragen; dit is op basis van de aanname dat $54 \%$ van de schade is vergoed, welk percentage is afgeleid van overige tegemoetkomingen. Ter vergelijking de jaarlijkse premiesubsidie bedroeg $4,8 \mathrm{mln}$. euro in 2012.

Een andere benadering is om de jaarlijkse premiesubsidie van 7,8 mln. euro in 2015 (Tabel 3.2) te vergelijken met de gemiddelde ad-hoctegemoetkoming voorafgaande aan de openstelling. Zoals eerder weergegeven (Tabel 6.1) bedroeg de gemiddelde nominale tegemoetkoming door de overheid circa $12 \mathrm{mln}$. euro per jaar (totaal circa $429 \mathrm{mln}$. euro voor een tijdsbestek van 35 jaar). 


\section{$7 \quad$ Synthese en discussie}

\subsection{Synthese}

\section{Hoofdvragen}

De evaluatie van de Regeling draait om twee hoofdvragen, namelijk:

1. Is er aan het einde van de looptijd van de Regeling brede weersverzekering voor de periode 20102014 een commercieel aantrekkelijke verzekering voor de verzekeraar en voor de verzekerden, zonder overheidssteun?

2. In welke mate heeft de Regeling ertoe geleid dat het aantal en de omvang van de verzoeken tot schadevergoedingen is verminderd?

Het antwoord op de eerste vraag is nee. Deze conclusie is bevestigd door zowel telers en landbouworganisaties als door verzekeraars. Aan het einde van de looptijd van de eerste regeling zijn er te weinig deelnemers om een commercieel aantrekkelijke verzekering in de markt te zetten. Ondernemers geven als belangrijkste redenen om niet deel te nemen aan dat de premie en het eigen risico van de verzekering te hoog zijn en de dekking te beperkt.

Het antwoord op de tweede vraag is moeilijk objectief vast te stellen op basis van beschikbare empirische gegevens. De verzekering dekt de gevolgen van extreem weer af dat per definitie niet frequent voorkomt. In de korte looptijd sinds openstelling van de Regeling hebben zich niettemin een aantal extreme weersituaties voorgedaan. Daarbij is vanuit de sectorvertegenwoordigers geen verzoek ingediend voor een ad-hoc publieke tegemoetkoming van de schadelast. Het ministerie van Economische Zaken had een heldere boodschap en kon wijzen op de mogelijkheid van deelname aan de BWV.

De meest recente teeltschade van juni 2016 heeft wel geleid tot een verzoek om tegemoetkoming, maar tot op heden (juli 2016) is het ministerie van EZ hier niet in meegegaan.

\section{Overige bevindingen}

\section{Theoretisch kader}

In het in hoofdstuk 2 geschetste theoretische kader is aangegeven dat er verschillende redenen zijn waarom er marktfalen kan optreden, waardoor commerciële verzekeringen niet tot stand komen. Het gaat dan met name om moreel wangedrag (moral hazard), antiselectie en risicobewustzijn.

Het toetsen van de mate van moral hazard en de verandering daarvan is inherent moeilijk. De verzekeraars geven aan dat moral hazard niet een groot knelpunt is gebleken in de afgelopen vijf jaar. Moral hazard wordt enerzijds beperkt door het opnemen van een substantieel eigen risico per verzekerde en anderzijds door het opstellen van acceptatievoorwaarden (via artikel over algemene uitsluitingen). Voorbeelden zijn de beperking van de verzekerde periode, om te voorkomen dat oogsten worden uitgesteld met het risico van neerslagschade; gebruik van drempelwaarden (met name minimale hoeveelheid neerslag per tijdseenheid), en het uitsluiten van teelten in uiterwaarden. De verwachting is dat naarmate meer schadecijfers bekend worden de komende jaren, de verzekeraars hun polisvoorwaarden zullen aanscherpen, en daarmee de kans op moral hazard verder verkleinen.

Wat betreft antiselectie geldt dat deze steeds meer ingeperkt kan gaan worden, naarmate de verzekeraars meer data kunnen vergaren over het optreden van schade. Daardoor wordt het steeds makkelijker om de premies te differentiëren naar gewas, regio en/of neerslaghoeveelheid. Voor hagel zijn er voldoende schadestatistieken. Dat geldt niet voor regen, maar dat is een kwestie van tijd. Premiedifferentiatie kan ook plaatsvinden op grond van al dan niet genomen preventiemaatregelen. 
Het risicobewustzijn onder telers is vaak (te) laag. Ondernemers (net als alle mensen) onderschatten vaak catastrofale risico's en zijn daardoor niet bereid de benodigde risicopremie te betalen. Als gevolg van een geringe vraag is er een te smalle basis voor verzekeringsmaatschappijen om geschikte private verzekeringsproducten te ontwikkelen en aan te bieden. Sinds de openstelling van de Regeling zijn verzekeraars actief om potentiële klanten te wijzen op risico's en ieder jaar wordt ondernemers bij het invullen van de Gecombineerde opgave de vraag gesteld of ze (willen) deelnemen.

De theoretische veronderstelling dat verzekerde ondernemers zich meer kunnen specialiseren wordt ondersteund door de gegevens over fruitbedrijven, waar het aandeel appel en peer wat groter is op verzekerde bedrijven dan op niet-verzekerde bedrijven. De gegevens over de bedrijven met akkerbouwgewassen ondersteunen de veronderstelling niet. De bedrijven met een BWV zijn gemiddeld gesproken groter dan de bedrijven zonder een BWV.

Het 'crowding out'-effect, waarbij de overheidssubsidie een private verzekering verdringt, wordt bevestigd. Uit de enquête die is gehouden onder ondernemers blijkt dat bijna $80 \%$ van de ondernemers met een BWV, een hagelverzekering had voordat ze een BWV afsloten. Het gaat zowel om fruittelers als bedrijven met akkerbouwgewassen.

\section{Bereik, doeltreffendheid, doelmatigheid}

De aannames van de overheid bij het opstellen van de Regeling dat in een periode van vier jaar alle openteeltondernemers een BWV zouden hebben en iedere deelnemer zijn gehele areaal met alle gewassen zou verzekeren, zijn niet bewaarheid. Daarmee blijft het bereik van de Regeling achter bij het gestelde doel, dat overigens nogal ambitieus was.

Voor ondernemers is de belangrijkste reden om een BWV af te sluiten het feit dat dit de enige manier is om vanuit de overheid bij verzekerbare gewasschade nog een vergoeding te krijgen, zo bleek uit de enquête. De mogelijkheid om specifieke gewassen te verzekeren en het feit dat de subsidie sinds 2015 direct in mindering wordt gebracht op de te betalen premie, zijn eveneens belangrijke beweegredenen voor het afsluiten van de verzekering.

Het doel om commercieel aantrekkelijke verzekeringen voor de verzekeraar en voor de agrarische ondernemingen tot stand te brengen, is niet bereikt. Het doel om het aantal verzoeken tot schadevergoeding aan het ministerie van EZ te verminderen is wel gehaald, uitgezonderd de meest recente teeltschade in juni 2016.

Op basis van de beschikbare gegevens is de indruk dat de uitvoering door RVO.nl van de Regeling doelmatig gebeurt. Voor een belangrijk deel is dit toe te schrijven aan het feit dat er een goede samenwerking is met de aanbieders van een BWV én aan de mogelijkheid om de Regeling te laten meeliften met de Gecombineerde opgave.

De lasten voor de overheid in geval er geen Regeling zou zijn geweest in de periode 2010-2014, worden geschat op $46 \mathrm{mln}$. euro, gebaseerd op de vorstschade in de fruitteelt in 2012. Dit was een voorval waarbij in het verleden in soortgelijke gevallen tegemoetkoming werd verleend. Ter vergelijking: de jaarlijkse premiesubsidie bedroeg 4,8 $\mathrm{mln}$. euro in 2012 . De geschatte uit te betalen ad-hocschadevergoeding is ook aanzienlijk meer dan de verstrekte premiesubsidie in de periode 20102014 (23 mln. euro).

Een andere benadering is om de jaarlijkse premiesubsidie van 7,8 mln. euro in 2015 te vergelijken met de gemiddelde ad-hoctegemoetkoming voorafgaande aan de openstelling. Deze bedroeg gemiddeld nominaal circa $12 \mathrm{mln}$. euro per jaar (totaal circa $429 \mathrm{mln}$. euro voor een tijdsbestek van 35 jaar). Ook in dat perspectief is de steun voor de Regeling doelmatig geweest. 


\subsection{Discussie}

Verdere groei deelname mogelijk

Tegen de achtergrond van bovenstaande conclusies mag verwacht worden dat het aantal deelnemers aan een BWV nog kan toenemen. Dat geldt vooral voor de akkerbouw waar de deelnamegraad een stuk lager ligt dan bij fruittelers. De verwachte verandering van neerslagpatronen als gevolg van klimaatverandering, en de publiciteit daaromtrent, zullen naar verwachting ook bijdragen aan een grotere deelname.

Bij fruittelers lijkt de groei in het aantal deelnemers eruit te zijn. Fruittelers kunnen de belangrijkste schadepost in de fruitteelt voorkomen met behulp van hagelnetten, een toenemend aantal fruittelers maakt hiervan gebruik.

Vanuit het perspectief van de ondernemer is verzekeren een rationele stap. Ondernemen gaat gepaard met het nemen van risico's. Echter, een ondernemer zal vooral risico's met een lage frequentie en een grote omvang willen overdragen om de continuïteit van het bedrijf niet in gevaar te brengen. Met betrekking tot teeltrisico's zijn deze sinds de openstelling van de regeling over te dragen via het afsluiten van een brede weersverzekering. Verzekeringen maken diversificatie (bijvoorbeeld meerdere gewassen en locaties) als strategie voor risicospreiding minder noodzakelijk. Verzekerde ondernemers kunnen zich dus meer specialiseren, wat efficiencywinst en schaalvoordelen oplevert. Zij hoeven zich minder zorgen te maken over de gevolgen van zo'n calamiteit voor het bedrijf. Samenvattend: het verzekeren van calamiteiten faciliteert bedrijfsontwikkeling van het landbouwbedrijf en zorgt voor gemoedsrust van de teler.

\section{Mogelijke aanpassingen in de BWV}

Uit de enquête die is gehouden onder ondernemers kwam naar voren dat de beperkte dekking van de verzekering, de hoogte van het eigen risico en de hoogte van de premie de belangrijkste redenen zijn om geen BWV af te sluiten.

Met het opbouwen van schadestatistieken door de verzekeraars, kan er meer differentiatie komen in de premies, zowel naar regio, gewas als genomen preventiemaatregelen. Hierdoor kunnen premies beter toegesneden worden op de bedrijfssituatie. Voor dit onderzoek was het niet mogelijk na te gaan in welke mate premiedifferentiatie al bestaat en wordt toegepast, omdat de verzekeraars geen inzicht hierin geven. Dit belemmert de diepgang van de evaluatie, omdat evenmin nagegaan kan worden in hoeverre premies al zijn aangepast aan gebieden waar meer dan gemiddeld neerslag of hagel valt of droogte is.

Het verplicht stellen van deelname aan de BWV is een mogelijkheid om de regeling commercieel aantrekkelijk te maken. Echter, bij het opzetten van de regeling is gebleken dat telers en landbouworganisaties geen voorstander zijn van verplichtstelling. Ook is deze aanpassing moeilijk wettelijk te regelen zonder grote inspanningen.

Wat als ...

De respondenten in dit onderzoek geven aan dat het wegvallen van de premiesubsidie zal leiden tot een terugkeer naar de situatie voor de premiesubsidie. Dat wil ook zeggen dat de hagelverzekering weer in de plaats komt van de BWV.

Denkbaar is dat de verzekeraars voor de akkerbouw opnieuw een regenverzekering in de markt zullen zetten. Sinds de vorige regenschadeverzekering uit 2004 zijn immers ruim tien jaar verstreken waarin data konden worden verzameld over regenschade. Dit maakt het mogelijk een fijnmaziger regeling op te zetten. Echter de deelname zal vermoedelijk heel beperkt zijn, zoals ook al is gebleken bij de voorloper van de BWV, omdat de premie door veel ondernemers als te hoog zal worden bevonden. Regenschade bij akkerbouwgewassen komt vaker en grootschaliger voor dan hagelschade, waardoor de premie voor de regenverzekering veel hoger moet liggen dan voor een hagelverzekering.

De verwachting van de verzekeraars is dat bij afbouw van de premiesubsidie de transactiekosten, het risico en het premietarief gelijk blijven, maar de premie voor de ondernemer zal toenemen. Voor veel 
verzekerde telers is de subsidie een belangrijke drijfveer. Indien deze verdwijnt is de verwachting dat maar weinig telers een verzekering zullen blijven afsluiten.

Zonder verplichte deelname of premiesubsidie zal het aantal verzekerden te klein zijn vanwege de hoge premie. Bij het ontbreken van een adequate premiedifferentiatie zullen alleen díe ondernemers een verzekering afsluiten die daadwerkelijk meer risico lopen. Alleen als de verzekering verplicht wordt voor alle open teelten in Nederland, speelt het probleem van de antiselectie niet.

\subsection{Aanbevelingen}

De deelname aan de huidige BWV heeft de laatste jaren een groeisprong laten zien en zal naar verwachting nog verder kunnen groeien de komende jaren. Daarbij is de veronderstelling dat de overheid de premiesubsidie handhaaft (65\% subsidie op de verzekeringspremie) en geen noodsteun verleent in geval van verzekerbare schade. Een substantiële deelname aan de BWV is een vereiste voor een concurrerend aanbod van verzekeraars.

Het doorzetten van dit overheidsbeleid heeft als voordeel dat de verzekeringsmarkt de komende jaren nog beter in staat zal worden gesteld om premies te differentiëren naar gewas en locatie. Ook kan dan verder worden gewerkt aan het inbouwen van prikkels ten behoeve van risicopreventie op het agrarische bedrijf. Daarnaast zou bevorderd kunnen worden dat waterschappen en lokale overheden in samenwerking met ondernemers maatregelen nemen om het risico voor wateroverlast op het bedrijf te verminderen.

Uitgaande van een groeiende deelname, zal bij een gelijkblijvende overheidssubsidie ( 9 mln. euro per jaar), het subsidiepercentage verlaagd moeten worden. Eventuele onzekerheid over de hoogte van het subsidiepercentage kan ten koste gaan van draagvlak onder (potentiële) verzekerden. Mogelijkheden om dit te voorkomen zijn:

- ophogen premiesubsidiebedrag door herallocatie van EU-middelen (in overleg met de sector), al dan niet in combinatie met een aanpassing van de hoogte van de assurantiebelasting

- vooraf bekend maken van subsidiepercentage in plaats van subsidiebedrag

- strikter hanteren dat het een calamiteitendekking betreft met 30\% eigen risico per gewasblok, waardoor de risicopremie en daarmee het subsidiebedrag omlaag $\operatorname{kan}^{26}$

- subsidiebedrag differentiëren naar te verzekeren gevaar, om zo 'crowding out' van reguliere hagelverzekeringsproducten te voorkomen.

Over enkele jaren zou opnieuw geëvalueerd kunnen worden of de BWV op eigen benen kan staan, dan wel er mogelijkheden zijn het subsidiebedrag te verminderen omdat de verzekeringsmarkt zich verder heeft ontwikkeld. Het verdient aanbeveling om de premies per gewas en per perceel te registreren en toegankelijk te maken, zodat de toekomstige evaluator de ontwikkelingen in de markt voor BWV kan volgen en beoordelen.

\footnotetext{
${ }^{26}$ Hantering van een eigen risico per hectare is een optie om de deelname aan de BWV aantrekkelijker te maken, maar zal ook leiden tot een hogere verzekeringspremie.
} 


\section{Literatuur en websites}

Asseldonk, M. van, M. Meuwissen en R. Huirne (2000). Risicofinanciering van oogstschade door extreme weersomstandigheden. IRMA-Wageningen UR, Wageningen

Asseldonk, M. van, W. Baltussen en R. Huirne (2009). 'Het gebruik van risico-instrumenten in de landbouwsector en de rol van de overheid'. In ESB, 94, 50 - 55

Asseldonk, M. van, R. Bergevoet, N. Bondt, en H. van der Meulen (2014). Ex-ante raamwerk overheid bij rampen en calamiteiten in de land- en tuinbouw. LEI Wageningen UR, Den Haag

Bator, F.M., (1958). 'The Anatomy of Market Failure'. In: The Quarterly Journal of Economics 72(3): 351-379

Boerenbusiness (2010). 'Achterhoek gedupeerd. Akkerbouwers: 800.000 euro waterschade'. Redactie Boerenbusiness, 16 september 2010

Boerenbusiness (2015). http://www.boerenbusiness.nl/akkerbouw/artikel/10865511/waterschapfrustreert-verzopen-aardappeltelers

Bureau Bartels (2007). Evaluatie Regenverzekering, Hoofdrapport. Amersfoort

Dell'Aquila C. en O. Cimino (2012). Stabilization of farm income in the new risk management policy of the EU: A preliminary assessment for Italy through FADN data. Paper presented at $126^{\text {th }}$ EAAE Seminar, June 27-29, 2012, Capri, Italy

EZ (Ministerie van Economische Zaken) (2016). Probleemstellende notitie Evaluatie Brede Weersverzekering 2010-2020. Den Haag

Gfactueel (2016). http://www.gfactueel.nl/Fruit/Nieuws/2012/9/OFH-Mogelijk-onvoldoende-dekkingvorstschade-1061840W/

IP/B/AGRI/IC/2015-075. PE 573.415 (March 2016) Research for Agri Committe - State of play of risk management tools implemented by member states during the period 2014-2020: national and comparative frameworks

Krugman, P., R. Wells en A. Myatt, (2006). Microeconomics. Canadian Edition. Worth Publishers

LASER (1998). Tegemoetkoming oogstschade 1998

LNV (Ministerie van Landbouw, Natuurbeheer en Visserij) (2009). Vorstschade 2005. Brief aan de Tweede Kamer, kenmerk: DL, 2009/583

OESO (2009). Managing Risk in Agriculture: A Holistic Approach. OECD, Paris

OFH (2016). OFH-Toelichting brede weersverzekering 2016. Via website www.ofh.nl

Oonk-Nooren, K. (2009). '100 \% vorstschade in prei en spruiten'. In: Boerderij, 20 feb 2009

Rijksbegroting (2016). Rijksbegroting 2016, XIII Economische Zaken. Tweede Kamer, vergaderjaar 2015-2016, 34300 XIII, nr. 1 
Rijksoverheid (2008). http://www.rijksoverheid.nl/documenten-en-

publicaties/kamerstukken/2008/11/12/tegemoetkomingsregeling-sneeuwdrukschade-

boomkwekerij.html

Rijksoverheid (2009). http://www.rijksoverheid.nl/documenten-enpublicaties/kamerstukken/2009/03/19/vorstschade-2005.html

Staalduinen, L.C., L. Beumer, G. Eduard en P.J.G.J. Hellegers (1999). Startnotitie 'prijs van waterbeheer'. LEI \& NEI, Den Haag

Staatscourant (2014). Regeling van de Staatssecretaris van Economische Zaken van 11 december 2014, nr. WJZ/14194346, houdende de uitvoering van het gemeenschappelijke landbouwbeleid voor wat betreft de rechtstreekse betalingen en het randvoorwaardenbeleid (Uitvoeringsregeling rechtstreekse betalingen GLB). 16 december 2014, NR. 36127

Staatscourant (2015). Regeling van de Staatssecretaris van Economische Zaken van 21 januari 2015, nr. WJZ/14170735, houdende regels tot het subsidiëren van de premie voor een brede weersverzekering (Regeling brede weersverzekering). 23 januari 2015, Nr. 2276

Staatscourant (2016). Regeling van de Staatssecretaris van Economische Zaken van 1 maart 2016, nr. WJZ/16016391, tot instelling van een landbouwtelling en tot het aanbieden van een gecombineerde opgave (Regeling landbouwtelling en gecombineerde opgave 2016). 3 maart 2016, Nr. 11633

VvV (Verbond van Verzekeraars) (2013). Agrarische verzekeringen vanaf 1995 tot heden. Interne notitie. Den Haag

Wetten.overheid.nl (2012). http://wetten.overheid.nl/BWBR0019496/geldigheidsdatum_01-07-2012 


\section{Bijlage 1 Agrarische verzekeringen}

Deze bijlage geeft een beknopt overzicht van verschillende agrarische verzekeringen sinds 1995 . Dit overzicht is gebaseerd op een notitie van het Verbond van Verzekeraars (VvV, 2013), aangevuld met informatie van de websites van de aanbieders van de verzekeringen.

1995 Q-pol U.A.

In 1995 leidde de uitbraak van Thrips palmi tot de oprichting van de Onderlinge Waarborgmaatschappij (OWM) Q-pol U.A. Deze onderlinge bleek niet levensvatbaar, volgens de uitvoerende partij omdat slechts 150 glastuinders potentieel geïnteresseerd waren in deze verzekering, terwijl er enkele duizenden verzekerden nodig waren om voldoende draagvlak te genereren. In 1999 is de OWM Q-pol geliquideerd en de OWM Fyto U.A. op aandelen opgericht. Deze OWM Fyto U.A. was evenmin succesvol en is in 2002 gestopt. Sindsdien worden de (on)mogelijkheden van een plantgezondheidsfonds verkend.

\section{Avipol}

De Onderlinge Waarborgmaatschappij Avipol B.A. is in 1996 opgericht op initiatief van de kring Vermeerderaars. Het doel is om pluimveebedrijven met vleeskuikenouderdieren de mogelijkheid te bieden zich te verzekeren tegen de risico's van Salmonella. In de jaren daarna is de polis uitgebreid met een dekking tegen schade veroorzaakt door de ziekte Mycoplasma gallisepticum (Mg) en de aandoeningen Hysterie en Schijnleg.

Avipol is nog steeds succesvol, met een marktaandeel van ongeveer $80 \%$. De premie is betrekkelijk laag omdat de schadelast laag is. In de loop der jaren is de regelgeving rondom Salmonella veranderd, en daarmee ook de verzekeringsdekking van Avipol. In 2011 is geprobeerd om de gevolgen van AI-uitbraak (Vogelgriep) te verzekeren, gebruikmakend van premiesubsidie uit GLB Artikel 68. Hiervoor bleek onvoldoende draagvlak in de sector.

Omdat het een 'onderlinge' verzekering is zijn de leden/verzekerden aansprakelijk voor de resultaten van Avipol. De aansprakelijkheid is beperkt tot maximaal vier extra jaarpremies (www.avipol.nl).

\section{PotatoPol}

PotatoPol is in 1997 opgericht op initiatief van LTO Nederland in samenwerking met de Nederlandse Akkerbouw Vakbond. PotatoPol verzekert het risico van financiële schade door het onvoorzien optreden van bruinrot-, ringrot- en PSTVd-besmettingen in aardappelen. PotatoPol verzekert op onderlinge grondslag en heeft geen winstoogmerk. Iedere aardappelteler in Nederland kan lid worden van PotatoPol.

In 2015 telde PotatoPol 3.104 leden. Het verzekerde areaal aardappelen was ruim 99.000 ha, dat is circa $56 \%$ van het areaal aardappelen in Nederland. De waarde van de in verzekering gegeven stammenteelt, pootaardappelen, consumptieaardappelen en zetmeelaardappelen was in totaal $622 \mathrm{mln}$. euro. Vanwege de catastrofale aard van het risico en de kans op besmetting door anderen, waar weinig preventieve maatregelen voor lijken te bestaan, is deze verzekering zeer succesvol (www.potapol.nl).

\section{Porcopol}

Porcopol is in 2003 opgericht om zeugenbedrijven te kunnen verzekeren tegen de financiële gevolgen van de ziekte van Aujeszky. Later kwam daar een verzekering bij voor de kosten van leegstand na een ruiming wegens mond-en-klauwzeer of varkenspest. In 2012 is de verzekering stopgezet, vanwege tanende belangstelling. Betere bedrijfshygiëne, monitoring en herstructurering van de varkenshouderij hebben bovendien de kans op een uitbraak aanzienlijk teruggebracht. 


\section{Regenschadeverzekering}

Telers in voornamelijk West Noord-Brabant werden in augustus 2002 getroffen door zware regenval, waardoor een groot areaal akkerbouwgewassen en vollegrondsgroenten verloren is gegaan. Telers, die voor de gewasschade in 2002 een compensatiebedrag ontvingen, moesten zich minimaal 5 jaar tegen gewasschade door extreme regenval verzekeren. AgriVer en AquaPol boden de regenverzekering aan, de overheid nam deel door het verstrekken van herverzekeringscapaciteit.

Vanwege de betrokkenheid van de overheid werd de verzekering door de Europese Commissie getypeerd als een vorm van staatssteun, met als gevolg een hoog eigen risico.

De regenschadeverzekering is geen succes geweest. Na afloop van de verplichte 5 jaar haakten veel verzekerden af. In totaal tekenden niet meer dan circa 800 akkerbouwers in, terwijl het potentieel om meer dan tienduizend telers ging. In een evaluatie van de regenverzekering werd het beperkte bereik toegeschreven aan een combinatie van factoren, waaronder de hoogte van de premie, het hoge eigen risico ( $25 \%$ van het verzekerde bedrag per gewas) en de mogelijke naheffingen (Bureau Bartels, 2007). Soortgelijke verzekeringen zijn ook opgericht na de vorstschade en sneeuwschade in respectievelijk $2005^{27}$.

\section{Ovopol}

Deze verzekering werd opgericht ten behoeve van de leghennenhouderij. Het oogmerk van de verzekering was het opvangen van de financiële gevolgen van residuen in eieren. Dit probleem werd groter vanwege de nultolerantie op residuen van antibiotica. De onderlinge verzekeraar is opgericht, maar direct daarna weer opgeheven vanwege het ontbreken van voldoende draagvlak.

\section{Hagelverzekeringen}

De verzekering tegen hagelschade bestaat sinds lange tijd en biedt dekking tegen schade als gevolg van hagel. Er zijn verschillende aanbieders van een hagelverzekering (zie paragraaf 5.1).

\footnotetext{
${ }^{27}$ Zie paragraaf 6.2 .
} 


\section{Bijlage 2 Bedrijven met en zonder BWV}

Door RVO.NL zijn gegevens op bedrijfsniveau verstrekt van bedrijven met en zonder BWV. Hiervoor is een selectie gemaakt van bedrijven op basis van de aanwezigheid van bepaalde gewassen, omdat het niet mogelijk was een selectie te maken op basis van bedrijfstype.

De gewas(groepen) die zijn aangevraagd zijn:

- opengrondsgroenten

- fruitteelt

- bloembollenteelt

- bloemkwekerij

- grasland en snijmais

- zaadteelt

- consumptieaardappelen, pootaardappelen, zetmeelaardappelen, suikerbieten en zaaiuien.

Voor de opengrondstuinbouwsectoren was het totaal areaal in een subsector zoals fruitteelt, bloembollenteelt beschikbaar in de RVO.nl-database. Voor akkerbouw was dit niet het geval in de database van RVO.nl. Van de akkerbouwgewassen: aardappelen, suikerbieten, zaaiuien is het areaal opgevraagd. Vervolgens zijn bedrijven ingedeeld op basis van de gewasarealen. Als het areaal aardappelen + suikerbieten + zaaiuien groter is dan het areaal van de overige aangevraagde gewassen dan is het bedrijf ingedeeld als akkerbouwbedrijf.

Figuren op basis van data RVO.NL

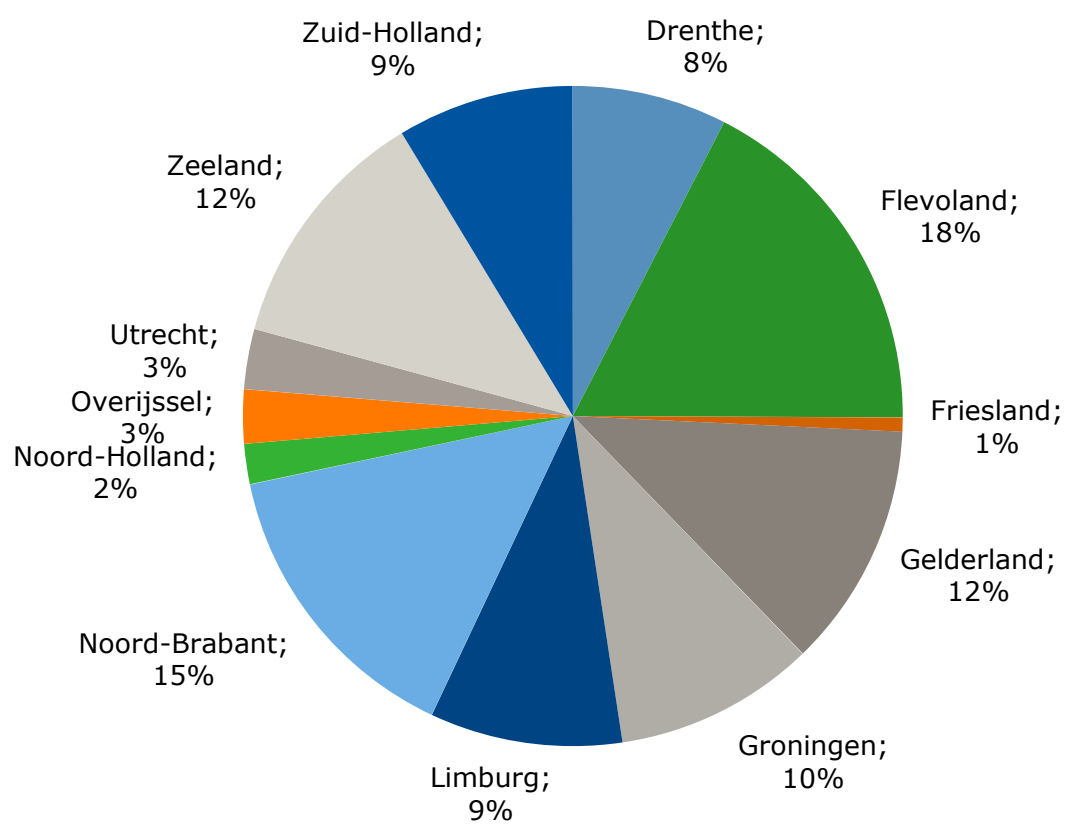

Figuur B2.1 Verdeling van bedrijven met een Brede weersverzekering over provincies, 2015 Bron: RVO.NL, bewerking Wageningen Economic Research. 


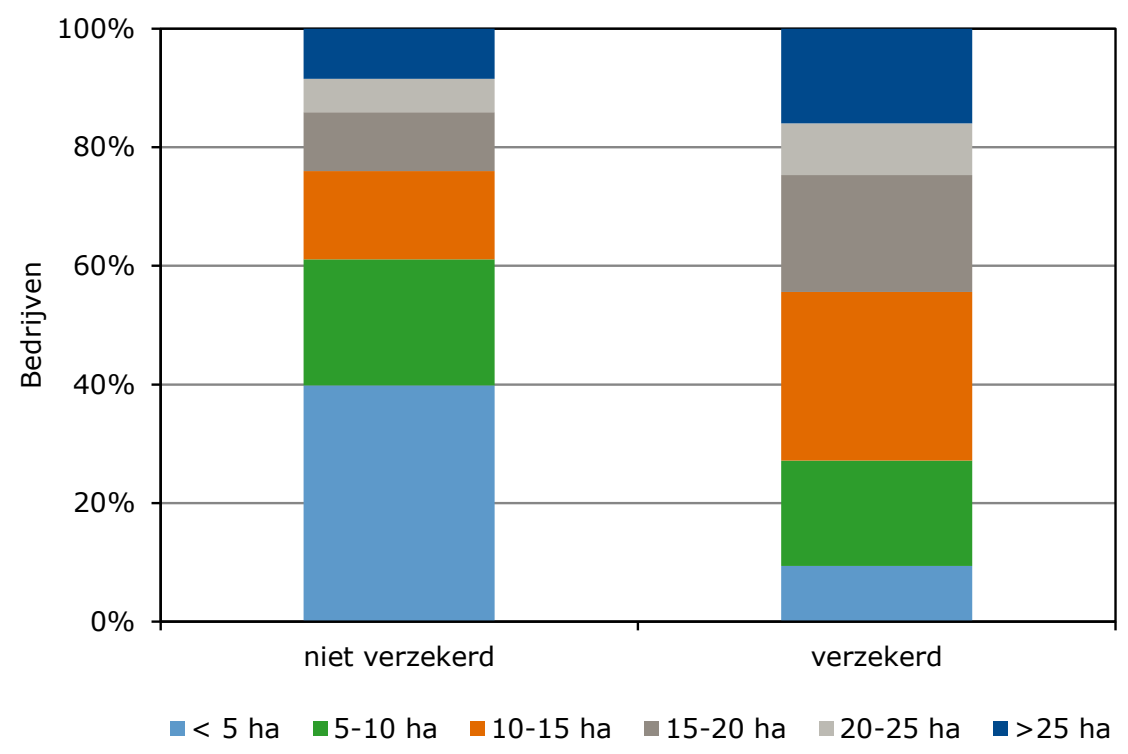

Figuur B2.2 Verdeling van fruitteeltbedrijven naar bedrijfsomvang (ha cultuurgrond) en wel of niet verzekerd, 2015

Bron: RVO.NL, bewerking Wageningen Economic Research.

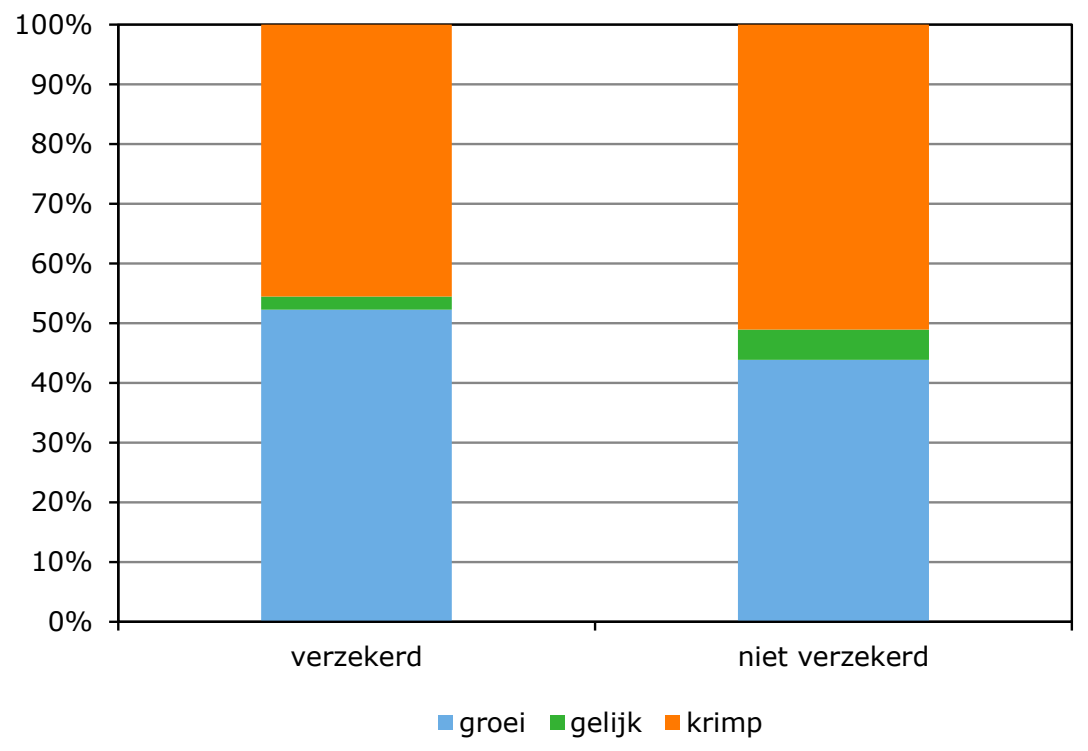

Figuur B2.3 Aandeel fruitbedrijven (\%) naar ontwikkeling areaal cultuurgrond 2007-2015, naar wel/ niet verzekerd

Bron: RVO.NL, bewerking Wageningen Economic Research. 


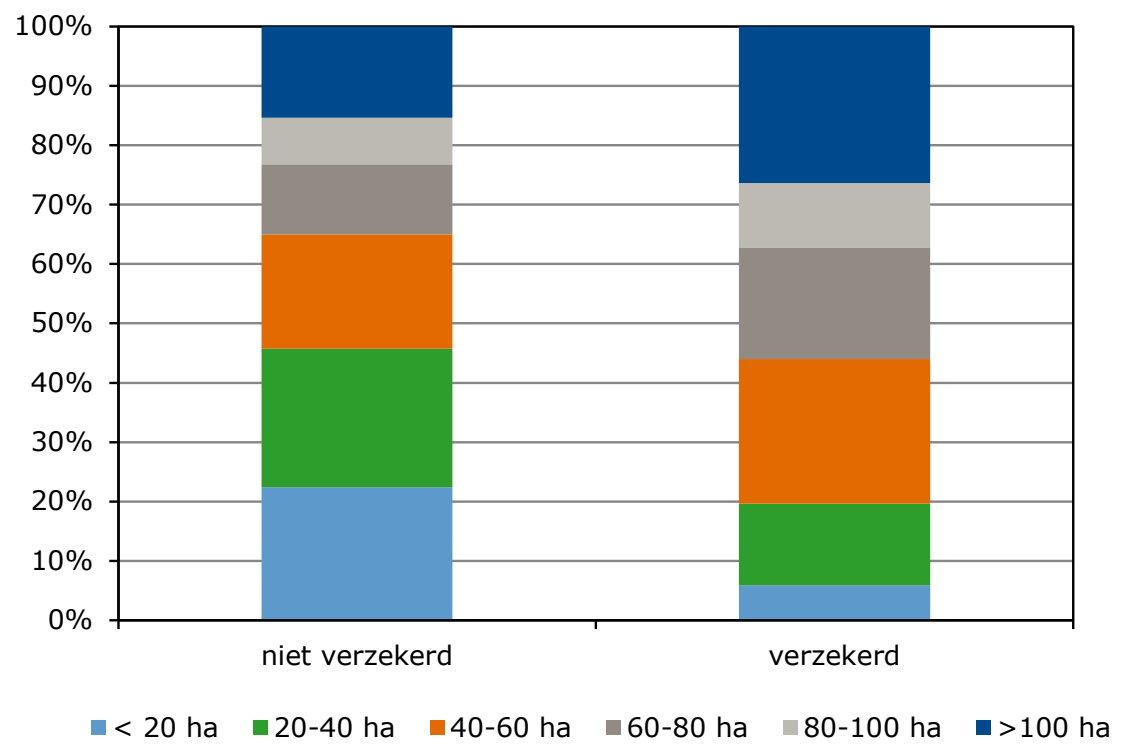

Figuur B2.4 Verdeling van akkerbouwbedrijven naar bedrijfsomvang (ha cultuurgrond) en wel/niet verzekerd, 2015

Bron: RVO.NL, bewerking Wageningen Economic Research.

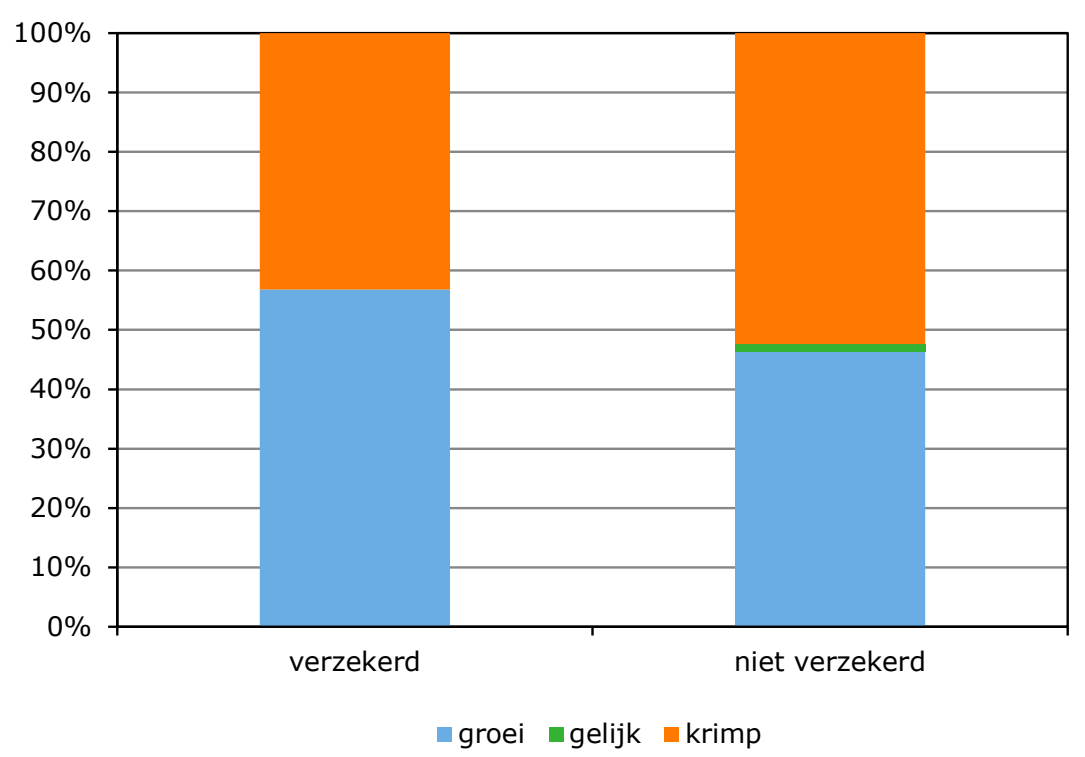

Figuur B2.5 Aandeel akkerbouwbedrijven (\%) naar ontwikkeling areaal cultuurgrond 2007-2015, naar wel/niet verzekerd

Bron: RVO.NL, bewerking Wageningen Economic Research. 


\section{Bijlage 3 Enquête agrarische ondernemers}

\section{Opzet en respons}

$\mathrm{Er}$ is een enquête verstuurd naar alle ondernemers met een BWV in 2015 waarvan het emailadres bekend is, namelijk 1.090 adressen. Op basis van de uitkomsten van de analyses van de RVO.NL-data naar de verdeling van de deelnemers aan de BWV over de sectoren, zijn 1.000 mailadressen geselecteerd van bedrijven zonder verzekering.

Van de enquêtes is 35\% verstuurd naar fruittelers, 51\% naar akkerbouwers en 15\% naar bedrijven met grasland en snijmais. Na het versturen van de enquêtes is eenmalig een herinnering gestuurd. In totaal zijn er 511 enquêtes geheel of gedeeltelijk ingevuld (24\%).

Ondernemers met een verzekering hebben in hogere mate gerespondeerd dan ondernemers zonder een verzekering. De respondenten bestaan voor ongeveer $70 \%$ uit ondernemers met een verzekering. Dit geldt ook voor de sectoren akkerbouw en fruitteelt.

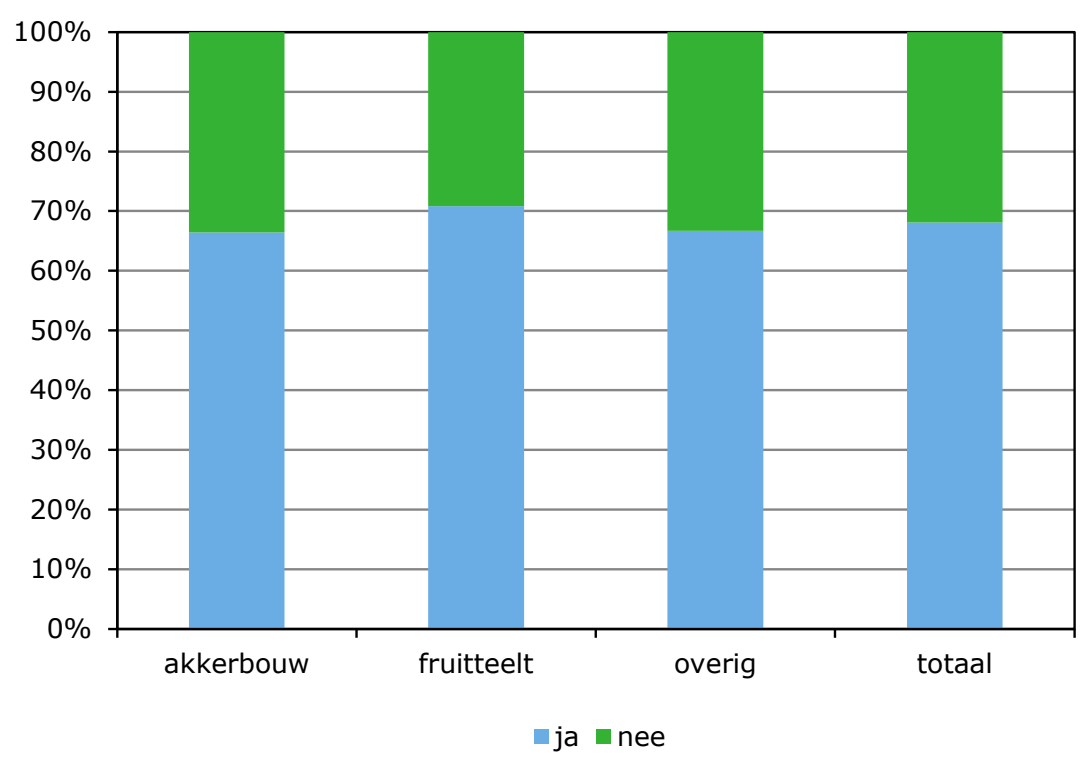

Figuur B3.1 Respons naar sector en wel/niet verzekerd (\%) Bron: enquête Wageningen Economic Research.

De verdeling van de respondenten over de sectoren was ongeveer gelijk verdeeld over de wel/niet verzekerden.

Tabel B3.1 Verdeling respondenten (\%) naar sector en wel/niet verzekerd in 2015

\begin{tabular}{lcc} 
Sector & Wel $(\mathrm{n}=348)$ & Niet $(\mathrm{n}=163)$ \\
Akkerbouw & 49 & 53 \\
\hline Fruitteelt & 39 & 34 \\
\hline Overig & 11 & 12 \\
\hline Totaal & 100 & 100 \\
\hline
\end{tabular}

Bron: enquête Wageningen Economic Research. 
De verdeling over de provincies van de respondenten met een verzekering komt behoorlijk goed overeen met de verdeling gebaseerd op de RVO.NL-data (zie Tabel B3.2).

Tabel B3.2 Ondernemers met een BWV naar provincie (\%) op basis van RVO.NL en enquête

\begin{tabular}{lccc} 
Provincie & Enquête & RVO.nl & 8 \\
Drenthe & 8 & 18 \\
\hline Flevoland & 12 & 1 & 12 \\
\hline Friesland & 2 & 10 \\
\hline Gelderland & 16 & 9 \\
\hline Groningen & 6 & 9 \\
\hline Limburg & 9 & 15 \\
\hline Noord-Brabant & 15 & 2 \\
\hline Noord-Holland & 3 & 3 \\
\hline Overijssel & 2 & 3 \\
\hline Utrecht & 3 & 12 \\
\hline Zeeland & 16 & 9 \\
\hline Zuid-Holland & 7 & 100 \\
\hline Totaal & 100 & & \\
\hline
\end{tabular}

Bron: enquête Wageningen Economic Research.

In tegenstelling tot de RVO.nl-data is er in de enquête geen duidelijk verschil in bedrijfsomvang van respondenten met en zonder verzekering in de akkerbouw en een beperkt verschil in de fruitteelt.

Tabel B3.3 Areaal cultuurgrond per bedrijf (in ha) naar sector en naar wel en niet verzekerden

\begin{tabular}{lccc} 
Sector & Wel & Niet & 77 \\
Akkerbouw & 78 & 77 \\
\hline Fruitteelt & 21 & 18 \\
\hline
\end{tabular}

Bron: enquête Wageningen Economic Research. 
Algemeen

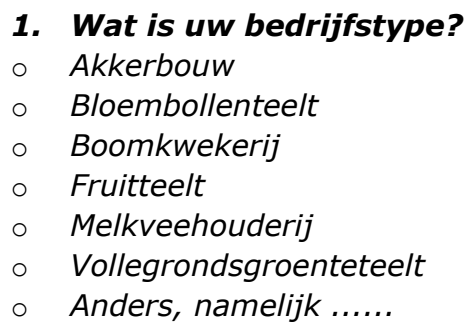

2. Wat is het totale areaal cultuurgrond op uw bedrijf in 2015 ?

Het totale areaal bedraagt .... ha

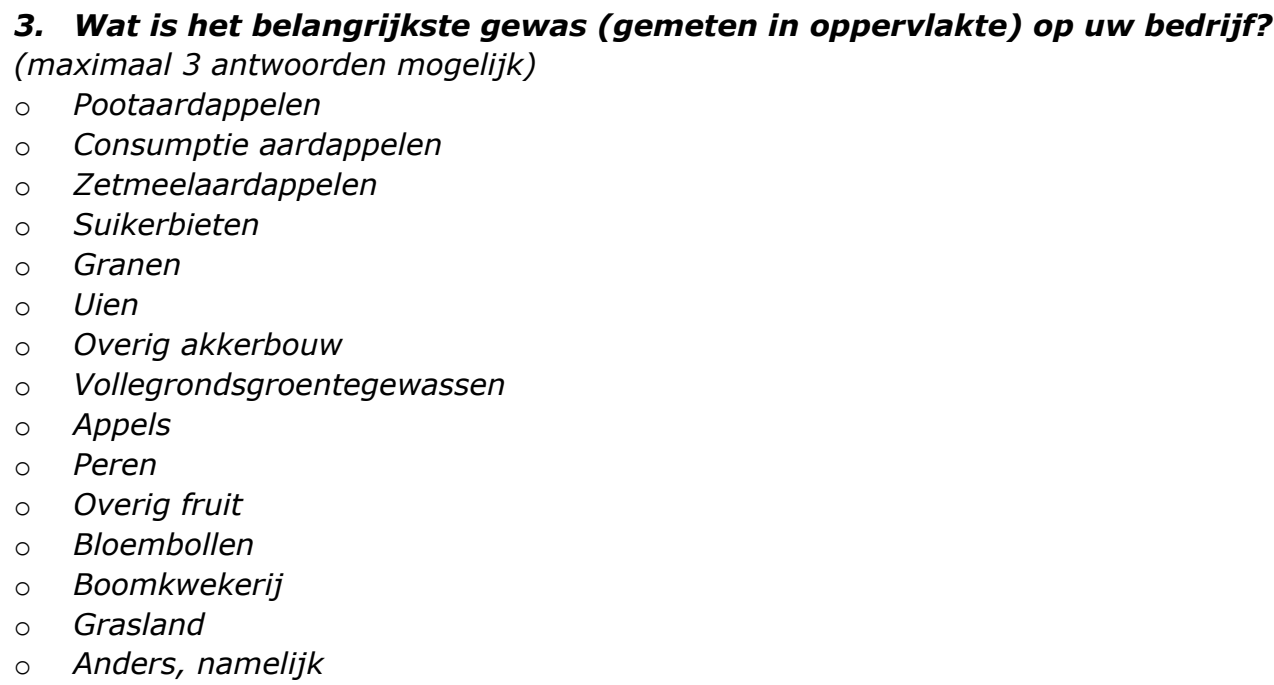

4. Welke grondsoort komt er voor op uw bedrijf?

(meerdere antwoorden mogelijk)

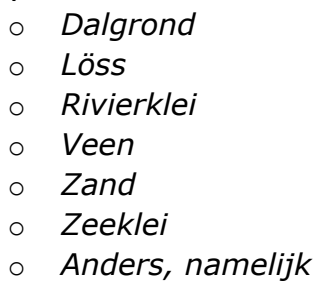

5. In welke provincie ligt de hoofdvestiging van uw bedrijf?
Drenthe
Flevoland
Friesland
Gelderland
Groningen
Limburg
Noord-Brabant
Noord-Holland
Overijssel
Utrecht
Zeeland
Zuid-Holland

\section{Wat is uw geboortejaar?}

(rolbar met mogelijke jaartallen vanaf 1920.)

7. Heeft $u$ in $\mathbf{2 0 1 5}$ een brede weersverzekering afgesloten?

- Ja (Ga verder naar vraag 8)

- Nee (Ga verder naar vraag 11) 


\section{Heeft $u$ in onderstaande jaren een brede weersverzekering afgesloten?}

Reden voor afsluiten brede weersverzekering

\section{Hoe belangrijk waren onderstaande argumenten om een brede weersverzekering af} te sluiten?

1 = heel onbelangrijk

2 = redelijk onbelangrijk

3 = neutraal (onbelangrijk noch belangrijk)

4 = redelijk belangrijk

5 = heel belangrijk

Nvt / geen mening

\section{Argumenten}

Zelf grote gewasschade gehad

Kans op schade door het weer op mijn bedrijf is groot

Wijziging in uitbetalen premie door de overheid

(RVO.NL) op de afgesloten weersverzekering

Enige manier om vanuit de overheid bij gewasschade

nog een tegemoetkoming te krijgen in de geleden

schade

Aantrekkelijke voorwaarden

Aantrekkelijke premie

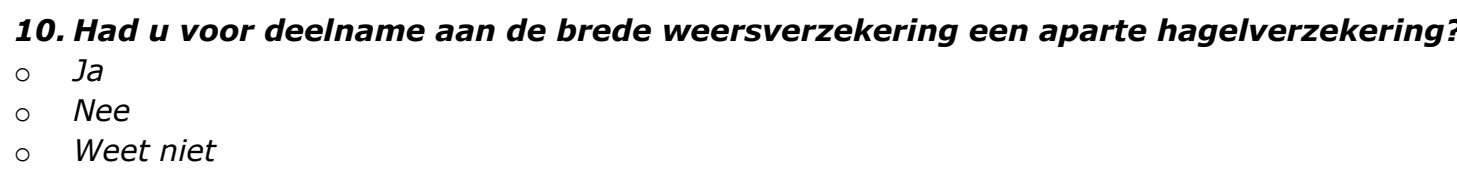

Reden voor niet afsluiten brede weersverzekering

\section{Hoe belangrijk waren onderstaande argumenten voor u om geen brede weersverzekering af te sluiten?}

1 = heel onbelangrijk

2 = redelijk onbelangrijk

3 = neutraal (onbelangrijk noch belangrijk)

4 = redelijk belangrijk

5 = heel belangrijk

Nvt / geen mening

\section{Argumenten}

Kans op schade door het weer op mijn bedrijf is klein

Continuïteit van mijn bedrijf komt in geen geval in gevaar

Ik heb alternatieve maatregelen getroffen (zoals bijv. afzonderlijke verzekering, hagelnetten, meerdere locaties)

Dekking van de verzekering is te beperkt

Eigen risico is te hoog

Mijn bedrijf voldoet niet aan de voorwaarden van de verzekering

Premie is te hoog 
Ik weet te weinig af van de mogelijkheden om een brede weersverzekering af te sluiten

De tegemoetkoming in de premie (vergoeding voor een

deel van de verzekeringspremie) is niet duidelijk

Mijn verwachting is dat bij grote calamiteiten de

overheid noodsteun zal verlenen

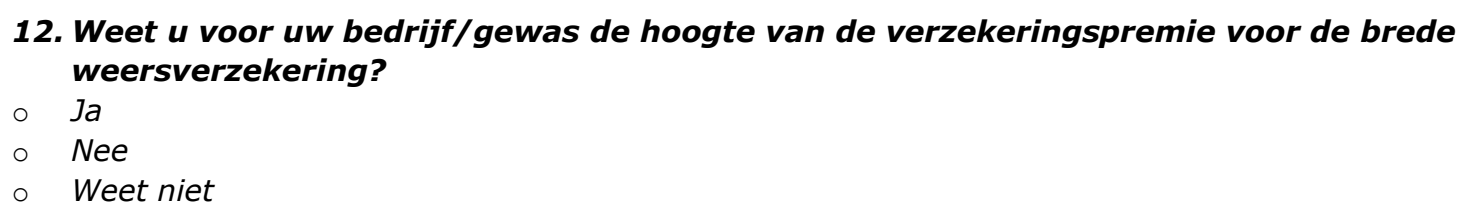

\section{Heeft u een hagelverzekering afgesloten?}

Ja

Nee

Weet niet

Perceptie en risicohouding

\section{In welke mate zijn onderstaande factoren voor uw bedrijf risicovol?}

$$
\begin{aligned}
& 1=\text { niet risicovol } \\
& 2=\text { licht risicovol } \\
& 3=\text { matig risicovol } \\
& 4=\text { erg risicovol } \\
& 5=\text { zeer risicovol }
\end{aligned}
$$

$\begin{array}{lllll}\text { Factor } & 1 & 2 & 3 & 5 \\ \text { Droogte } & & & \\ \text { Hagel } & & & \\ \text { Regen } & & & \\ \text { Sneeuw } & & & \\ \text { Vorst } & & & \end{array}$

\section{Geef aan in welke mate u het eens bent met de volgende stellingen}

1 = helemaal mee oneens

2 = oneens

3 = neutraal (noch oneens noch eens)

$4=$ eens

5 = helemaal mee eens

\section{Stelling}

1

2

Ik hou van experimenteren met nieuwe productiemethoden Ik geef de voorkeur aan zekerheid boven onzekerheid Ik benut meer kansen dan anderen

Ik durf meer risico's te nemen dan mijn collega's

Ik moet bereid zijn om risico's te nemen om succesvol te zijn

Nieuwe werkwijzen moeten zich eerst bewijzen bij collega's

voordat ik ze ga toepassen

Op het bedrijf ben ik risicomijdend

Ik ben in de financiële positie dat ik risico's kan nemen

Ik gok erop dat ik geen grote schades zal lijden

Behoefte aan brede weersverzekering en randvoorwaarden

16. Vindt u het van belang dat er ook na 2020 een brede weersverzekering blijft in de huidige vorm, dus met tegemoetkoming in de premie door de overheid (subsidie)?

- Ja, afhankelijk van de voorwaarden en kosten

- Ja, want ik verwacht dat de overheid niet meer op een andere manier bijspringt

- Nee, want ik verwacht dat de overheid betaalt in het geval van grote weersschaden

Nee, want het behoort tot het normale bedrijfsrisico

Nee, andere reden

- Weet niet 
17. Ziet u voor de toekomst een rol weggelegd voor de overheid bij het verzekeren tegen weerscalamiteiten?

(maximaal 2 antwoorden mogelijk)

- Nee

- Ja, door premiesubsidie

- Ja, door deze verzekering vrij te stellen van assurantiebelasting

- Ja, door garantstelling bij rampen

- Ja, door het fiscaal reserveren van de bedrijfswinst voor schade mogelijk te maken

- Ja, anders namelijk

Tot slot

Als u nog opmerkingen over deze enquête heeft of suggesties m.b.t. brede weersverzekeringen, dan kunt u die hieronder kwijt.

\section{Opmerkingen:}




\section{Bijlage 4 Geïnterviewde personen}

\section{Verzekeraars}

Achmea: Willem Snoeker

AgriVer: Marien Boersma

OFH: Gert Jan van Dijk

Vereinigte Hagel: Jan Schreuder

\section{Landbouworganisaties}

ZLTO: Adrie Bossers

NAV: Kees van Dijk

NFO: Siep Koning

\section{RVO.NL}

Carla Overgaauw

Carel Vrehe 
Wageningen Economic Research Postbus 29703

2502 LS Den Haag

T 0703358330

Ecommunications.ssg@wur.nl

www.wur.nl/economic-research

Wageningen Economic Research RAPPORT

2016-070
De missie van Wageningen University \& Research is 'To explore the potential of nature to improve the quality of life'. Binnen Wageningen University \& Research bundelen Wageningen University en gespecialiseerde onderzoeksinstituten van Stichting Wageningen Research hun krachten om bij te dragen aan de oplossing van belangrijke vragen in het domein van gezonde voeding en leefomgeving. Met ongeveer 30 vestigingen, 5.000 medewerkers en 10.000 studenten behoort Wageningen University \& Research wereldwijd tot de aansprekende kennisinstellingen binnen haar domein. De integrale benadering van de vraagstukken en de samenwerking tussen verschillende disciplines vormen het hart van de unieke Wageningen aanpak. 



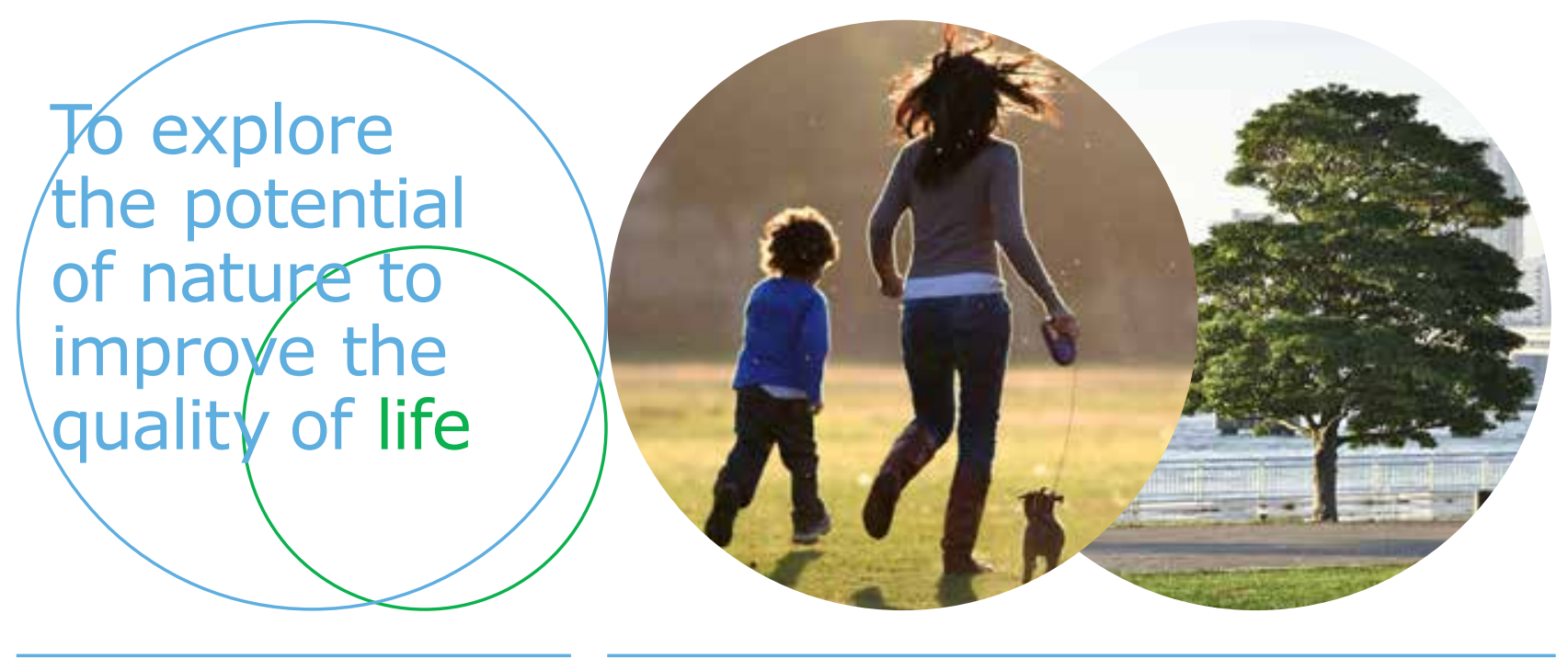

Wageningen Economic Research Postbus 29703

2502 LS Den Haag

E communications.ssg@wur.nl

$\mathrm{T}+31(0) 703358330$

www.wur.nl/economic-research

Rapport 2016-070

ISBN 978-94-6257-934-7
De missie van Wageningen University \& Research is 'To explore the potential of nature to improve the quality of life'. Binnen Wageningen University \& Research bundelen Wageningen University en gespecialiseerde onderzoeksinstituten van Stichting Wageningen Research hun krachten om bij te dragen aan de oplossing van belangrijke vragen in het domein van gezonde voeding en leefomgeving. Met ongeveer 30 vestigingen, 5.000 medewerkers en 10.000 studenten behoort Wageningen University \& Research wereldwijd tot de aansprekende kennisinstellingen binnen haar domein. De integrale benadering van de vraagstukken en de samenwerking tussen verschillende disciplines vormen het hart van de unieke Wageningen aanpak. 